\title{
Turnover Rates and Organizational Performance: A Meta-Analysis
}

\author{
Tae-Youn Park \\ Vanderbilt University
}

\author{
Jason D. Shaw \\ University of Minnesota
}

\begin{abstract}
The authors conducted a meta-analysis of the relationship between turnover rates and organizational performance to (a) determine the magnitude of the relationship; (b) test organization-, context-, and methods-related moderators of the relationship; and (c) suggest future directions for the turnover literature on the basis of the findings. The results from 300 total correlations $(N=309,245)$ and 110 independent correlations $(N=120,066)$ show that the relationship between total turnover rates and organizational performance is significant and negative $(\rho=-.15)$. In addition, the relationship is more negative for voluntary $(\rho=-.15)$ and reduction-in-force turnover $(\rho=-.17)$ than for involuntary turnover $(\rho=-.01)$. Moreover, the meta-analytic correlation differs significantly across several organization- and context-related factors (e.g., types of employment system, dimensions of organizational performance, region, and entity size). Finally, in sample-level regressions, the strength of the turnover rates-organizational performance relationship significantly varies across different average levels of total and voluntary turnover rates, which suggests a potential curvilinear relationship. The authors outline the practical magnitude of the findings and discuss implications for future organizationallevel turnover research.
\end{abstract}

Keywords: meta-analysis, organizational performance, turnover rates

The relationship between turnover rates and organizational performance has been examined from various disciplinary perspectives, including organizational psychology, sociology, economics, and human resource management. Perhaps because interest in the topic is highly dispersed, the research literature has provided little integration; indeed, some extant results seem conflicting. For example, some studies have shown a negative relationship between turnover rates and organizational outcomes such as sales (e.g., Baron, Hannan, \& Burton, 2001; Batt, 2002; Huselid, 1995), customer service (e.g., Kacmar, Andrews, Van Rooy, Steilberg, \& Cerrone, 2006; Plomondon et al., 2007), profit (e.g., McElroy, Morrow, \& Rude, 2001; Van Iddekinge et al., 2009), and return on assets (e.g., Messersmith, Guthrie, \& Ji, 2010; Shen \& Cannella, 2002). But many studies have failed to find negative relationships (e.g., Arthur, 1994; Guthrie, 2001; Kesner \& Dalton, 1994; Shaw, Duffy, Johnson, \& Lockhart, 2005; Wagner, Pfeffer, \& O’Reilly,

This article was published Online First December 17, 2012.

Tae-Youn Park, Owen Graduate School of Management, Vanderbilt University; Jason D. Shaw, Carlson School of Management, University of Minnesota.

We thank seminar participants at Cornell University, the Hanken School of Economics, Tsinghua University, Hong Kong Polytechnic University, Concordia University, Auburn University, Technical University Munich, and the London School of Economics for constructive comments on other versions of this article. We also thank Jacqueline Thompson for editorial assistance.

Correspondence concerning this article should be addressed to TaeYoun Park, Owen Graduate School of Management, Vanderbilt University, 401 21st Avenue South, Nashville, TN 37221. E-mail: TaeYoun.Park@ owen.vanderbilt.edu
1984; Zimmerman et al., 2005), and some have even reported significantly positive associations (e.g., Keck, 1997; Virany, Tushman, \& Romanelli, 1992).

As momentum in this area grows, three recent reviews have described the state of organizational-level turnover literature as "much less well developed" than individual-level turnover research (Shaw, 2011, p. 187), as an "area of inquiry [that] merits further investigation" (Holtom, Mitchell, Lee, \& Eberly, 2008, p. 252), and as an area where "much remains to be learned" (Hausknecht \& Trevor, 2011, p. 379). As a starting point for future research, it is worthwhile to consider and summarize what the existing empirical literature tells us about turnover rates and organizational performance. Practitioners may also benefit from a quantitative summary to judge whether they have correctly or over-stated their intuitive concerns about turnover's potential costs and benefits. Our purpose, therefore, is to perform a meta-analysis of the relationship between turnover rates and organizational performance to (a) determine the magnitude of the relationship between these variables; (b) test organization-, context-, and methods-related moderators of the relationship; and (c) suggest future directions for the turnover literature on the basis of the meta-analytic findings.

\section{Theoretical Perspectives on the Turnover Rates and Organizational Performance Relationship}

The relationship between turnover rates and organizational performance has been examined, in general, under three alternative views: (a) turnover rates at any level disrupt organizational performance (e.g., Osterman, 1987); (b) turnover rates are most disruptive at low- to moderate-levels, but the disruptive effects are attenuated at high levels (e.g., Price, 1977); and (c) turnover rates 
enhance organizational performance at low- to moderate-levels, but disrupt performance at high levels (e.g., Abelson \& Baysinger, 1984). We summarize the theoretical explanations for these views below.

\section{Model 1: Linear Negative Relationship View From Human and Social Capital Theories}

Human and social capital theories suggest that turnover rates at any levels hurt organizational performance. Human capital theory proposes that more experienced employees perform better because they accumulate the knowledge and skills (i.e., human capital) necessary to perform the job (Strober, 1990). From this view, when experienced employees leave, an organization suffers because it loses stored/accumulated human capital (Osterman, 1987; Strober, 1990). Organizations may replace employees who leave, but time must pass before replacements accumulate similar levels of human capital. Moreover, turnover generates additional human resource management costs such as recruitment, selection, and training expenses.

Similar to human capital theory, social capital theory suggests that turnover is costly because it depletes social capital- "a resource reflecting the character of social relations within the organization, realized through members' levels of collective goal orientation and shared trust" (Leana \& Van Buren, 1999, p. 540). Increases in turnover rates disrupt an organization's social fabric and its operational and collective functions (Dess \& Shaw, 2001; Shaw, Duffy, et al., 2005). In addition, turnover engenders additional newcomer socialization costs. Human and social capital theories focus on increases in turnover rates and suggest that turnover rates are linearly and negatively related to organizational performance (Shaw, Gupta, \& Delery, 2005).

This human and social capital theory perspective appears to have the most empirical support in the literature. For example, research has found increases in turnover rates to be negatively related to customer satisfaction (Morrow \& McElroy, 2007), sales growth (Batt, 2002), return on equity (Cannella \& Hambrick, 1993), and profit (Kacmar et al., 2006). In addition, Van Iddekinge et al. (2009) tested the causal direction of the turnover ratesperformance relationship and showed that retention rates (the inverse of turnover rates) significantly and positively influenced the change in unit profitability over time.

In contrast, other theoretical and empirical extensions in the turnover literature provide a more nuanced picture of the turnover rates-organizational performance relationship; in particular, they suggest a curvilinear relationship. From these views, many previous empirical studies are limited because they fail to address possible curvilinearity. The form of the curvilinear relationship is disputed, however, depending on the root of theoretical viewpoints, whether from organizational learning and control theories or from cost-benefit theories. These two alternative models are discussed below.

\section{Model 2: Attenuated Negative Relationship View From Organizational Learning and Control Theories}

Sharing some common elements of human capital theory, the organizational learning and control theories suggest an attenuated negative relationship between turnover rates and organizational performance. On average, organizations with low turnover rates have accumulated much human capital. When employees leave, replacement employees cannot equal the lost human capital until much time passes. In contrast, organizations with high turnover rates have workforces that lack accumulated human capital; replacements can quickly build equivalent capital and rapidly negate human capital losses. In addition, continuous workforce replacement becomes routine, so marginal turnover costs are reduced (Shaw, Duffy, et al., 2005; Shaw, Gupta, \& Delery, 2005). From this viewpoint, an increase in turnover rates from low-to-moderate levels are more disruptive to organizational performance than an increase in turnover rates from moderate-to-high levels (Price, 1977; Shaw, Gupta, \& Delery, 2005).

Several studies have found evidence supporting the attenuated negative relationship. Shaw, Gupta, and Delery (2005) studied the trucking and concrete pipe industries and found that the relationship between voluntary turnover rates and organizational performance was strongly negative initially but attenuated at higher turnover levels. Similarly, Ton and Huckman (2008), in a sample of bookstores, found severe performance decreases as turnover rates went from low to moderate levels, but the relationship was attenuated as the rates increased from moderate to high levels. Interestingly, Alexander, Bloom, and Nuchols (1994) hypothesized an inverted-U-shaped relationship, which we describe below, but their empirical results provided some support for the attenuated negative relationship pattern.

\section{Model 3: Inverted-U Relationship View From Cost-Benefit Theories}

In contrast to the attenuated negative relationship, another curvilinear view on the turnover rates-performance relationship predicts that turnover rates are beneficial at low levels but costly at high levels. Specifically, these cost-benefit theories propose that turnover conveys greater benefits than costs at low to moderate turnover levels, but costs outweigh benefits at moderate to high levels where the turnover rates-organizational performance relationship becomes an inverted-U (Abelson \& Baysinger, 1984; Dalton \& Todor, 1979; Staw, 1980).

According to this perspective, some turnover benefits organizations by reducing compensation costs, revitalizing the workforce, and sorting out poor performers. Turnover reduces compensation costs related to base pay, vacation, sick leave, and insurance premiums (Alexander et al., 1994; Jeswald, 1974). In addition, turnover revitalizes organizations by introducing newcomers who bring current knowledge and skills (Alexander et al., 1994), reducing employee homogeneity, and increasing the diversity of ideas (Schneider, Goldstein, \& Smith, 1995). Moreover, turnover can eliminate poor performers and misfits who disrupt the organization's culture and values (Abelson \& Baysinger, 1984; Dalton $\&$ Todor, 1979). Hence, an optimal turnover rate is found at the point where benefits maximally exceed the costs. Specifically, at low to moderate levels where benefits are greater than costs, increased turnover rates can contribute to organizational performance, but as rates rise beyond moderate levels, they have negative effects.

Several studies have examined the inverted-U-shaped relationship between turnover rates and organizational performance, but the literature provides very little supportive evidence. Glebbeek 
and Bax (2004) found a curvilinear form, but the relationship failed to conform to the predicted inverted-U shape; rather performance peaked at very high turnover rates. Siebert and Zubanov (2009) tested the inverted-U hypothesis, but their results failed to support the curvilinear relationship clearly (Shaw, 2011). The strongest evidence is found in Meier and Hicklin's (2007) study; using a sample of Texas school districts, they found that low levels of district-level turnover rates were positively related to district SAT and ACT scores, but the relationship was negative at higher levels (i.e., an inverted-U-shaped relationship).

\section{Organization- and Context-Related Moderators of the Relationship Between Turnover Rates and Organizational Performance}

Researchers have identified several factors that influence the relationship between turnover rates and organizational performance (Hausknecht \& Trevor, 2011; Shaw, 2011). We examine three major organization- and context-related factors that possibly moderate the relationship: (a) turnover rate types, (b) dimensions of organizational performance, and (c) organizational contexts and characteristics (e.g., employment system, entity size, industry, and region).

\section{Turnover Rate Types}

Turnover researchers have often operationalized turnover rates as the number of departing employees divided by the total number of employees (e.g., Arthur, 1994; Guthrie, 2001). This operationalization, which we call total turnover rates, omits employees' reasons for leaving. A more refined approach is distinguishing voluntary and involuntary turnover rates based on reasons for leaving; voluntary turnover rates refer to the proportion of employee departure initiated by employees (e.g., resignations), and involuntary turnover rates refer to the proportion of departure initiated by organizations (e.g., firings, discharges, dismissals, terminations; Shaw, Delery, Jenkins, \& Gupta, 1998). Voluntary turnover rates include resignations for higher wages, career opportunities, further education, and job dissatisfaction for example (Campion, 1991) and exclude discharges, retirements, transfers, and promotions (Batt, 2002). In contrast, involuntary turnover rates include resignations caused, for example, by failure to meet expectations and expired employment contracts (Campion, 1991; McElroy et al., 2001). Reduction-in-force (RIF) turnover (downsizing) is a separate category because "no replacement employees are planned and the departing employees are presumed to have been at least minimally competent" (McElroy et al., 2001, p. 1295). ${ }^{1}$

Researchers have often suggested that voluntary and involuntary turnover have different consequences (e.g., Hausknecht \& Trevor, 2011; Holtom et al., 2008; Shaw, 2011). Highly skilled, highperforming employees may be more likely to leave voluntarily because they have external employment opportunities (Trevor, 2001). For an organization, voluntary quits are often surprising and unmanageable (Shaw et al., 1998). Thus, voluntary turnover rates are likely to be negatively related to organizational performance.

In contrast, the relationship between involuntary turnover rates and organizational performance has long been assumed to be positive because organizations choose to discharge employees for individual performance deficiencies or other behavioral problems (Holtom et al., 2008). Assuming that poor performers are properly replaced with better performers, the removal of poor performers should be associated with better organizational performance (Dalton, Todor, \& Krackhardt, 1982; Hollenbeck \& Williams, 1986). In addition, this sorting effect may help remedy poor hiring decisions (Shaw et al., 1998), and maintain performance-oriented norms among remaining employees (Trevino, 1992). Some researchers have, however, recently questioned the presumed positive relationship and have proposed that the involuntary turnover rates and organizational performance have a negative relationship instead. Hausknecht and Trevor (2011) argued that high involuntary turnover rates "may have little to do with the employee movement per se (which is the foundation for the voluntary turnover rate hypothesis) but may instead simply reflect a lowquality workforce and the subsequent poor performance that this group is expected to provide" (p. 369). From a somewhat different view, Batt and Colvin (2011) suggested that both voluntary and involuntary turnover disrupt organizational performance because both incur recruitment and training costs and disrupt social connections. Although their data failed to fully support the argument, the relationship was in a direction consistent with their expectation: in the customer satisfaction regression model the coefficient for involuntary turnover rates was negative although not statistically significant. In sum, the literature has predominantly focused on a positive relationship between involuntary turnover rates and organizational performance, but recent attention reports a negative relationship.

Views on the relationship between RIF turnover rates and organizational performance have also been equivocal. RIF objectives are often to enhance productivity and profitability by eliminating redundant or unnecessary jobs and employees (Dewitt, 1998; Freeman \& Cameron, 1993). Thus, RIF proponents argue that RIF reduces organizational slack and operating costs, and enhances efficiency and profitability (e.g., Brookman, Chang, \& Rennie, 2007; Cascio \& Young, 2003; Chalos \& Chen, 2002; Palmon, Sun, \& Tang, 1997; Yu \& Park, 2006). Yet, opponents argue that RIF hurts organizational performance because it increases employment instability and voluntary turnover rates among those remaining (Trevor \& Nyberg, 2008). In addition, RIF disrupts social capital (Pfeffer, 1998) and engenders behavioral rigidity and risk aversion (Cameron, Whetton, \& Kim, 1987; Cascio, 1993), which overturn the temporal benefits (Hallock, 1998). Recently, Datta, Guthrie, Basuil, and Pandey (2010) conducted a thorough qualitative review of the RIF turnover rates and organizational performance relationship and suggested that, despite somewhat equivocal empirical findings, the overall relationship was likely negative.

In sum, based on the existing literature, we can reasonably expect that voluntary turnover rates will be negatively related to organizational performance. Views are contradictory about involuntary and RIF turnover effects, but recent qualitative reviews

\footnotetext{
${ }^{1}$ Although many organizations classify turnover as voluntary, involuntary, and RIF turnover, some turnover types are not clearly voluntary or involuntary, such as retirement, health problems, pregnancy, and separation by mutual agreement. Accordingly, the turnover literature may benefit from the development and use of alternative classifications turnover rate types.
} 
suggest that RIF turnover rates and organizational performance will also be negatively related.

\section{Dimensions of Organizational Performance}

The broad concept of organizational performance comprises many operationalizations (e.g., P. J. Richard, Devinney, Yip, \& Johnson, 2009). Turnover researchers have often categorized performance into proximal (workforce-related outcomes) and distal (financial, market, and shareholder return) outcomes. Turnover research has most often examined workforce-related performance such as productivity, partly because human and social capital theory foundations can be most directly applied to those proximal outcomes (Dess \& Shaw, 2001; Osterman, 1987; Shaw, Gupta, \& Delery, 2005). Financial and market-oriented organizational performances have been regarded as distal outcomes because several other factors, such as general economic conditions, may dilute the direct turnover effects. For example, Kacmar et al. (2006) proposed a turnover-efficiency-profit model showing that turnover reduces restaurant profits by lengthening customer wait-time. As such, the most proximal measures of organizational performance might be those related to employee interactions and attitudes such as customer satisfaction and absenteeism. Time must pass before the cycle of customer service and employee attitude changes affect customer spending, unit-level workforce productivity, and eventually unit profits. Indeed, the literature has generally assumed, and some evidence has found, that turnover rates will be more strongly related to workforce-related measures than financial measures (e.g., Huselid, 1995; Kacmar et al., 2006; Shaw, Gupta, \& Delery, 2005). In this meta-analysis, we categorize the organizational performance dimensions into three broad categories - the most proximal, moderately proximal, and distal-and we expect that the turnover rates-performance relationship will be strongest for the most proximal measures (e.g., customer satisfaction, employee work attitudes, absenteeism), modest for moderately proximal measures (e.g., quality, safety, workforce productivity), and weak for distal ones (e.g., financial performance).

\section{Organizational Context and Characteristics}

The relationship between turnover rates and organizational performance may be different depending on the context or environment in which turnover occurs (e.g., Arthur, 1994; Batt \& Colvin, 2011; Shaw, Gupta, \& Delery, 2005). The organizational literature frequently mentions several contextual factors as potentially important to the turnover rates-performance relationship. Next, we briefly discuss these factors: employment systems, entity size, industries, and region.

Organizations use different employment systems in their approaches to human resource management. The strategic human resource management literature (e.g., Arthur, 1992, 1994; Shaw, Gupta, \& Delery, 2005) suggests that organizations shape employee behaviors and work attitudes using two distinctive employment systems: (a) primary employment systems that forge psychological links between organizational and employee goals (also called commitment systems), and (b) secondary employment systems that emphasize labor cost reduc- tion, efficiency improvement, and employee compliance with specified rules and procedures (also called control systems). The two employment systems often coexist in an organization (Lepak \& Snell, 1999) depending on the employees (Bamberger \& Meshoulam, 2000; Delery \& Shaw, 2001; Lepak \& Shaw, 2008; Lepak, Taylor, Tekleab, Marrone, \& Cohen, 2007; Siebert \& Zubanov, 2009). For example, full-time managers are more appropriately managed under primary or commitmentbased employment systems because they need less supervision and have more discretion in their job tasks. Part-time employees are typically managed under secondary or control-based employment systems because they perform routine tasks with clearly specified rules and procedures.

Researchers have often suggested that turnover rates more strongly and negatively affect organizational performance under primary employment systems than under secondary employment systems (Arthur, 1994; Guthrie, 2001). Because organizations invest more in pay, training, benefits, and socialization programs for employees under primary systems, their turnover is more costly in terms of lost investments and human and social capital depletion. In contrast, organizations select secondary system employees less carefully and invest less in their services, so their departure depletes less human and social capital (Shaw, Dineen, Fang, \& Vellella, 2009). For example, in a sample of retail chain employees, Siebert and Zubanov (2009) compared full-time employees under a commitment system and part-time employees under a control system and found that turnover rates were more strongly and negatively related to sales when the turnover occurred in commitment systems.

Executives strongly influence organizational performance because they make important strategic decisions (viz., upper echelon theory; Hambrick \& Mason, 1984). Departures among executive team members may be the most strongly related to organizational performance because of lost information necessary for strategic decisions and altered executive team composition (Virany et al., 1992; Wagner et al., 1984). Executive turnover also incurs significant human resource management costs because executives are managed under distinctive and elaborate employment systems designed to carefully select, motivate, and retain them (e.g., Gerhart \& Rynes, 2003). Thus, in our analyses, we separate executiveor top-management-team turnover rates from turnover rates of employees in primary and secondary systems. To summarize, we expect that turnover rates and organizational performance will be more strongly and negatively related in samples managed by primary and executive employment systems than in those managed by secondary employment systems.

The literature holds two contrasting views about the moderating effects of entity size on turnover rates-performance relationships. Some have proposed that larger organizations will show a weakened negative relationship because larger groups can buffer turnover's disruptions (e.g., Green, Anderson, \& Shivers, 1996; Kozlowski \& Bell, 2003). In addition, equivalent turnover rates will inflict less damage on larger organizations because they can better withstand the same proportional information losses (Carley, 1992). Others, in contrast, have argued that larger organizations will show stronger negative turnover rates-performance relationships because smaller entities can handle socialization and adjustment processes more efficiently (Hausknecht, Trevor, \& Howard, 2009). 
Thus, entity size is an important moderator, but the direction and magnitude of the effect remains unknown.

Moreover, we expect industry to moderate the turnover rates and organizational performance relationship. Strategic human resource management and human capital theory literature suggest that the importance of human capital varies across industries because organizations adopt different technology and work structures depending on the characteristics of their industries (e.g., Datta, Guthrie, \& Wright, 2005; Dess \& Shaw, 2001). For example, Datta et al. (2005) argued that in industries with high levels of capital intensity (e.g., manufacturing), organizational decision makers place greater emphasis on leveraging investments in technology, equipment, and physical resources and place relatively less emphasis on human capital development. In other industries (e.g., health care, hospitality) employees play a central role in the functioning of the organization and therefore human capital losses through high turnover rates may have substantial negative effects on performance. As such, it is reasonable to expect that the relationship between turnover rates and organizational performance will be stronger in industries where the leveraging of human capital is more important to organizational performance than in industries with high capital intensity. In support of this line of reasoning, Shaw, Park, and Kim (2012) found that the negative relationship between turnover rates on organizational performance were exacerbated among organizations that invested heavily in human capital (see also, Arthur, 1994; Guthrie \& Datta, 2008).

Last, we anticipate that region may moderate the relationship between turnover rates and organizational performance. Labor market policies, regulations, and human resource management practices vary dramatically across regions of the world (Ahmad \& Schroeder, 2003; Pfeffer, 1998). In particular, there are considerable differences in the rigidity of labor markets across regions. European labor markets tend to be less flexible than those in North America and Asia because of strict employment policies, heavy regulation, and emphasis on collective bargaining agreements. These characteristics likely not only reduce the frequency and the variance in voluntary and involuntary turnover rates-serving to reduce the bivariate relationship-but may also increase the predictability of turnover. The ability to plan and prepare for turnover events may lessen negative effects on organizational performance.

\section{Methods-Related Moderators of the Relationship Between Turnover Rates and Organizational Performance}

We also explore possible differences in the turnover rates and organizational performance relationship by using methods-related moderators. We identify potential upward/downward biases on the turnover rates-performance correlations caused by variance in methods rather than true theoretical variance. Specifically, we examine three research design factors (unit of analysis, data structure, and source of turnover rates information) and three publication factors (role of turnover rates, hypothesized relationship, and publication status) that possibly moderate the turnover ratesperformance relationship.

\section{Research Design}

Research design-related factors may moderate the relationship between turnover rates and performance, including (a) unit of analysis (unit-level vs. organization-level), (b) data structure (cross-sectional vs. lagged vs. panel), and (c) source of turnover rates information (organizational record vs. key information).

Shaw (2011) and Hausknecht and Trevor (2011) suggested that considering distinctions between cross-organization samples (with different policies, practices, and organizational forms) and crossunit samples (with similar policies, practices, and organizational forms) could potentially provide better understanding of the relationship between turnover rates and organizational performance. Cross-organization samples offer some advantages because the variation in turnover rates and organizational performance can be large, and such samples allow researchers to explore potential contextual moderators including industry dynamics (e.g., Guthrie \& Datta, 2008) and staffing and employment policy differences (e.g., Bamberger \& Philips, 1991; Lepak et al., 2007). In contrast to the cross-organization samples, cross-unit studies can be better for addressing causality issues by holding certain threats to internal validity constant (Shadish, Cook, \& Campbell, 2001), and by ensuring consistent definition and measurement of turnover rates. We make no specific prediction about which unit of analysis produces stronger turnover rates-performance correlations, but it would be informative to examine whether and how the unit of analysis moderates the relationship.

Another possible design-related moderator is data structure: cross-sectional, lagged, and panel data structures. Meta analytic summary using zero-order correlations fails to ensure causality. Reverse causality concerns might be relatively more serious when turnover rates and organizational performance are measured concurrently than when a time-lagged performance variable is used. Panel data are another possible data structure. For regression-based data analysis, panel data might advantageously address reverse causality because panel data allow researchers to control for potential confounding factors. In terms of correlations for metaanalysis, however, correlations from panel data are similar to the correlations from cross-sectional data because the convention in the literature is for researchers to report a single betweenorganization correlation. For example, Siebert and Zubanov (2009) analyzed data from 325 retail stores over a 5-year window $(1,625$ store years), but reported a single between-store correlation $(N=$ 325 ) of -.24 between the full-time turnover rates and store performance. This correlation-the association between turnover rates averaged across the years of the study and organizational performance averaged across the years of the study - is similar to a cross-sectional correlation, albeit over a longer time window.

Last, the source of turnover rates information is a potential research design-related moderator. Unit-level research often relies on archival sources and/or key informants. A concern about using key informants is that few people can accurately report organizational information such as turnover rates and organizational performance. In addition, informants with inadequate knowledge and low motivation to provide accurate data will damage the accuracy and reliability of organizational information (Delery \& Shaw, 2001). To examine the potential bias of using key information data (versus archival data), we examine the source of turnover rates information for its possible moderation effects. 


\section{Publication Moderators}

Standard practice for reporting meta-analysis results includes exploring potential publication-related moderators. When readily available studies differ from results of all other research in an area, readers and reviewers may draw wrong conclusions (Rothstein, Sutton, \& Borenstein, 2005). Thus, we examine possible publication-related moderators, including the role of turnover rates (independent vs. dependent vs. moderator vs. mediator vs. control variables), hypothesized relationships (hypothesized vs. not hypothesized), and publication status (top journal vs. non-top journal). Note that we have no specific expectations regarding the research design-related moderators; we explore them for their effects on the pattern of the turnover rates and organizational performance relationship.

\section{Summary}

To summarize, we use a meta-analytic review to examine the relationship between turnover rates and organizational performance. Based on the literature's theorizing and assumptions, we also outline several potential moderators of the relationship including turnover rate types, dimensions of organizational performance, employment systems, entity size, industry, and region. In addition, following prior researchers (e.g., Judge, Thoresen, Bono, \& Patton, 2001), we also identify and test several other methods-related factors as potential moderators. Next, we report our criteria for inclusion in the meta-analysis and the results.

\section{Method}

\section{Literature Search}

We extensively searched the literature to identify studies published before or during February 2012. First, we searched the ISI Web of Knowledge, PsycINFO, EBSCO, JSTOR, and PROQUEST databases using keywords such as turnover, quit, fire, discharge, layoff, slimming, resizing, rightsizing, retention, withdrawal, downsizing, performance, leaning-up, restructuring, productivity, re-engineering, and reduction-in-force. Second, we perused the reference sections of several narrative reviews (e.g., Datta et al., 2010; Hausknecht \& Trevor, 2011; Holtom et al., 2008; Shaw, 2011) to identify articles that our computer-based searches failed to capture. Third, we searched online for journals with turnover rates-performance studies still in press (e.g., Journal of Applied Psychology, The Academy of Management Journal, Strategic Management Journal, Organization Science, Personnel Psychology, Journal of Management, American Sociological Review, Quarterly Journal of Economics, The International Journal of Human Resource Management, and Human Resource Management). Fourth, we searched available conference programs for major associations including the Society for Industrial and Organizational Psychology, Strategic Management Society, and the Academy of Management. Fifth, we used e-mails to contact authors who have recently published in the areas of unit- and organization-level turnover, human resource management, and organizational performance. Our search yielded 255 articles and dissertations.

\section{Inclusion Rules and Sample}

First, we included empirical papers that reported correlations between turnover rates of any type and organizational performance dimensions of any type, and we excluded theoretical and review articles and papers that lacked the needed data for calculating correlations or effect sizes between turnover rates and organizational performance. Second, we included studies that tested relationships at the unit (facility) or organizational levels of analysis. We excluded studies that dealt with individual-level turnover issues, such as the relationship between individual performance and turnover probability (e.g., Boswell, Boudreau, \& Tichy, 2005; Hollenbeck \& Williams, 1986) and studies involving individuallevel turnover intent (e.g., Sheridan, 1985). Third, we included studies that used a rate or ratio measure for turnover or retention and excluded studies that used a dichotomous variable for turnover (e.g., Cascio, Young, \& Morris, 1997; Hallock, 1998; Yu \& Park, 2006). Fourth, we included studies that focused on turnover rates for employee groups (or all employees) and excluded organizational-level studies of chief executive officer (CEO) turnover or departures of single top executives (e.g., Puffer \& Weintrop, 1991). A complete list of the studies considered but excluded can be found in Appendix B.

We separated the articles into those that were complete (articles meeting the inclusion criteria and containing all the necessary information for the meta-analysis), incomplete (articles meeting the inclusion criteria but missing some needed information), and others (articles failing to meet one or more of the inclusion criteria). After isolating 62 incomplete studies, we e-mailed their 57 authors and received 31 responses. Among the responses, 20 authors were unable to provide more information for various reasons such as a confidentiality contract and lost, expired, outdated, or unavailable data, but 11 provided the information we requested, which yielded 25 additional correlations from 12 studies. As a result of these combined efforts, we obtained an initial data set of 371 turnover rates-performance correlations from 110 sources. The summary of the studies and samples used in the meta-analysis is found in Appendix A. To calculate the overall correlation, we coded all the possible zero-order correlations between turnover rates and organizational performance from each study. For example, we coded five correlations from Shaw, Gupta, and Delery's (2005) Study 2 (revenue per drive, accident frequency ratio, out-of-service percentage, operating ratio, and ROE). In addition, when a dimension of organizational performance was measured such that a higher value indicated lower performance (e.g., accident frequency ratio in Shaw, Gupta, \& Delery, 2005) we reversed the correlation by multiplying by -1 . However, some of the data points were non-independent because some correlations were computed from the same sample. Thus, correlations based on multiple measures of the same criterion in the same sample, such as return on surplus and return on assets (financial performance) in Riordan, Vandenberg, and Richardson (2005), were considered to be non-independent and were subsequently averaged to form a single data point. Likewise, data points based on temporally repeated measures of the same or similar criterion for the same sample (e.g., cash margin first year, cash margin second year; Chadwick, Hunter, \& Walston, 2004) were also considered to be non-independent and were subsequently averaged to form a single data point. If a study reported correlations for multiple dimensions 
of organizational performance (e.g., customer satisfaction and financial performance), those correlations were considered to be independent even though they were based on the same sample; therefore, they were retained as separate data points. In all, 75 non-independent correlations were averaged. These combined efforts provided 110 samples (from 104 papers) and 300 turnover rate-performance correlations, for a combined sample size of 309,245 .

Table 1 shows a stem-and-leaf display of the 300 correlations, showing that the correlations are fairly normally distributed with very few outliers.

\section{Organization- and Context-Related Moderators}

Turnover rate types were categorized as voluntary turnover, involuntary turnover, RIF, and total turnover. Voluntary turnover indicated the rate of employee-initiated separations (e.g., resignations), involuntary turnover was the rate of organization-initiated separations (e.g., dismissals), $R I F$ was the temporary or permanent separation rate of employees for business reasons (e.g., layoff, downsizing), and total turnover was the rate of total employee separations where the reasons were not included.

We classified organizational performance dimensions as workforce productivity, financial performance, overall performance, customer satisfaction, safety-related performance, employee work attitudes, and quality performance. Workforce productivity was employee-generated organizational performance including such measures as sales per employee, labor hours in a manufacturing company, and loan generation efficiency in a financial service company. Financial performance was cost-adjusted organizational performance, such as profit, return on investment (ROI), and return on assets (ROA). Customer satisfaction included customer service scores and customer service performance rating. Safety-related performance included measures such as accident rates and service violations. Employee work attitudes included measures such as absenteeism and grievance filings, and quality performance included measures such as defect density at semiconductor facilities. If the performance measures were omitted in any previously stated criteria, they were coded as overall performance, for example, for studies that included general measures of overall performance reported by key informants. In addition, we also categorized the organizational performance dimensions into three broad categories: the most proximal, moderately proximal, and distal performance. The most proximal performance included customer satisfaction, attitudes, and absenteeism; moderately proximal performance included quality, safety, and workforce productivity; and distal performance included financial performance.

Employment systems were identified as primary, secondary, executive, and all (Arthur, 1994; Bamberger \& Meshoulam, 2000; Delery \& Shaw, 2001; Siebert \& Zubanov, 2009). We coded a sample as a primary employment system when authors explicitly mentioned that their sample comprised key employee groups who can be trusted to use their discretion to carry out job tasks, such as bank branch directors (Gelade \& Ivery, 2003) and school teachers (Meier \& Hicklin, 2007). Secondary employment systems addressed periphery groups governed with specified rules and procedures, such as part-time crew members in Food-Co restaurants (Detert, Trevino, Burris, \& Andiappan, 2007), nursing assistants in nursing homes units (Donoghue, 2010), and customer-service employees in call centers (Batt, 2002). We coded executive employment systems if the study focused on executive- or topmanagement-team turnover and all if the turnover rate applied to all employees.

Entity size was coded as the average number of employees within the reported unit or organization. In addition, we classified each sample into one of 11 specific industry categories or as cross industry if the sample included multiple industries. Last, we identified region based on whether the sample came from North America, Europe, or Asia. We classified all region if a study used a sample of multiple units in different countries.

\section{Methods-Related Moderators}

Following previous meta-analysis study recommendations (e.g., Freund \& Kasten, 2012; Greenwald, Poehlman, Uhlmann, \& Banaji, 2009; Judge et al., 2001), we coded several other aspects of the research design and publication-related factors for additional exploratory moderator analyses.

Table 1

Stem and Leaf Display of 300 Correlations

\begin{tabular}{|c|c|}
\hline Stem & Leaf \\
\hline-.9 & \\
\hline-.8 & 0 \\
\hline-.7 & $8,5,3,1$ \\
\hline-.6 & 5 \\
\hline-.5 & $8,7,6,5,2,2,1,0,0$ \\
\hline-.4 & $9,9,7,7,7,6,6,5,5,5,3,2,2,1,0$ \\
\hline-.3 & $8,7,7,7,6,6,6,5,5,4,4,3,2,2,2,1,1,1,1,0,0$ \\
\hline-.2 & $9,9,9,8,7,7,6,5,5,5,5,5,5,5,4,4,4,4,4,4,4,4,3,3,3,3,3,3,3,2,2,2,2,2,1,1,1,1,1,0,0,0,0,0$ \\
\hline-.1 & $9,9,9,9,9,9,9,8,8,8,8,8,7,7,7,7,7,7,7,7,6,6,6,6,6,6,5,5,5,5,5,5,4,4,4,4,4,4,4,4,3,3,3,3,3,3,2,2,2,2,2,2,2,2,2,1,1,1,0,0,0,0,0,0,0,0,0,0$ \\
\hline-.0 & $9,9,9,9,9,9,9,9,9,9,9,8,8,8,8,8,8,8,7,7,7,7,7,7,7,7,7,7,6,6,6,6,6,6,5,5,5,5,5,5,5,5,5,5,5,4,4,4,4,4,4,4,4,3,3,3,3,3,3,3,3,2,2,2,2,2,2,2,2,1,1,1,1,1,1,1$ \\
\hline .0 & $0,0,0,0,0,0,1,1,1,1,1,1,1,1,2,2,3,3,3,4,4,5,5,5,5,5,6,6,6,6,7,7,8,8,8,8,9$ \\
\hline .1 & $0,0,0,0,1,2,2,2,2,3,3,5,5,5,6,7,9$ \\
\hline .2 & 1 \\
\hline .3 & $4,7,8$ \\
\hline .4 & $0,0,8$ \\
\hline .5 & \\
\hline
\end{tabular}


Unit of analysis was classified as organizational level or unit level. Unit level was further classified into units in one organization and units in multiple organizations. Data structure was crosssectional (concurrent measures of turnover rates and organizational performance), lagged (time separation between the measurement of turnover rates and organizational performance), and panel (correlations between average turnover rates across times and average organizational performance across times). If turnover rates were obtained from archival sources, the variable was coded as organizational record; if informants provided turnover rates, it was coded key informant. Role of turnover rates was based on its role in a given study: whether independent variable, dependent variable, mediator, moderator, or control. Moreover, when researchers predicted the relationship between turnover rates and organizational performance, we coded the sample as hypothesized; the rest we coded as not hypothesized. Last, we identified journal quality based on whether the study was published in a top-level journal (e.g., Journal of Applied Psychology, The Academy of Management Journal, Administrative Science Quarterly, Organizational Behavior and Human Decision Processes, Strategic Management Journal, Personnel Psychology, and Organization Science); publications appearing in other journals were coded as non-top journals.

\section{Meta-Analysis Procedure}

We assumed that sampling error and variability in the population of the correlations (unique differences in the set of true population correlations) caused the variability among turnover rates-performance correlations. Meta-analysis researchers recommend using a random effects model that assumes that sampling error causes variability between effect sizes (Aguinis, Dalton, Bosco, Pierce, \& Dalton, 2011; Erez, Bloom, \& Wells, 1996). Thus, rather than using a fixed effects model, we used a random effects model to consider heterogeneity among the studies. To perform the moderator analyses, we used a mixed-effects model, which allowed us to consider some excess individual correlation variability that the tested moderator fails to explain. Although conservative, these statistical models allowed us to extend our inferences to the universe of studies rather than restricting inferences to the studies included in the sample (Hedges \& Vevea, 1998; Lipsey \& Wilson, 2001). We weighted each correlation value by the sample size to ensure that correlations resulting from large sample sizes had greater weighting than correlations from smaller samples. Because reliability for turnover rates and organizational performance measures is not reported, we followed other macro-level meta-analysts (e.g., Bommer, Johnson, Rich, Podsakoff, \& MacKenzie, 1995; Dalton, Daily, Ellstrand, \& Johnson, 1998; Dalton, Daily, Johnson, \& Ellstrand, 1999) and used 0.8 for the reliability correction. When the same variable was measured at more than three time points (cf. Ployhart, Weekly, \& Ramsey, 2009; Van Iddekinge et al., 2009), we calculated the reliability estimate following Harter, Schmidt, and Hayes's (2002) suggestion (also see Scenario 23 of Schmidt \& Hunter, 1996). For example, in Ployhart et al.'s (2009) sample, reliability estimates were .89 for store productivity, .96 for adjusted controllable profit, and .72 for percentage of sales growth. In Van Iddekinge et al.'s (2009) sample, reliability estimates were .68 for turnover rates, .28 for customer service performance ratings, and .44 for profits.
We also calculated two estimates of variability- $80 \%$ credibility intervals and $95 \%$ confidence intervals. Confidence intervals provide an estimate of the variability around the estimated average correlation, and credibility intervals estimate variability of the individual correlations in the population of studies. Thus, a $95 \%$ confidence interval excluding zero indicates that one can be $95 \%$ confident that the average true score correlation is different than zero (fewer than $2.5 \%$ are zero or less, and a maximum of $2.5 \%$ are larger than the upper bound of the interval). An $80 \%$ credibility interval excluding zero indicates that at least $80 \%$ of the correlations reported are different than zero. Thus, generalizability can be inferred if the credibility interval does not include zero. In addition, we calculated the percentage variance explained (\%VE) to examine Hunter and Schmidt's (2004) 75\% rule: A search for moderators is warranted if artifacts can explain less than $75 \%$ of the observed variance in observed correlations. Furthermore, we conducted homogeneity analysis (Lipsey \& Wilson, 2001), which tests whether it is reasonable to assume that all effect sizes are estimating the same population mean. In particular, we used the $Q$ statistic, which indicates the level of variance across study results relative to the sampling error variance (Hedges \& Olkin, 1985), and generates a decision rule specifying whether a statistically significant level of variability exists in correlation coefficients across studies. The $Q$ test is analogous to analysis of variance; calculating the categorical models results in the between-group goodness-of-fit statistic $Q_{B}$, which has an approximate chi-square distribution with $g-1$ degrees of freedom, where $g$ is the number of groups, and the within-groups goodness-of-fit statistic $Q_{W}$, which has an approximate chi-square distribution with $k-1$ degrees of freedom, where $\mathrm{k}$ is equal to the number of correlations in the group (Field, 2001; Hedges \& Olkin, 1985; Lipsey \& Wilson, 2001).

\section{Results}

Table 2 shows the analysis of the relationship between turnover rates and organizational performance using the available correlations.

\section{Full Sample Results}

The top panel of Table 2 shows the meta analysis results using all available independent correlations $\left(k_{\text {corr }}=300 ; N=309,245\right)$. The average corrected correlation between turnover rates and organizational performance across all studies was negative $(\rho=$ -.15 ) and a $95 \%$ confidence level did not include zero $(95 \% \mathrm{CI}$ $[-.16,-.13])$. However, the corrected correlation showed large variance; the sampling error and measurement error accounted for $67.21 \%$; the credibility interval was rather large (-.33 to .04); and the homogeneity of effect sizes tests were significant across the analyses $(Q=4,358.28, p<.01)$. This justifies not only using the random effects model, but also indicates that moderators may be present for the relationship between turnover rates and organizational performance. A few studies in the full analysis contained extremely large samples because the authors obtained data from nationwide surveys or very large panels (Baron et al., 2001; Bingley \& Westergaard-Nielsen, 2004; Siebert \& Zubanov, 2009). In such cases, Hunter and Schmidt (2004) recommended removing extreme observations from the analysis for a robustness check to 
Table 2

Meta-Analysis of the Relationship Between Turnover Rates and Organizational Performance: Overall Analysis

\begin{tabular}{|c|c|c|c|c|c|c|c|c|c|c|}
\hline Sample characteristics & $k$ & $k_{\text {corr }}$ & $N$ & $r$ & $\rho$ & $S E_{\rho}$ & $\% \mathrm{VE}$ & $95 \% \mathrm{CI}$ & $80 \% \mathrm{CV}$ & $Q$ \\
\hline \multicolumn{11}{|l|}{ All correlations } \\
\hline All studies & 110 & 300 & 309,245 & -.10 & -.15 & .01 & 67.21 & $(-.16,-.13)$ & $(-.33, .04)$ & $4,358.28^{* * *}$ \\
\hline$N>10,000$ studies dropped & 107 & 290 & 162,275 & -.11 & -.16 & .01 & 74.84 & $(-.18,-.14)$ & $(-.37, .06)$ & $3,676.65^{\text {*** }}$ \\
\hline$\alpha=1.0$ & 110 & 300 & 309,245 & -.10 & -.10 & .01 & 55.60 & $(-.11,-.09)$ & $(-.24, .04)$ & $2,284.34^{* * *}$ \\
\hline$\alpha=.7$ & 110 & 300 & 309,245 & -.10 & -.15 & .01 & 68.73 & $(-.17,-.14)$ & $(-.34, .03)$ & $4,661.92^{* * *}$ \\
\hline \multicolumn{11}{|l|}{ One correlation per study } \\
\hline All studies & 110 & 110 & 120,066 & -.10 & -.14 & .01 & 60.27 & $(-.16,-.11)$ & $(-.29, .02)$ & $1,044.02^{* * *}$ \\
\hline$N>10,000$ studies dropped & 107 & 107 & 57,236 & -.11 & -.15 & .01 & 67.84 & $(-.17,-.12)$ & $(-.33, .04)$ & $858.30^{* *}$ \\
\hline$\alpha=1.0$ & 110 & 110 & 120,066 & -.10 & -.10 & .01 & 50.52 & $(-.12,-.08)$ & $(-.23, .03)$ & $655.26^{\text {*** }}$ \\
\hline$\alpha=.7$ & 110 & 110 & 120,066 & -.10 & -.16 & .01 & 65.95 & $(-.18,-.13)$ & $(-.33, .01)$ & $1,337.26^{* *}$ \\
\hline
\end{tabular}

Note. $\quad k=$ number of studies; $k_{\text {corr }}=$ total number of correlations; $N=$ total sample size for all studies combined; $r=$ sample size weighted averaged observed correlation; $\rho=$ averaged corrected correlation (corrected for measurement error in the predictor and criterion); $S E_{\rho}=$ standard error of $\rho$; $\% \mathrm{VE}=$ percentage of variance in $\rho$ accounted for by sampling error and measurement error in the criterion; $95 \% \mathrm{CI}=2.5 \%$ lower and $97.5 \%$ upper limits of $95 \%$ confidence interval of $\rho ; 80 \% \mathrm{CV}=$ lower and upper bounds of the $80 \%$ credibility value for $\rho ; Q=$ homogeneity statistic $Q$.

*** $p<.01$.

evaluate whether they disproportionately influenced the results. As shown in the second row of Table 2, the robustness check eliminating the three studies with very large samples revealed that the correlation magnitude increased slightly to -.16 (95\% CI $[-.18$, $-.14])$. In addition, because we used somewhat arbitrary number, .8 , to correct for unreliability, we checked the robustness of the results by assuming perfect measurement reliability (1.0) and a lower reliability level of .7. The third and fourth rows of the upper panel of Table 2 show that the turnover rates-performance correlation was -.10 (95\% CI [-.11, -.09]) when we used a reliability score of 1.0, and the correlation was -.15 (95\% CI [-.17, -.14]) when we used a reliability score of .7 .

To further examine robustness issues, we also considered whether using multiple correlations from one study (e.g., those that included multiple performance dimensions; viz., Arthur, 1994; Shaw, Gupta, \& Delery, 2005) influenced the overall results. The bottom panel of Table 2 addresses this issue: it shows the results when we averaged multiple correlations and used only one correlation from each study. Even with this change, the rho and associated statistics were substantively identical to the results using all correlations in the top panel of Table 2. An alternative approach would be to randomly sample a single correlation from those studies that reported multiple correlations rather than averaging the results. Additional checks using this approach yielded nearly identical results. Although we combined non-independent correlations (e.g., correlations based on multiple measures of the same criterion in the same sample) in the full sample results, it is still possible that use of multiple correlations from the same sample can bias the confidence and credibility intervals. Thus, we use one correlation per study in the following moderator analyses. Note that the moderator analyses results were, like the overall analyses results, substantially similar when all available correlations (i.e., 300 correlations) were used.

\section{Organization- and Context-Related Moderators}

Table 3 shows the tests of our organization-, context-, and methods-related moderators. The top panel rows show the moderating effect of the turnover rate types (voluntary, involuntary, RIF, and total turnover rates). The between-group goodness-of-fit sta- tistic $Q_{B}$ shows that the correlations between turnover rates and organizational performance were not significantly different across turnover types, $Q_{B}(3)=2.56, n s$. However, the results show that the size of the negative correlation between involuntary turnover rates and organizational performance $(\rho=-.01,95 \%$ CI $[-.18$, .16]) was smaller than the associated correlations with voluntary turnover rates and organizational performance $(\rho=-.15,95 \% \mathrm{CI}$ $[-.21,-.09])$, RIF turnover rates and organizational performance $(\rho=-.17,95 \%$ CI $[-.29,-.06])$, and total turnover rates and organizational performance $(\rho=-.14,95 \%$ CI $[-.19,-.10])$.

The second set of results in Table 3 shows the moderation results for the dimensions of organizational performance. The variance of turnover rates-performance correlations was significantly different across performance types, $Q_{B}(6)=12.75, p<.05$. Specifically, the negative turnover rates-performance correlations were large when we measured performance as customer satisfaction $(\rho=-.28,95 \% \mathrm{CI}[-.38,-.19])$ and quality $(\rho=-.26,95 \%$ CI $[-.41,-.11])$. The relationship was somewhat weaker but also significant and negative when we examined employee work attitudes $(\rho=-.19,95 \%$ CI $[-.32,-.05])$, workforce productivity ( $\rho=-.13,95 \%$ CI $[-.18,-.09])$, and financial performance $(\rho=$ $-.11,95 \%$ CI $[-.17,-.06])$. Because correlations for safety-related performance measures were fewer than four, we removed that from the list. Furthermore, we tested the moderation effects of the three dimensions of organizational performance: proximal, moderately proximal, and distal performance. The pairwise comparison results show stronger negative turnover rates-performance correlations when performance was measured as proximal performance $(\rho=-.25,95 \%$ CI $[-.33,-.17])$ than moderately proximal $(\rho=$ $-.15,95 \%$ CI $[-.19,-.10]), Q_{B}(1)=5.20, p<.05$, and distal $(\rho=$ $-.11,95 \%$ CI $[-.16,-.06]), Q_{B}(1)=7.53, p<.01$.

The third set of results in Table 3 shows the moderating effect of employment systems. The results show that the correlations between turnover rates and organizational performance were significantly different across different employment systems, $Q_{B}(3)=$ 8.92, $p<.05$. The turnover rates-organizational performance correlation was significant and negative for primary employment systems $(\rho=-.22,95 \%$ CI $[-.28,-.16])$ and executive employment systems $(\rho=-.13,95 \%$ CI $[-.22,-.03])$. The pairwise 
Table 3

Meta-Analysis of the Relationship Between Turnover Rates and Organizational Performance: Moderator Analysis

\begin{tabular}{|c|c|c|c|c|c|c|c|c|c|c|}
\hline Sample characteristics & $k$ & $N$ & $r$ & $\rho$ & $S E_{\rho}$ & $\% \mathrm{VE}$ & $95 \% \mathrm{CI}$ & $80 \% \mathrm{CV}$ & $Q_{B}$ & $Q_{W}$ \\
\hline & \multicolumn{10}{|c|}{ Organization- and context-related moderators } \\
\hline Turnover rate type & & & & & & & & & 2.56 & 125.80 \\
\hline Voluntary & 37 & 10,985 & -.11 & -.15 & .03 & 79.97 & $(-.21,-.09)$ & $(-.40, .10)$ & & 31.83 \\
\hline Involuntary & 5 & 9,017 & -.00 & -.01 & .09 & 80.91 & $(-.18, .16)$ & $(-.26, .23)$ & & 12.30 \\
\hline RIF & 11 & 4,665 & -.13 & -.17 & .06 & 78.14 & $(-.29,-.06)$ & $(-.42, .08)$ & & 20.01 \\
\hline Total & 67 & 97,435 & -.11 & -.14 & .02 & 80.87 & $(-.19,-.10)$ & $(-.39, .11)$ & & 61.67 \\
\hline Dimensions of organizational performance & & & & & & & & & $12.75^{*}$ & 170.56 \\
\hline Workforce productivity & 61 & 56,761 & -.10 & -.13 & .03 & 81.37 & $(-.18,-.09)$ & $(-.39, .12)$ & & 51.60 \\
\hline Financial performance & 53 & 76,159 & -.08 & -.11 & .03 & 80.34 & $(-.17,-.06)$ & $(-.37, .14)$ & & 48.85 \\
\hline Customer satisfaction & 17 & 14,124 & -.21 & -.28 & .05 & 76.30 & $(-.38,-.19)$ & $(-.54,-.02)$ & & 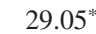 \\
\hline Employee work attitudes & 8 & 3,853 & -.15 & -.19 & .07 & 83.06 & $(-.32,-.05)$ & $(-.44, .06)$ & & 7.54 \\
\hline Quality & 8 & 3,989 & -.19 & -.26 & .07 & 69.67 & $(-.41,-.11)$ & $(-.53, .01)$ & & 9.20 \\
\hline \multirow[t]{2}{*}{ Overall performance } & 14 & 5,577 & -.16 & -.20 & .05 & 83.62 & $(-.30,-.10)$ & $(-.45, .05)$ & \multirow{5}{*}{$8.70^{*}$} & $23.79^{*}$ \\
\hline & & & & & & & & & & 159.08 \\
\hline Proximal performance & 25 & 17,977 & -.19 & -.25 & .04 & 77.28 & $(-.33,-.17)$ & $(-.50, .00)$ & & $40.00^{*}$ \\
\hline Moderately proximal performance & 72 & 61,476 & -.11 & -.15 & .02 & 79.75 & $(-.19,-.10)$ & $(-.39, .10)$ & & 67.48 \\
\hline Distal performance & 53 & 76,159 & -.08 & -.11 & .03 & 79.91 & $(-.16,-.06)$ & $(-.36, .13)$ & & 51.60 \\
\hline \multicolumn{9}{|l|}{ Employment systems } & \multirow[t]{5}{*}{$8.92^{*}$} & 121.35 \\
\hline Primary & 31 & 23,938 & -.16 & -.22 & .03 & 71.24 & $(-.28,-.16)$ & $(-.43, .00)$ & & 37.17 \\
\hline Secondary & 10 & 17,223 & -.06 & -.09 & .05 & 86.05 & $(-.18, .01)$ & $(-.28, .11)$ & & 4.16 \\
\hline Executive & 12 & 11,196 & -.09 & -.13 & .05 & 74.13 & $(-.22,-.03)$ & $(-.34, .08)$ & & 12.84 \\
\hline All & 64 & 93,501 & -.09 & -.12 & .02 & 75.99 & $(-.16,-.08)$ & $(-.33, .09)$ & & 67.18 \\
\hline \multicolumn{9}{|l|}{ Industry } & \multirow[t]{9}{*}{14.86} & 114.26 \\
\hline Manufacturing & 13 & 27,512 & -.09 & -.13 & .04 & 69.78 & $(-.22,-.04)$ & $(-.34, .09)$ & & 17.02 \\
\hline Service & 14 & 5,339 & -.11 & -.15 & .04 & 73.45 & $(-.24,-.07)$ & $(-.36, .06)$ & & 12.69 \\
\hline Banking & 6 & 523 & -.23 & -.29 & .07 & 59.02 & $(-.43,-.14)$ & $(-.52,-.05)$ & & $13.65^{*}$ \\
\hline Education & 5 & 7,372 & -.19 & -.24 & .06 & 87.20 & $(-.37,-.11)$ & $(-.43, .05)$ & & 3.11 \\
\hline Hospital & 7 & 1,591 & -.18 & -.23 & .06 & 65.39 & $(-.35,-.10)$ & $(-.45,-.01)$ & & 1.59 \\
\hline Restaurant & 8 & 4,015 & -.13 & -.19 & .06 & 69.04 & $(-.31,-.08)$ & $(-.41, .02)$ & & 6.32 \\
\hline Retail & 8 & 13,808 & -.01 & -.02 & .06 & 74.18 & $(-.14, .09)$ & $(-.23, .18)$ & & $17.55^{*}$ \\
\hline \multirow{2}{*}{\multicolumn{9}{|c|}{ Region }} & & 38.56 \\
\hline & & & & & & & & & \multirow[t]{5}{*}{$14.65^{* *}$} & 115.36 \\
\hline North America & 67 & 37,569 & -.15 & -.19 & .02 & 70.56 & $(-.23,-.15)$ & $(-.40, .02)$ & & 60.32 \\
\hline Europe & 23 & 67,621 & -.05 & -.06 & .03 & 83.12 & $(-.12,-.00)$ & $(-.26, .13)$ & & $40.28^{*}-x-2 x-1$ \\
\hline Asia & 17 & 11,762 & -.07 & -.09 & .04 & 74.21 & $(-.17,-.02)$ & $(-.30, .11)$ & & 12.31 \\
\hline \multirow[t]{2}{*}{ All } & 3 & 3,114 & -.06 & -.09 & .09 & 80.33 & $(-.26, .09)$ & $(-.29, .11)$ & & 2.45 \\
\hline & \multicolumn{10}{|c|}{ Methods-related moderators } \\
\hline \multicolumn{9}{|l|}{ Unit of analysis } & \multirow[t]{4}{*}{1.77} & 112.94 \\
\hline Organization & 67 & 90,349 & -.10 & -.13 & .02 & 79.00 & $(-.17,-.09)$ & $(-.35, .09)$ & & 52.03 \\
\hline Units in one organization & 32 & 25,234 & -.12 & -.16 & .03 & 71.91 & $(-.22,-.10)$ & $(-.39, .07)$ & & $47.75^{*}-x-2 \cos$ \\
\hline Units in multiple organizations & 11 & 4,483 & -.15 & -.20 & .05 & 76.54 & $(-.30,-.09)$ & $(-.42, .02)$ & & 13.16 \\
\hline \multicolumn{9}{|l|}{ Data structure } & $18.56^{* * *}$ & 122.28 \\
\hline Cross-sectional & 81 & 70,512 & -.10 & -.13 & .02 & 73.86 & $(-.17,-.10)$ & $(-.34, .07)$ & & 81.34 \\
\hline Lagged performance & 31 & 13,438 & -.18 & -.23 & .03 & 69.01 & $(-.29,-.18)$ & $(-.45,-.02)$ & & 31.55 \\
\hline Panel & 7 & 42,467 & .01 & .02 & .05 & 87.89 & $(-.08, .13)$ & $(-.17, .21)$ & & 9.38 \\
\hline Source of turnover rates information & & & & & & & & & 0.14 & 113.84 \\
\hline Organizational record & 52 & 101,161 & -.11 & -.15 & .02 & 78.34 & $(-.20,-.11)$ & $(-.37, .07)$ & & $75.97^{*}$ \\
\hline Key informant & 58 & 18,906 & -.11 & -.14 & .02 & 75.22 & $(-.19,-.10)$ & $(-.36, .08)$ & & 37.86 \\
\hline Role of turnover rates & & & & & & & & & 1.89 & 115.25 \\
\hline Independent variable & 49 & 83,407 & -.11 & -.14 & .02 & 77.13 & $(-.19,-.09)$ & $(-.36, .08)$ & & 57.92 \\
\hline Dependent variable & 44 & 21,253 & -.12 & -.16 & .03 & 72.27 & $(-.21,-.11)$ & $(-.38, .07)$ & & 36.95 \\
\hline Mediator & 9 & 3,597 & -.13 & -.18 & .05 & 83.91 & $(-.29,-.08)$ & $(-.39, .03)$ & & 9.83 \\
\hline Control & 8 & 9,072 & -.07 & -.09 & .06 & 85.37 & $(-.21, .02)$ & $(-.30, .12)$ & & 10.23 \\
\hline Hypothesized & & & & & & & & & 0.02 & 113.90 \\
\hline Hypothesized & 58 & 90,226 & -.11 & -.15 & .02 & 78.01 & $(-.19,-.10)$ & $(-.37, .07)$ & & 65.20 \\
\hline Not hypothesized & 52 & 29,841 & -.11 & -.14 & .02 & 75.20 & $(-.19,-.10)$ & $(-.37, .08)$ & & 48.70 \\
\hline Journal quality & & & & & & & & & 0.24 & 113.92 \\
\hline Top journal & 45 & 35,519 & -.12 & -.16 & .03 & 74.50 & $(-.21,-.10)$ & $(-.38, .07)$ & & 45.79 \\
\hline Non-top journal & 65 & 84,547 & -.11 & -.14 & .02 & 78.15 & $(-.18,-.10)$ & $(-.36, .08)$ & & 68.13 \\
\hline
\end{tabular}

Note. $\quad k=$ number of correlations from independent samples; $N=$ total sample size for all studies combined; $r=$ sample size weighted averaged observed correlation; $\rho=$ averaged corrected correlation (corrected for measurement error in the predictor and criterion); $S E_{\rho}=$ standard error of $\rho$; $\%$ VE $=$ percentage of variance in $\rho$ accounted for by sampling error and measurement error in the criterion; $95 \% \mathrm{CI}=2.5 \%$ lower and $97.5 \%$ upper limits of $95 \%$ confidence interval of $\rho ; 80 \% \mathrm{CV}=$ lower and upper bounds of the $80 \%$ credibility value for $\rho ; Q_{B}=$ homogeneity statistic $Q$ between groups; $Q_{W}=$ homogeneity statistic $Q$ within groups; RIF = reduction-in-force.

${ }^{*} p<.05 .{ }^{* *} p<.01$. 
comparison results show that the negative turnover ratesperformance correlation was marginally significantly weaker for secondary employment systems $(\rho=-.09,95 \%$ CI $[-.18, .01])$ than for primary employment systems, $Q_{B}(1)=3.66, p=.06$.

Because entity size was a continuous variable, we examined its moderating effect using weighted regression analysis (Hedges \& Olkin, 1985; Lipsey \& Wilson, 2001, p. 122; for examples also see Greenwald et al., 2009; Kirca et al., 2011). We took the natural log of the entity size variable to address distribution skewness before entering it into the regression equation. We used the available studies reporting entity size information but excluded three because they included alternative measures of entity size, such as supermarket square footage (Shaw et al., 2012), hospital bed counts (Shortell et al., 1994), and barrels produced at concrete companies (Keck, 1997). The weighted regression results using all turnover rates samples (regardless of turnover types) are shown in the top part of Table 4. As the table shows, entity size was significantly and positively related to the turnover ratesorganizational performance correlation $(b=.04, \beta=.41, p<$ $.01)$. Thus, entity size significantly moderated the turnover ratesperformance correlation so that the turnover rates and organizational performance correlation was negative but weaker in samples with larger entities.

Also in Table 3 are the moderation results for industries. In contrast to our expectation, the moderating effect of industry was not statistically significant, $Q_{B}(10)=14.86, n s$. The turnover rates-organizational performance relationship was significantly different than zero in banking $(\rho=-.29,95 \%$ CI $[-.43,-.14])$, education $(\rho=-.24,95 \%$ CI $[-.37,-.11])$, hospitals $(\rho=-.23$, $95 \%$ CI $[-.35,-.10])$, restaurants $(\rho=-.19,95 \%$ CI $[-.31,-.08])$, services $(\rho=-.15,95 \%$ CI $[-.24,-.07])$, and manufacturing $(\rho=$ $-.13,95 \%$ CI $[-.22,-.04])$ samples. The relationship was not significantly different than zero in retail samples $(\rho=-.02,95 \%$ CI $[-.14, .09])$. We removed computer technology, petroleum, and government industries moderation effects from the table because they had fewer than four correlations.

Table 4

Meta-Analytic Regression Analysis: Entity Size Moderation

\begin{tabular}{lrrrr}
\hline & \multicolumn{5}{c}{$\begin{array}{c}\text { Turnover-performance } \\
\text { correlations }(\rho)\end{array}$} \\
\cline { 2 - 6 } \multicolumn{1}{c}{ Moderators } & $b$ & $\beta$ & $(p)$ & $z$ \\
\hline Full sample $(k=37)$ & & & & \\
$\quad$ Constant & -.35 & .00 & $(.00)$ & -4.92 \\
Entity size & .04 & .41 & $(.00)$ & 2.95 \\
$R^{2}$ & .17 & & $(.00)$ & \\
v [se(v)] & .01 & {$[.00]$} & & \\
Voluntary turnover sample $(k=15)$ & & & & \\
Constant & -.46 & .00 & $(.00)$ & -3.60 \\
Entity size & .06 & .45 & $(.04)$ & 2.10 \\
$R^{2}$ & .21 & & $(.04)$ & \\
v [se(v)] & .01 & {$[.01]$} & & \\
\hline
\end{tabular}

Note. Analyses were conducted using mixed-effects models (fixed predictor slopes, random intercepts) with maximum likelihood estimation. $k=$ number of correlations from independent samples in each analysis; $b=$ unstandardized regression coefficient; $\beta=$ standardized regression coefficient; $z=$ critical ratio test for the regression coefficient; $p=$ two-tailed probability of $z ; \mathrm{v}=$ maximum likelihood random effects variance component; $\mathrm{se}(\mathrm{v})=$ standard error of estimated variance component.
The fifth set of results in Table 3 shows that region had a significant moderating effect, $Q_{B}(3)=14.65, p<.01$. As expected, the turnover rates and performance correlation was more strongly negative in North America ( $\rho=-.19$, 95\% CI [-.23, $-.15]$ ) than in regions that have relatively rigid markets (Asia, $\rho=$ $-.09,95 \%$ CI [-.17, -.02]; Europe, $\rho=-.06,95 \%$ CI [-.12, - .00]).

\section{Methods-Related Moderators}

The bottom half of Table 3 shows the results for methodsrelated moderators. The moderation results for unit of analysis showed that correlation sizes were not significantly different across unit of analysis, $Q_{B}(2)=1.77$, ns. The turnover ratesorganizational performance correlations were significantly different than zero in unit-level samples in single organizations $(\rho=$ $-.16,95 \%$ CI $[-.22,-.10])$, for samples with units in multiple organizations $(\rho=-.20,95 \%$ CI $[-.30,-.09])$, and for organization-level samples $(\rho=-.13,95 \%$ CI $[-.17,-.09])$.

The next panel shows that data structure was a significant moderator, $Q_{B}(2)=18.56, p<.01$; turnover rates-organizational performance correlation was significant when cross-sectional $(\rho=$ $-.13,95 \%$ CI $[-.17,-.10])$ and lagged $(\rho=-.23,95 \%$ CI $[-.29$, $-.18])$ designs were used, but not when panel designs $(\rho=.02$, $95 \%$ CI $[-.08, .13])$ were used. As noted, the correlations from studies coded as "panel" were average correlations across organization-years. Thus, this represents a weak test of the moderating effect of a panel design.

The turnover rates-organizational performance relationship was not significantly moderated by the source of turnover rates, $Q_{B}(1)=0.14, n s$, the role of the turnover rates variable, $Q_{B}(4)=1.89$, $n s$, whether researchers predicted a relationship between turnover rates and organizational performance, $Q_{B}(1)=0.02, n s$, or journal quality (top journals vs. non-top journals), $Q_{B}(1)=0.24, n s$.

\section{Moderator Analyses for Voluntary Turnover Rates}

Table 5 displays the results when only voluntary turnover rates samples were used for the meta-analysis. We analyzed voluntary turnover rates separately because voluntary turnover rates are the focal variable in the many macro-level turnover studies. We summarize the results below briefly, with a focus on the differences between the voluntary turnover rates results and those from the full sample. Although many results in Table 5 are similar to the total turnover rates results in Table 3, several notable differences appear.

In the voluntary turnover rates tests, the dimensions of organizational performance were significant moderators, $Q_{B}(6)=15.89$, $p<.05$, but the patterns were somewhat different than with the full sample. The correlation between turnover rates and workforce productivity was similar for the full sample $(\rho=-.13,95 \% \mathrm{CI}$ $[-.18,-.09])$ and the voluntary turnover rates-only sample $(\rho=$ $-.15,95 \%$ CI $[-.21,-.08])$, but the correlation was not significant for voluntary turnover rates and financial performance $(\rho=.01$, $95 \%$ CI $[-.08, .11]$ ), whereas the corresponding financial performance results for the full sample was significant $(\rho=-.11,95 \% \mathrm{CI}$ $[-.17,-.06])$. The moderation effects of the three dimensions of organizational performance-proximal, moderately proximal, and distal performance-were similar to the results from the full sample. The moderating role of employment systems was not significant in the voluntary turnover rates sample, $Q_{B}(2)=3.80, n s$. 
Table 5

Meta-Analysis of the Relationship Between Voluntary Turnover Rates and Organizational Performance: Moderator Analysis

\begin{tabular}{|c|c|c|c|c|c|c|c|c|c|c|}
\hline Sample characteristics & $k$ & $N$ & $r$ & $\rho$ & $S E_{\rho}$ & $\% \mathrm{VE}$ & $95 \% \mathrm{CI}$ & $80 \% \mathrm{CV}$ & $Q_{B}$ & $Q_{W}$ \\
\hline & \multicolumn{10}{|c|}{ Organization- and context-related moderators } \\
\hline Dimensions of organizational performance & & & & & & & & & $15.89^{*}$ & 48.59 \\
\hline Workforce productivity & 22 & 6,708 & -.11 & -.15 & .03 & 73.99 & $(-.21,-.08)$ & $(-.34, .05)$ & & 16.45 \\
\hline \multirow[t]{2}{*}{ Financial performance } & 10 & 5,909 & .01 & .01 & .05 & 75.84 & $(-.08, .11)$ & $(-.18, .21)$ & & 9.92 \\
\hline & 7 & 807 & -.20 & -.25 & .06 & 64.37 & $(-.37,-.13)$ & $(-.46,-.04)$ & $13.10^{* *}$ & $\begin{array}{l}47.55 \\
12.97^{*}\end{array}$ \\
\hline Moderately proximal performance & 27 & 7828 & -.12 & -.15 & .03 & 73.62 & $(-.21,-.10)$ & $(-.35, .04)$ & & $\begin{array}{l}12.91 \\
24.72\end{array}$ \\
\hline Distal performance & 10 & 5909 & .01 & .01 & .05 & 76.17 & $(-.08, .11)$ & $(-.18, .21)$ & & 9.86 \\
\hline Employment systems & & & & & & & & & 3.80 & 40.11 \\
\hline Primary & 9 & 1,289 & -.17 & -.23 & .06 & 64.12 & $(-.34,-.12)$ & $(-.45,-.01)$ & & 8.60 \\
\hline Secondary & 4 & 919 & -.15 & -.19 & .08 & 76.99 & $(-.35,-.04)$ & $(-.39, .01)$ & & 1.51 \\
\hline All & 24 & 8,777 & -.08 & -.11 & .03 & 74.94 & $(-.17,-.05)$ & $(-.31, .10)$ & & 30.00 \\
\hline Industry & & & & & & & & & $14.73^{*}$ & $41.71^{*}$ \\
\hline Manufacturing & 4 & 373 & -.10 & -.14 & .08 & 52.41 & $(-.29, .01)$ & $(-.34, .06)$ & & $10.84^{*}$ \\
\hline Service & 9 & 3,598 & -.13 & -.18 & .05 & 63.56 & $(-.27,-.08)$ & $(-.36, .00)$ & & 7.13 \\
\hline Cross industry & 17 & 5,985 & -.11 & -.14 & .03 & 74.75 & $(-.20,-.08)$ & $(-.31, .03)$ & & 15.77 \\
\hline Region & & & & & & & & & 4.00 & 41.90 \\
\hline North America & 20 & 3,466 & -.15 & -.19 & .03 & 67.38 & $(-.26,-.12)$ & $(-.40, .02)$ & & 12.88 \\
\hline Europe & 8 & 3,357 & -.07 & -.10 & .04 & 74.87 & $(-.21, .00)$ & $(-.30, .09)$ & & $25.13^{\text {*** }}$ \\
\hline \multirow[t]{2}{*}{ Asia } & 8 & 1,803 & -.08 & -.11 & .05 & 75.42 & $(-.21, .00)$ & $(-.30, .09)$ & & 3.88 \\
\hline & \multicolumn{10}{|c|}{ Methods-related moderators } \\
\hline Unit of analysis & & & & & & & & & 2.21 & 38.39 \\
\hline Organization & 20 & 4,496 & -.10 & -.12 & .04 & 77.50 & $(-.19,-.05)$ & $(-.33, .09)$ & & 11.87 \\
\hline Units in one organization & 11 & 3,075 & -.15 & -.21 & .05 & 65.43 & $(-.32,-.11)$ & $(-.45, .02)$ & & $24.32^{* * *}$ \\
\hline Units in multiple organizations & 6 & 3,414 & -.09 & -.12 & .07 & 80.95 & $(-.25, .01)$ & $(-.32, .09)$ & & 2.20 \\
\hline Data structure & & & & & & & & & $3.94^{*}$ & 37.72 \\
\hline Cross-sectional & 25 & 8,761 & -.10 & -.13 & .03 & 69.61 & $(-.18,-.07)$ & $(-.31, .05)$ & & 23.72 \\
\hline Lagged performance & 8 & 1,332 & -.18 & -.24 & .05 & 62.42 & $(-.35,-.14)$ & $(-.43,-.06)$ & & 14.00 \\
\hline Source of turnover rates information & & & & & & & & & 0.03 & 40.53 \\
\hline Organizational record & 7 & 871 & -.09 & -.13 & .07 & 48.64 & $(-.27, .00)$ & $(-.28, .09)$ & & $18.12^{* *}$ \\
\hline Key informant & 30 & 10,114 & -.11 & -.15 & .03 & 64.34 & $(-.21,-.09)$ & $(-.27, .05)$ & & 22.41 \\
\hline Role of turnover rates & & & & & & & & & 0.45 & 40.22 \\
\hline Independent variable & 13 & 4,106 & -.11 & -.16 & .05 & 72.79 & $(-.25,-.06)$ & $(-.37, .06)$ & & $25.56^{*}$ \\
\hline Dependent variable & 19 & 5,167 & -.1 & -.15 & .04 & 72.51 & $(-.23,-.08)$ & $(-.37, .07)$ & & 13.46 \\
\hline Mediator & 5 & 1,712 & -.08 & -.10 & .07 & 87.40 & $(-.24, .03)$ & $(-.30, .10)$ & & 1.20 \\
\hline Hypothesized & & & & & & & & & 0.00 & 40.46 \\
\hline Hypothesized & 17 & 5,402 & -.10 & -.15 & .04 & 76.12 & $(-.22,-.07)$ & $(-.36, .07)$ & & $26.65^{*}$ \\
\hline Not hypothesized & 20 & 5,583 & -.11 & -.15 & .04 & 73.47 & $(-.22,-.07)$ & $(-.36, .07)$ & & 13.81 \\
\hline Journal quality & & & & & & & & & 0.10 & 40.42 \\
\hline Top journal & 11 & 3,988 & -.12 & -.16 & .05 & 68.61 & $(-.26,-.06)$ & $(-.39, .07)$ & & 30.47 \\
\hline Non-top journal & 26 & 6,997 & -.11 & -.14 & .03 & 77.01 & $(-.20,-.08)$ & $(-.35, .07)$ & & 9.95 \\
\hline
\end{tabular}

Note. $\quad k=$ number of correlations from independent samples; $N=$ total sample size for all studies combined; $r=$ sample size weighted averaged observed correlation; $\rho=$ averaged corrected correlation (corrected for measurement error in the predictor and criterion); $S E_{\rho}=$ standard error of $\rho$; $\%$ VE $=$ percentage of variance in $\rho$ accounted for by sampling error and measurement error in the criterion; $95 \% \mathrm{CI}=2.5 \%$ lower and $97.5 \%$ upper limits of $95 \%$ confidence interval of $\rho ; 80 \% \mathrm{CV}=$ lower and upper bounds of the $80 \%$ credibility value for $\rho ; Q_{B}=$ homogeneity statistic $Q$ between groups; $Q_{W}=$ homogeneity statistic $Q$ within groups.

${ }^{*} p<.05 .{ }^{* *} p<.01$.

The moderating effect of entity size using a weighted regression is shown in the lower part of Table 4 . The pattern of findings was similar to the full sample results $(b=.06, \beta=.45, p<.05)$.

Another notable difference in the voluntary turnover rates moderator results involved employment systems. The primary employment systems moderation effect was similar for the full sample $(\rho=-.22,95 \%$ CI $[-.28,-.16])$ and the voluntary turnover ratesonly sample $(\rho=-.23,95 \%$ CI $[-.34,-.12])$. However, the secondary employment system moderation effect was significant and negative in voluntary turnover rates-only sample $(\rho=-.19,95 \%$ CI $[-.35,-.04])$, but the corresponding moderation effect for the full sample was not significant $(\rho=-.09,95 \%$ CI $[-.18, .01])$. Note, however, that many of the differences between results from the full sample (see Table 3) and the voluntary turnover rates sample (see Table 5) could be due to smaller number of correlations for the latter sample.

\section{Exploratory Sample-Level Regression Results: Average Turnover Rates Level and the Turnover Rates-Organizational Performance Correlation}

For our final analysis, we examined whether the relationship between turnover rates and organizational performance varied in magnitude across samples based on the average levels of turnover reported (see Table 6). These do not directly test the alternative theories outlined in the introduction, because the alternative theo- 
Table 6

Meta-Analytic Regression Analysis: Average Sample-Level Turnover Rates and the Turnover Rates-Organizational Performance Correlation

\begin{tabular}{|c|c|c|c|c|c|c|c|c|}
\hline \multirow[b]{3}{*}{ Moderators } & \multicolumn{8}{|c|}{ Turnover rates-organizational performance correlation $(\rho)$} \\
\hline & \multicolumn{4}{|c|}{ Step 1} & \multicolumn{4}{|c|}{ Step 2} \\
\hline & $b$ & $\beta$ & $(p)$ & $z$ & $b$ & $\beta$ & $(p)$ & $z$ \\
\hline \multicolumn{9}{|l|}{ Total turnover rates level moderation $(k=103)$} \\
\hline Constant & -.12 & .00 & $(.00)$ & -5.47 & -.13 & .00 & $(.00)$ & -4.71 \\
\hline Average turnover rates & -.12 & -.22 & $(.02)$ & -2.28 & -.02 & -.05 & $(.85)$ & -0.18 \\
\hline Average Total Turnover Rates $\times$ Average Total Turnover Rates & & & & & -.06 & -.19 & (.44) & -0.76 \\
\hline 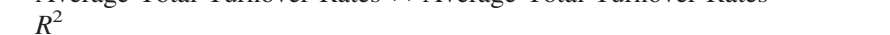 & .05 & & $(.02)$ & & .05 & & (.05) & \\
\hline $\mathrm{v}[\mathrm{se}(\mathrm{v})]$ & .02 & {$[.00]$} & & & .02 & {$[.00]$} & & \\
\hline \multicolumn{9}{|l|}{ Voluntary turnover rates level moderation $(k=31)$} \\
\hline Constant & -.05 & .00 & (.19) & -1.31 & -.05 & .00 & $(.45)$ & -0.75 \\
\hline Average voluntary turnover rates & -.60 & -.46 & $(.00)$ & -3.02 & -.58 & -.44 & $(.45)$ & -0.75 \\
\hline Average Voluntary Turnover Rates $\times$ Average Voluntary Turnover Rates & & & & & -.04 & -.01 & (.98) & -0.02 \\
\hline 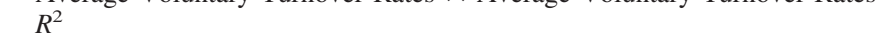 & .21 & & $(.00)$ & & .21 & & (.01) & \\
\hline $\mathrm{v}[\mathrm{se}(\mathrm{v})]$ & .01 & {$[.00]$} & & & .01 & {$[.00]$} & & \\
\hline
\end{tabular}

Note. Analyses were conducted using mixed-effects models (fixed predictor slopes, random intercepts) with maximum likelihood estimation. $k=$ number of correlations from independent samples in each analysis; $b=$ unstandardized regression coefficient; $\beta=$ standardized regression coefficient; $z=$ critical ratio test for the regression coefficient; $p=$ two-tailed probability of $z ; \mathrm{v}=$ maximum likelihood random effects variance component; se(v) $=$ standard error of estimated variance component.

ries reside at the organizational level (e.g., they were developed to test the relationship in between-organizations designs), whereas the sample level is the unit of analysis in these regressions. They do, however, provide some evidence illuminating the alternative models.

The top part of Table 6 shows the weighted regression results when sample-level average total turnover rates are the independent variable and the turnover rates-organizational performance correlations are the dependent variable. In Step 1, average total turnover rates were significantly and negatively related to the correlation between total turnover rates and organizational performance $(b=$ $-.12, \beta=-.22, p=.02$ ). In Step 2, we entered the squared average turnover rate variable. The squared turnover rates term was not significant $(b=-.06, \beta=-.19, n s)$. Thus, in terms of the sample-level conclusion with turnover rates of all types, the turnover rates and organizational performance relationship became more negative as average turnover rates increased.

In the bottom part of Table 6, we report the weighted regressions after restricting the sample to only those studies that examined voluntary turnover rates. In Step 1, the linear average sample-level voluntary turnover term was significantly and negatively related to the voluntary turnover rates-organizational performance correlations $(b=-.60, \beta=-.46, p=.00)$. In Step 2 , the squared average voluntary turnover rates term was not statistically significant $(b=$ $-.04, \beta=-.01, n s)$. Note, however, that when we restricted our sample to voluntary turnover only, average voluntary turnover rates ranged from near zero to .5 , with no observation greater than .5. Thus, our results can be interpreted, at best, to show that the voluntary turnover rates and organizational performance correlation becomes more negative as average voluntary turnover rates increase from zero to .5 .

These two sets of results generally suggest that the relationship between turnover rates and organizational performance is nonlinear; if the relationship at the organizational level were linear, we would expect a flat (nonsignificant) slope in the relationship be- tween average turnover rates and the turnover rates-performance correlation. That is, the relationship should be invariant across average turnover rate levels. In terms of the voluntary turnover rates results, the results also contrast with the inverted-U formulation (Model 3), because the predicted correlations became more negative as voluntary turnover rates increased from zero to .5; in no case did we observe a predicted positive correlation. We cannot make strong conclusions about the attenuated negative view (Model 2), however, because of range restriction. We discuss the implication of these results further in the discussion section.

\section{Discussion}

Most organizations regard employee turnover to be a critical concern in formulating strategies for better company performance and in countering the costs of degraded safety, productivity, customer satisfaction, and financial performance. Unsurprisingly, researchers have conducted hundreds of studies to discern why individuals quit their jobs and to design ways to control turnover (e.g., Holtom et al., 2008). Researchers have also studied how turnover rates relate to outcome at higher levels of unit and organizational analyses. We contend that we must now summarize understandings and set literature-level benchmarks for the relationship between turnover rates and organizational performance. In this study, we contribute to the literature by (a) meta-analyzing the relationship between turnover rates and organizational performance, (b) outlining and testing theoretically relevant moderators of the relationship, and (c) testing other moderating features related to contexts and methods for examining the relationship. We believe that researchers and practitioners can benefit substantially by having a reference point that characterizes the overall turnover rates-performance relationship - a point of departure for future endeavors to investigate and compare the relationship in specific contexts. In this discussion, we review our meta-analytic results and discuss future directions for macro-level turnover research. 


\section{The Relationship Between Turnover Rates and Organizational Performance}

Perhaps our most important contribution is validating the proposition that increased turnover rates damage organizational performance. After correcting for sampling and measurement artifacts across 300 turnover rate-organizational performance correlations and a sample of more than 300,000 organizations and units, the estimated meta-analytic correlation was -.15. Following Crook, Todd, Combs, Woehr, and Ketchen (2011), we interpreted this association as suggesting that a one standard deviation increase in turnover rates was associated with a -.15 standard deviation reduction in organizational performance. Per their work, we applied the overall meta-analytic result to a single sample in our analysisGuthrie, Datta, and Wadhwa's (2010) large cross-industry and nationally representative sample of U.S. organizations that showed a mean and standard deviation of 0.22 and 0.58 for workforce productivity (firm sales growth) and 3.95 and 6.97 for financial performance (firm profitability). Based on our meta-analytic findings, we would expect their sample to show that a one standard deviation increase in turnover rates from $12 \%$ to $22 \%$ decreases workforce productivity from .22 to .13 , a $40 \%$ reduction. In addition, we would expect a one standard deviation increase in turnover rates to lower financial performance from 3.95 to 2.90, a $26 \%$ reduction. Thus, a key finding from our quantitative review is that, despite some variation across moderators in our study, organizations should attempt to control turnover rates. Failing to do so may substantially reduce performance.

Detractors might point to the modest magnitude $(\rho=-.15)$ of the association and highlight that turnover rates explain only a small amount of variance in organizational performance. From a qualitative standpoint, however, Prentice and Miller (1992) argued that small effects can be considered impressive when the outcome variable has many legitimate predictors and when the outcome is "difficult-to-influence" (p. 162). In the case of organizational performance, the literature offers dozens of established correlates (e.g., location, strategy, technology, organizational processes, physical resources, and unique products and services). Therefore we can reasonably expect that single predictors provide modest explanations compared with explanations from other phenomena with fewer antecedents. Our results are consistent with other meta-analytic reviews using organizational performance as a dependent variable that report similar or often smaller effect sizes (e.g., from .02 to .21; Crook et al., 2011; Dalton et al., 1998, 1999; Geyskens, Steenkamp, \& Kumar, 2006; Heugens \& Lander, 2009; Kirca et al., 2011). Moreover, many organizations compete where fixed expenses dominate cost structures. Consequently, they attempt to leverage higher performance by manipulating a few important variables, including the quality of their human resources. In such cases, minor declines in workforce productivity through higher turnover rates may make the difference between profit and loss and, potentially, success or failure.

\section{Organization- and Context-Related Moderators}

Our meta-analysis results show that involuntary turnover rates and organizational performance correlations are quite different in size from voluntary/RIF turnover rates and organizational performance correlations. These findings validate researchers' argu- ments that careful conceptualization and operationalization of turnover rates are important because turnover types have different etiologies and consequences (Hausknecht \& Trevor, 2011; Holtom et al., 2008; Shaw, 2011). Of note, the relationship between involuntary turnover rates and organizational performance is not statistically significantly different from zero, which refutes recent theorizing that both voluntary and involuntary turnover are harmful because involuntary turnover signals problems in workforce quality (Batt \& Colvin, 2011; Hausknecht \& Trevor, 2011). Instead, this result seemingly shows that involuntary turnover is less harmful because it occurs under organizational control and may serve functional purposes such as eliminating poor performers (Abelson \& Baysinger, 1984; Holtom et al., 2008). However, such a view is also not fully supported because the involuntary turnover rates and organizational performance relationship was not positive. RIF turnover rates are strongly and negatively related with performance, which supports the proposition that RIF turnover may be dysfunctional because it increases employment instability, decreases social capital, encourages behavioral rigidity (e.g., Cameron et al., 1987), and negatively affects survivor's attitudes and behaviors.

Although these results answer some questions posed in the literature, several important unknowns remain. First, the metaanalysis fails to fully address reverse causality, and thus readers should approach our results with the same caution they use in interpreting qualitative review papers about turnover rates and organizational performance relationships (Datta et al., 2010; Hausknecht \& Trevor, 2011; Shaw, 2011). In two recent qualitative reviews, Hausknecht and Trevor (2011) and Shaw (2011) concluded that the causal relationship between total/voluntary turnover rates and organizational performance is more likely than the reverse, partly because empirical studies that have examined reverse causality empirically find much stronger results for our presumed causal sequence (e.g., Glebbeek \& Bax, 2004; Ton \& Huckman, 2008; Van Iddekinge et al., 2009). Supporting this, we show that lagged performance samples have a stronger negative association between turnover rates and organizational performance than do cross-sectional samples.

The relatively less well-established nature and causality of the relationship between RIF/involuntary turnover and organizational performance deserve more future attention. In their qualitative review of the RIF turnover literature, Datta et al. (2010) noted that "an important limitation of extant research is the overreliance on static, cross-sectional designs" (p. 339). Thus, our results for these turnover types should be interpreted with caution in light of the potential for reverse causality and confounding factors. We believe that future studies can significantly extend the turnover literature by revealing the mechanisms (or mediators) of the RIF turnover and organizational performance relationship. Another way to extend the RIF turnover literature would be to explore contextual and moderating effects on the RIF turnover and performance relationship (Datta et al., 2010). Furthermore, although RIF turnover studies are increasing, many have used RIF announcements rather than RIF turnover rates in deriving their predictions and tests (e.g., Ahmadjian \& Robinson, 2001; Cascio et al., 1997; Chalos \& Chen, 2002; Flanagan \& O'Shaughnessy, 2005; Hallock, 1998; Love \& Nohria, 2005; Perry \& Shivdasani, 2005; Wayhan \& Werner, 2000; Worrell, Davidson, \& Sharma, 1991). Examining the effects of RIF turnover rates on organizational performance 
can significantly extend our understanding because it informs both researchers and practitioners about appropriate degrees or levels of RIF turnover. For example, Lee (1997) suggested a curvilinear relationship between RIF turnover rates and organizational financial performance; negative RIF turnover effects strengthen as RIF turnover rates increase. We found no follow-up studies that examined potential curvilinearity between RIF turnover rates and organizational performance. Future studies could take a major step forward by incorporating process issues such as announcements, implementation factors, and RIF turnover levels or rates.

Similarly, we believe our results present a good point of departure for future studies to theorize and empirically examine involuntary turnover effects, perhaps the least-studied consequences in the turnover literature. We located only seven studies of involuntary turnover issues: Two investigated antecedents of involuntary turnover, not consequences (Guthrie et al., 2010; Shaw et al., 1998), and only five examined consequences (Batt \& Colvin, 2011; Chi \& Wang, 2009; McElroy et al., 2001; Simon, De Sivatte, \& Olmos, 2012; Subramony \& Holtom, 2011a). Thus, more evidence is needed. In addition, research into potential contextual factors that make the relationship more or less negative may extend our understanding of involuntary turnover effects. We can reasonably expect that the conditions that cause companies to make and implement involuntary turnover decisions would significantly moderate the involuntary turnover effects on organizational performance. Moreover, future studies must address possible confounding factors in the involuntary turnover and performance relationship; for example, poor selection might be responsible for both high involuntary turnover rates and poor organizational performance. Furthermore, future studies should clarify operationalization and measurements. Involuntary turnover may be too crude a classification; diverse forms of leaving such as dismissals, disabilities, and retirements might exert different effects. ${ }^{2}$ It is also possible that organizations report involuntary turnover information inaccurately for legal reasons. Thus, we encourage future researchers to theorize and rigorously examine the involuntary turnover and organizational performance relationship.

Recently, some researchers proposed an alternative conceptualization of turnover rather than voluntary, involuntary, and RIF turnover. Hausknecht and Holwerda (2012) considered timing aspects of turnover, and suggest five alternative conceptualizations of turnover rates: leaver proficiencies, time dispersion, positional distribution, remaining member proficiencies, and newcomer proficiencies. In addition, Nyberg and Ployhart (2012) defined unitlevel turnover as emerging from knowledge, skills, abilities, and other characteristics (KSAOs), and suggested that turnover rates effects should be understood by considering the mix of the quantity and quality of KSAOs depletion. As such, our understanding of turnover rates effects will be extended further by considering alternative conceptualizations of turnover types.

We expected our meta-analysis to show that the turnover ratesorganizational performance relationship would be stronger when performance was measured as proximal performance dimensions (e.g., customer satisfaction, employee work attitudes) rather than as moderately proximal (e.g., safety, quality, workforce productivity) or distal (e.g., financial performance). Consistent with our expectation, the results showed the strongest negative relationship for proximal performance and the weakest for distal performance. This result is consistent with Kacmar et al.'s (2006) and Shaw's
(2011) propositions that turnover impacts financial performance through workforce performance. In addition, this implies that turnover researchers should cautiously use financial performance as an organizational outcome measure because other confounding factors weaken turnover's direct effects.

The results also show that employment systems significantly moderate the turnover rates-performance relationship: the turnover rates and organizational performance relationship is more negative under primary than secondary employment systems. This finding confirms previous propositions that the emphasis on human resource management systems influences the relationship (e.g., Arthur, 1994; Guthrie, 2001; Shaw, Gupta, \& Delery, 2005). Because it takes employees significant time to reach adequate performance levels under primary systems, human and social capital losses through turnover are greater than under secondary employment systems. Extending the HRM-moderated approach, future researchers may benefit by considering various types of employee-organization relationships (Hom, Tsui, Wu, \& Lee, 2009; Shaw et al., 2009; Tsui, Pearce, Porter, \& Tripoli, 1997) when they examine turnover rates-performance relationships. For example, the direction and magnitude of the relationship may be different when organizations emphasize different levels of offered inducements (high training investments) and expected contributions (e.g., use of pay-for-performance).

Also, our results show that entity size plays a role in determining the magnitude of the turnover rates-performance correlation. This is somewhat consistent with the argument that larger entities can buffer turnover's negative effects (Green et al., 1996; Kozlowski $\&$ Bell, 2003) and better withstand the same proportional information losses (Carley, 1992). The literature provides few tests of entity size moderation, however, so we need more data before dismissing the view that turnover is less costly in smaller entities (e.g., Hausknecht et al., 2009).

Moreover, our meta-analysis results imply that the disruptive impacts of turnover, especially voluntary turnover, on organizational performance differ across industries. In general, the results show a relatively stronger negative relationship between voluntary turnover rates and organizational performance in industries with higher human capital emphasis (e.g., service industries) compared with industries with lower human capital emphasis (e.g., manufacturing). This is consistent with the contingency framework in strategic human resource management literature; an organization's industrial context alters the relative effectiveness of employment relationship policies such as downsizing (e.g., Guthrie \& Datta, 2008). From a practical standpoint, the meta-analysis results imply that practitioners in service industries may need to pay more attention to turnover rates management or hiring and staffing management than those in manufacturing/production-related industries.

Last, our results suggest regional differences in the turnover rates-organizational performance relationship; the North American samples showed a more strongly negative relationship than did the European samples. European labor markets are known for high rigidity, controlling legislation, generous unemployment benefits, and strong unionization (Nickell, 1997). Thus, the negative impacts of turnover on organizational performance may be weaker in

${ }^{2}$ We thank an anonymous reviewer for this suggestion. 
European organizations than in North American organizations because their turnover occurs for more legitimate reasons or is more predictable. Cultural differences across regions, such as collectivism versus individualism, provide another potential explanation (e.g., Hofstede, 1980). Turnover may be more disruptive for organizational performance in individualistic cultures than in collectivistic cultures because work processes are more easily disrupted in individualistic culture where each individual is encouraged to take their own unique roles. Also, organizations in individualistic cultures may have more difficulty finding internal replacements than those in collective cultures because existing employees will feel less peer pressure to complete the tasks of the departing individual. Most research on the turnover ratesperformance relationship has been conducted in individualistic countries; we lack rigorous empirical evidence from collectivistic countries. Future research capturing the moderating role of cultural variances (e.g., multinational company samples) may extend our understanding about the impacts of turnover rates.

\section{Sample-Level Regressions}

In exploratory weighted regressions, we show that turnover rates-organizational performance correlations are significantly different across samples with differing average turnover rates levels. Specifically, when we used all available correlations (regardless of turnover type), the turnover rates-organizational performance correlation became more strongly negative as the average turnover rates increased. The results were similar when we analyzed samples using only voluntary turnover rates; the nature of the relationship between sample-level average voluntary turnover rates levels and the corrected correlation was linear and negative, despite the restricted range for the average voluntary turnover rates variable.

These sample-level tests provide some information regarding the veracity of alternative views that, although not relevant as direct tests of the alternative models, can provide useful information regarding the nature of the relationship. First, these results show that average turnover rates are significantly related to the magnitude of the correlation, a finding that contradicts the linear negative view (Model 1), which presumes an invariant relationship across average turnover rates. Second, the predicted correlation between turnover rates and organizational performance was never positive and failed to support Model 3, which assumes a positive relationship between turnover rates and organizational performance as turnover rates increase from low to moderate levels. Indeed, in toto, we find no turnover benefits; the average turnover rates-performance correlation was always negative across all tests, types of turnover, and moderators. Thus our sample-level regressions contradict Model 1 (because the correlation between turnover rates and organizational performance varies across average turnover rates) and Model 3 (because turnover rates never show positive effects on organizational performance). These results provide evidence of more potent effects of voluntary turnover rates on performance at low to moderate levels, but range restrictions in average voluntary turnover rates prohibit us from drawing conclusions about attenuation effects at high levels.

\section{Conclusion}

Our meta-analysis shows that turnover rates and organizational performance are significantly and negatively related. We encourage future researchers examining the turnover rates-organizational performance relationship to (a) distinguish types of turnover (e.g., voluntary vs. involuntary) when they measure turnover rates (Shaw, 2011; Shaw et al., 1998); (b) examine possible curvilinearity in the relationship - for example, by including a squared turnover term in regression-based analyses; and (c) consider organization- and contextrelated factors. From a practitioner's viewpoint, the most straightforward implication is that turnover rates are negatively associated with organizational performance; our post hoc calculations on a single sample imply substantial negative effects on workforce and financial performance. Despite diverse views on the role of turnover (e.g., benefits vs. costs), we show that turnover rates of any type can damage organizational performance under any contextual conditions. Hence, organizations must recognize that when turnover rates rise, their workforce and financial performance are at risk. They should search for strategies to mitigate and eliminate turnover, recognizing that lower turnover is always better.

\section{References}

References marked with an asterisk indicate studies included in the meta-analysis.

Abelson, M. A., \& Baysinger, B. D. (1984). Optimal and dysfunctional turnover: Toward an organizational level model. The Academy of Management Review, 9, 331-341.

Aguinis, H., Dalton, D. R., Bosco, F. A., Pierce, C. A., \& Dalton, C. M. (2011). Meta-analytic choices and judgment calls: Implications for theory building and testing, obtained effect sizes, and scholarly impact. Journal of Management, 37, 5-38. doi:10.1177/0149206310377113

Ahmad, S., \& Schroeder, R. G. (2003). The impact of human resource management practices on operational performance: Recognizing country and industry differences. Journal of Operations Management, 21, 1943. doi:10.1016/S0272-6963(02)00056-6

Ahmadjian, C. L., \& Robinson, P. (2001). Safety in numbers: Downsizing and the deinstitutionalization of permanent employment in Japan. Administrative Science Quarterly, 46, 622-654. doi:10.2307/3094826

Alexander, J. A., Bloom, J. R., \& Nuchols, B. A. (1994). Nursing turnover and hospital efficiency: An organization-level analysis. Industrial Relations, 33, 505-520. doi:10.1111/j.1468-232X.1994.tb00355.x

*Allen, M. R., Ericksen, J., \& Collins, C. (2010). The role of intrinsic human resource management in the performance of small firms. Paper presented at the annual meeting of the Academy of Management, Montreal, Quebec, Canada.

*Angle, H. L., \& Perry, J. L. (1981). An empirical assessment of organizational commitment and organizational effectiveness. Administrative Science Quarterly, 26, 1-14. doi:10.2307/2392596

*Armstrong, C., Flood, P. C., Guthrie, J. P., Liu, W., Maccurtain, S., \& Mkamwa, T. (2010). The impact of diversity and equality management on firm performance: Beyond high performance work systems. Human Resource Management, 49, 977-998. doi:10.1002/hrm.20391

Arthur, J. B. (1992). The link between business strategy and industrial relations systems in American steel minimills. Industrial and Labor Relations Review, 45, 488-506. doi:10.2307/2524274

*Arthur, J. B. (1994). Effects of human resource management systems on manufacturing performance and turnover. Academy of Management Journal, 37, 670-687. doi:10.2307/256705

Bamberger, P., \& Meshoulam, I. (2000). Human resource strategy. Thousand Oaks, CA: Sage.

Bamberger, P., \& Phillips, B. (1991). Organizational environment and business strategy: Parallel versus conflicting influences on human resource strategy in the pharmaceutical industry. Human Resource Management, 30, 153-182. doi:10.1002/hrm.3930300202 
*Baron, J. N., Hannan, M. T., \& Burton, M. D. (2001). Labor pains: Change in organizational models and employee turnover in young hightech firms. American Journal of Sociology, 106, 960-1012. doi:10.1086/ 320296

*Batt, R. (2002). Managing customer services: Human resource practices, quit rates, and sales growth. Academy of Management Journal, 45, 587-597. doi:10.2307/3069383

*Batt, R., \& Colvin, A. J. S. (2011). An employment systems approach to turnover: HR practices, quits, dismissals, and performance. Academy of Management Journal, 54, 695-717. doi:10.5465/AMJ.2011.64869448

*Bingley, P., \& Westergaard-Nielsen, N. (2004). Personnel policy and profit. Journal of Business Research, 57, 557-563. doi:10.1016/S01482963(02)00321-1

*Bird, A., \& Beechler, S. (1995). Links between business strategy and human resource management strategy in U.S.-based Japanese subsidiaries: An empirical investigation. Journal of International Business Studies, 26, 23-46. doi:10.1057/palgrave.jibs. 8490164

Bommer, W. H., Johnson, J. L., Rich, G. A., Podsakoff, P. M., \& Mackenzie, S. B. (1995). On the interchangeability of objective and subjective measures of employee performance: A meta-analysis. Personnel Psychology, 48, 587-605. doi:10.1111/j.1744-6570.1995.tb01772.x

*Boselie, P., Paauwe, P., \& Richardson, R. (2003). Human resource management, institutionalization and organizational performance: A comparison of hospitals, hotels and local government. The International Journal of Human Resource Management, 14, 1407-1429. doi:10.1080/ 0958519032000145828

Boswell, W. R., Boudreau, J. W., \& Tichy, J. (2005). The relationship between employee job change and job satisfaction: The honeymoonhangover effect. Journal of Applied Psychology, 90, 882-892. doi: 10.1037/0021-9010.90.5.882

*Boyne, G. A., James, O., John, P., \& Petrovsky, N. (2011). Top management turnover and organizational performance: A test of a contingency model. Public Administration Review, 71, 572-581. doi:10.1111/j.15406210.2011.02389.x

Brookman, J. T., Chang, S., \& Rennie, C. G. (2007). CEO cash and stock-based compensation changes, layoff decisions, and shareholder value. Financial Review, 42, 99-119. doi:10.1111/j.1540-6288.2007 .00163.x

*Brown, S., Garino, G., \& Martin, C. (2009). Firm performance and labour turnover: Evidence from the 2004 workplace employee relations survey. Economic Modeling, 26, 689-695. doi:10.1016/j.econmod.2009.01.014

Cameron, K. S., Whetton, D. A., \& Kim, M. U. (1987). Organizational dysfunctions of decline. Academy of Management Journal, 30, 126-138. doi: $10.2307 / 255899$

Campion, M. A. (1991). Meaning and measurement of turnover: Comparison of alternative measures and recommendations for research. Journal of Applied Psychology, 76, 199-212. doi:10.1037/0021-9010.76.2.199

*Cannella, A. A., Jr., \& Hambrick, D. C. (1993). Effects of executive departures on the performance of acquired firms. Strategic Management Journal, 14, 137-152. doi:10.1002/smj.4250140911

Carley, K. (1992). Organizational learning and personnel turnover. Organization Science, 3, 20-46. doi:10.1287/orsc.3.1.20

Cascio, W. F. (1993). Downsizing: What do we know? What have we learned? Academy of Management Executive, 7, 95-103.

Cascio, W. F., \& Young, C. E. (2003). Financial consequences of employment-change decisions in major U. S. corporations, 1982-2000. In K. P. De Meuse \& M. L. Marks (Eds.), Resizing the organization: Managing layoffs, divestitures, and closings (pp. 131-156). San Francisco, CA: Jossey-Bass.

Cascio, W. F., Young, C. E., \& Morris, J. R. (1997). Financial consequences of employment-change decisions in major U.S. corporations. Academy of Management Journal, 40, 1175-1189. doi:10.2307/256931
*Chadwick, C., Hunter, L. W., \& Walston, S. L. (2004). Effects of downsizing practices on the performance of hospitals. Strategic Management Journal, 25, 405-427. doi:10.1002/smj.383

Chalos, P., \& Chen, C. J. P. (2002). Employee downsizing strategies: Market reaction and post announcement financial performance. Journal of Business Finance \& Accounting, 29, 847-870. doi:10.1111/14685957.00453

*Chi, W., \& Wang, Y. (2009). Ownership, performance and executive turnover in China. Journal of Asian Economics, 20, 465-478. doi: 10.1016/j.asieco.2009.04.009

*Chow, I. H. S., Huang, J. C., \& Liu, S. (2008). Strategic HRM in China: Configurations and competitive advantage. Human Resource Management, 47, 687-706. doi:10.1002/hrm.20240

*Chow, I. H. S., \& Liu, S. (2009). The effect of aligning organizational culture and business strategy with HR systems on firm performance in Chinese enterprises. The International Journal of Human Resource Management, 20, 2292-2310. doi:10.1080/09585190903239666

*Cooil, B., Aksoy, L., Keiningham, T. L., \& Maryott, K. M. (2009). The relationship of employee perceptions of organizational climate to business-unit outcomes: An MPLS approach. Journal of Service Research, 11, 277-294. doi:10.1177/1094670508328984

Crook, T. R., Todd, S. Y., Combs, J. G., Woehr, D. J., \& Ketchen, D. J. (2011). Does human capital matter? A meta-analysis of the relationship between human capital and firm performance. Journal of Applied Psychology, 96, 443-456. doi:10.1037/a0022147

Dalton, D. R., Daily, C. M., Ellstrand, A. E., \& Johnson, J. L. (1998). Meta-analytic reviews of board composition, leadership structure, and financial performance. Strategic Management Journal, 19, 269-290. doi:10.1002/(SICI)1097-0266(199803)19:3<269::AID-SMJ950>3.0 .CO;2-K

Dalton, D. R., Daily, C. M., Johnson, J. L., \& Ellstrand, A. E. (1999). Number of directors and financial performance: A meta-analysis. Academy of Management Journal, 42, 674-686. doi:10.2307/256988

Dalton, D. R., \& Todor, W. D. (1979). Turnover turned over: An expanded and positive perspective. Academy of Management Review, 4, 225-235.

Dalton, D. R., Todor, W. D., \& Krackhardt, D. M. (1982). Turnover overstated: The functional taxonomy. Academy of Management Review, 7, 117-123.

Datta, D. K., Guthrie, J. P., Basuil, D., \& Pandey, A. (2010). Causes and effects of employee downsizing: A review and synthesis. Journal of Management, 36, 281-348. doi:10.1177/0149206309346735

Datta, D. K., Guthrie, J. P., \& Wright, P. M. (2005). HRM and labor productivity: Does industry matter? Academy of Management Journal, 48, 135-145. doi:10.5465/AMJ.2005.15993158

Delery, J. E., \& Shaw, J. D. (2001). The strategic management of people in work organizations: Review, synthesis, and extension. Research in Personnel and Human Resources Management, 20, 165-197. doi: 10.1016/S0742-7301(01)20003-6

Dess, G. G., \& Shaw, J. D. (2001). Voluntary turnover, social capital, and organizational performance. Academy of Management Review, 26, 446456.

*Detert, J. R., Trevino, L. K., Burris, E. R., \& Andiappan, M. (2007). Managerial modes of influence and counterproductivity in organizations: A longitudinal business-unit-level investigation. Journal of Applied Psychology, 92, 993-1005. doi:10.1037/0021-9010.92.4.993

Dewitt, R. (1998). Firm, industry, and strategy influences on choice of downsizing approach. Strategic Management Journal, 19, 59-79. doi: 10.1002/(SICI)1097-0266(199801)19:1<59::AID-SMJ934>3.0.CO; $2-2$

*Donoghue, C. (2010). Nursing home staff turnover and retention: An analysis of national level data. Journal of Applied Gerontology, 29, 89-106. doi:10.1177/0733464809334899

Erez, A., Bloom, M. C., \& Wells, M. T. (1996). Using random rather than fixed effects models in meta-analysis: Implications for situational spec- 
ificity and validity generalization. Personnel Psychology, 49, 275-306. doi:10.1111/j.1744-6570.1996.tb01801.x

*Ericksen, J. (2011, August). Unit-level retention and productivity: Implications of employee engagement and customer demand. Paper presented at the annual meeting of the Academy of Management, San Antonio, TX.

*Eriksen, B. H. (2011a). Employee turnover and work quality. Working paper, University of Southern Denmark, Odense.

*Eriksen, B. H. (2011b). Growing pains: How employee turnover affects firm performance. Working paper, University of Southern Denmark, Odense.

*Faems, D., Sels, L., Winne, S. D., \& Maes, J. (2005). The effect of individual HR domains on financial performance: Evidence from Belgian small businesses. The International Journal of Human Resource Management, 16, 676-700. doi:10.1080/09585190500082790

Field, A. P. (2001). Meta-analysis of correlation coefficients: A Monte Carlo comparison of fixed- and random-effects methods. Psychological Methods, 6, 161-180. doi:10.1037/1082-989X.6.2.161

Flanagan, D. J., \& O'Shaughnessy, K. C. (2005). The effect of layoffs on firm reputation. Journal of Management, 31, 445-463. doi:10.1177/ 0149206304272186

*Flood, P. C., Guthrie, J. P., Armstrong, C., MacCurtain, S., \& Mkamwa, T. (2010). Partnership climate, high performance work systems and organizational effectiveness. Paper presented at the annual meeting of the Academy of Management, Montreal, Quebec, Canada.

Freeman, S. J., \& Cameron, K. (1993). Organizational downsizing: A convergence and reorientation framework. Organization Science, 4, 10-29. doi: $10.1287 /$ orsc. 4.1 .10

Freund, P. A., \& Kasten, N. (2012). How smart do you think you are? A meta-analysis on the validity of self-estimates of cognitive ability. Psychological Bulletin, 138, 296-321. doi:10.1037/a0026556

*Galang, M. C. (2004). The transferability question: Comparing HRM practices in the Philippines with the U.S. and Canada. The International Journal of Human Resource Management, 15, 1207-1233. doi:10.1080/ 0958519042000238419

*Gelade, G. A., \& Ivery, M. (2003). The impact of human resource management and work climate on organizational performance. Personnel Psychology, 56, 383-404. doi:10.1111/j.1744-6570.2003.tb00155.x

*George, J. M., \& Bettenhausen, K. (1990). Understanding prosocial behavior, sales performance, and turnover: A group-level analysis in a service context. Journal of Applied Psychology, 75, 698-709. doi: 10.1037/0021-9010.75.6.698

Gerhart, B., \& Rynes, S. L. (2003). Compensation: Theory, evidence, and strategic implications. Thousand Oaks, CA: Sage.

Geyskens, I., Steenkamp, J. E. M., \& Kumar, N. (2006). Make, buy, or ally: A transaction cost theory meta-analysis. Academy of Management Journal, 49, 519-543. doi:10.5465/AMJ.2006.21794670

*Ghebregiorgis, F., \& Karsten, L. (2007). Human resource management and performance in a developing country: The case of Eritrea. The International Journal of Human Resource Management, 18, 321-332. doi:10.1080/09585190601102547

*Glebbeek, A. C., \& Bax, E. H. (2004). Is high employee turnover really harmful? An empirical test using company records. Academy of Management Journal, 47, 277-286. doi:10.2307/20159578

*Goins, S., \& Gruca, T. S. (2008). Understanding competitive and contagion effects of layoff announcements. Corporate Reputation Review, 11, 12-34. doi: $10.1057 / \mathrm{crr} .2008 .3$

Green, S. G., Anderson, S. E., \& Shivers, S. L. (1996). Demographic and organizational influences on leader-member exchange and related work attitudes. Organizational Behavior and Human Decision Processes, 66, 203-214. doi:10.1006/obhd.1996.0049

Greenwald, A. G., Poehlman, T. A., Uhlmann, E., \& Banaji, M. R. (2009). Understanding and using the Implicit Association Test: III. Meta- analysis of predictive validity. Journal of Personality and Social Psychology, 97, 17-41. doi:10.1037/a0015575

*Griffith, J. (2006). A compositional analysis of the organizational climateperformance relation: Public schools as organizations. Journal of Applied Social Psychology, 36, 1848-1880. doi:10.1111/j.0021-9029.2006 .00085.x

*Guest, D., Conway, N., \& Dewe, P. (2004). Using sequential tree analysis to search for "bundles" of HR practices. Human Resource Management Journal, 14, 79-96. doi:10.1111/j.1748-8583.2004.tb00113.x

*Guest, D. E., Michie, J., Conway, N., \& Sheehan, M. (2003). Human resource management and corporate performance in the UK. British Journal of Industrial Relations, 41, 291-314. doi:10.1111/1467-8543 .00273

*Guthrie, J. P. (2001). High-involvement work practices, turnover, and productivity: Evidence from New Zealand. Academy of Management Journal, 44, 180-190. doi:10.2307/3069345

*Guthrie, J. P., \& Datta, D. K. (2008). Dumb and dumber: The impact of downsizing on firm performance as moderated by industry conditions. Organization Science, 19, 108-123. doi:10.1287/orsc.1070.0298

*Guthrie, J. P., Datta, D. K., \& Wadhwa, P. (2010). High performance work systems in low-wage America: Industry wages, HRM and employee turnover. Paper presented at the annual meeting of the Academy of Management, Montreal, Quebec, Canada.

*Guthrie, J. P., Flood, P. C., Liu, W., \& MacCurtain, S. (2009). High performance work systems in Ireland: Human resource and organizational outcomes. The International Journal of Human Resource Management, 20, 112-125. doi:10.1080/09585190802528433

Hallock, K. F. (1998). Layoffs, top executive pay, and firm performance American Economic Review, 88, 711-723.

Hambrick, D. C., \& Mason, P. A. (1984). Upper echelons: The organization as a reflection of its top managers. The Academy of Management Review, 9, 193-206.

*Hansson, B. (2007). Company-based determinants of training and the impact of training on company performance: Results from an international HRM survey. Personnel Review, 36, 311-331. doi:10.1108/ 00483480710726163

Harter, J. K., Schmidt, F. L., \& Hayes, T. L. (2002). Business-unit-level relationship between employee satisfaction, employee engagement, and business outcomes: A meta-analysis. Journal of Applied Psychology, 87, 268-279. doi:10.1037/0021-9010.87.2.268

*Hatch, N. W., \& Dyer, J. H. (2004). Human capital and learning as a source of sustainable competitive advantage. Strategic Management Journal, 25, 1155-1178. doi:10.1002/smj.421

Hausknecht, J. P., \& Holwerda, J. A. (2012). When does employee turnover matter? Dynamic member configurations, productive capacity, and collective performance. Organization Science. Advance online publication doi: $10.1287 /$ orsc 1110.0720

Hausknecht, J. P., \& Trevor, C. O. (2011). Collective turnover at the group, unit, and organizational levels: Evidence, issues, and implications. Journal of Management, 37, 352-388. doi:10.1177/0149206310383910

*Hausknecht, J. P., Trevor, C. O., \& Howard, M. J. (2009). Unit-level turnover rates and customer service quality: Implications for group cohesiveness, newcomer concentration, and size. Journal of Applied Psychology, 94, 1068-1075. doi:10.1037/a0015898

Hedges, L. V., \& Olkin, I. (1985). Statistical methods for meta-analysis. Orlando, FL: Academic Press.

Hedges, L. V., \& Vevea, J. L. (1998). Fixed- and random-effects models in meta-analysis. Psychological Methods, 3, 486-504. doi:10.1037/1082989X.3.4.486

Heugens, P. P. M. A. R., \& Lander, M. W. (2009). Structure! Agency! (And other quarrels): A meta-analysis of institutional theories of organization. Academy of Management Journal, 52, 61-85. doi:10.5465/ AMJ.2009.36461835 
Hofstede, G. (1980). Culture's consequences: International differences in work-related values. Newbury Park, CA: Sage.

Hollenbeck, J. R., \& Williams, C. R. (1986). Turnover functionality versus turnover frequency: A note on work attitudes and organizational effectiveness. Journal of Applied Psychology, 71, 606-611. doi:10.1037/ 0021-9010.71.4.606

*Holman, D., Frenkel, S., Sørensen, O., \& Wood, S. (2009). Work design variation and outcomes in call centers: Strategic choice and institutional explanations. Industrial and Labor Relations Review, 62, 510-532.

Holtom, B. C., Mitchell, T. R., Lee, T. W., \& Eberly, M. B. (2008). Turnover and retention research: A glance at the past, a closer review of the present, and a venture into the future. The Academy of Management Annals, 2, 231-274. doi:10.1080/19416520802211552

Hom, P. W., Tsui, A. S., Wu, J. B., \& Lee, T. W. (2009). Explaining employment relationships with social exchange and job embeddedness. Journal of Applied Psychology, 94, 277-297. doi:10.1037/a0013453

Hunter, J. E., \& Schmidt, F. L. (2004). Methods of meta-analysis: Correcting error and bias in Lepak \& Snell (1999) research findings. Thousand Oaks, CA: Sage.

*Huselid, M. A. (1995). The impact of human resource management practices on turnover, productivity, and corporate financial performance. Academy of Management Journal, 38, 635-672. doi:10.2307/256741

Jeswald, T. A. (1974). The cost of absenteeism and turnover in a large organization. In W. C. Hamner \& F. L. Schmidt (Eds.), Contemporary problems in personnel: Readings for the seventies (pp. 352-357). Chicago, IL: St.Clair Press.

Judge, T. A., Thoresen, C. J., Bono, J. E., \& Patton, G. K. (2001). The job satisfaction-job performance relationship: A qualitative and quantitative review. Psychological Bulletin, 127, 376-407. doi:10.1037/0033-2909 .127.3.376

Kacmar, K. M., Andrews, M. C., Van Rooy, D., Steilberg, C., \& Cerrone, S. (2006). Sure everyone can be replaced ... but at what cost? Turnover as a predictor of unit-level performance. Academy of Management Journal, 49, 133-144. doi:10.5465/AMJ.2006.20785670

*Keck, S. L. (1997). Top management team structure: Differential effects by environmental context. Organization Science, 8, 143-156. doi: 10.1287/orsc.8.2.143

Kesner, I. F., \& Dalton, D. R. (1994). Top management turnover and CEO succession: An investigation of the effects of turnover on performance. Journal of Management Studies, 31, 701-713. doi:10.1111/j.1467-6486 .1994.tb00635.x

*Kim, Y., \& Park, J.-H. (2011). The very first succession: Founder-CEO turnover and its consequences. Paper presented at the annual meeting of the Academy of Management, San Antonio, TX.

Kirca, A. H., Hult, G. T. M., Roth, K., Cavusgil, S. T., Perry, M., Akdeniz, M. B., . . White, R. C. (2011). Firm-specific assets, multinationality, and financial performance: A meta-analytic review and theoretical integration. Academy of Management Journal, 54, 47-72. doi:10.5465/AMJ 2011.59215090

*Koslowksy, M., \& Locke, G. (1989). Turnover and aggregate organizational performance. Applied Psychology: An International Review, 38, 121-129. doi:10.1111/j.1464-0597.1989.tb01204.x

*Koys, D. J. (2001). The effects of employee satisfaction, organizational citizenship behavior, and turnover on organizational effectiveness: A unit-level, longitudinal study. Personnel Psychology, 54, 101-114. doi: 10.1111/j.1744-6570.2001.tb00087.x

Kozlowski, S. W. J., \& Bell, B. S. (2003). Work groups and teams in organizations. In W. C. Borman, D. R. Ilgen, \& R. J. Klimski (Eds.), Handbook of psychology: Vol. 12. Industrial and organizational psychology (pp. 333-375). Hoboken, NJ: Wiley.

*Krishnan, H. A., Hitt, M. A., \& Park, D. (2007). Acquisitions premiums, subsequent work force reductions, and post-acquisition performance. Journal of Management Studies, 44, 709-732. doi:10.1111/j.1467-6486 .2006.00672.x
Leana, C. R., \& Van Buren, H. J., III. (1999). Organizational social capital and employment practices. Academy of Management Review, 24, 538 555.

Lee, P. M. (1997). A comparative analysis of layoff announcements and stock price reactions in the United States and Japan. Strategic Management Journal, 18, 879-894. doi:10.1002/(SICI)1097-0266(199712)18: $11<879::$ AID-SMJ929>3.0.CO;2-V

Lepak, D. P., \& Shaw, J. D. (2008). Strategic HRM in North America: Looking to the future. International Journal of Human Resource Management, 19, 1486-1499. doi:10.1080/09585190802200272

Lepak, D. P., \& Snell, S. A. (1999). The human resource architecture: Toward a theory of human capital allocation and development. Academy of Management Review, 24, 31-48.

Lepak, D. P., Taylor, M. S., Tekleab, A., Marrone, J. A., \& Cohen, D. J. (2007). An examination of the use of high-investment human resource systems for core and support employees. Human Resource Management, 46, 223-246. doi:10.1002/hrm.20158

*Leveck, M. L., \& Jones, C. B. (1996). The nursing practice environment, staff retention, and quality of care. Research in Nursing and Health, 19, 331-343. doi:10.1002/(SICI)1098-240X(199608)19:4<331::AIDNUR7 $>3.0 . \mathrm{CO} ; 2-\mathrm{J}$

Lipsey, M. W., \& Wilson, D. B. (2001). Practical meta-analysis. Thousand Oaks, CA: Sage.

Love, E. G., \& Nohria, N. (2005). Reducing slack: The performance consequences of downsizing by large industrial firms, 1977-93. Strategic Management Journal, 26, 1087-1108. doi:10.1002/smj.487

*Lynn, M. (2002). Turnover's relationships with sales, tips and service across restaurants in a chain. Hospitality Management, 21, 443-447. doi:10.1016/S0278-4319(02)00026-9

*MacKenzie, S. B., Podsakoff, P. M., \& Podsakoff, N. P. (2011). Citizenship behaviors and organizational effectiveness: Do challenge-oriented behaviors really have an impact on the organization's bottom line? Personnel Psychology, 64, 559-592.

*McElroy, J. C., Morrow, P. C., \& Rude, S. C. (2001). Turnover and organizational performance: A comparative analysis of voluntary, involuntary, and reduction-in-force turnover. Journal of Applied Psychology, 86, 1294-1299. doi:10.1037/0021-9010.86.6.1294

*Meier, K. J., \& Hicklin, A. (2007). Employee turnover and organizational performance: Testing a hypothesis from classical public administration. Journal of Public Administration Research and Theory, 18, 573-590. doi:10.1093/jopart/mum028

*Meier, K. J., Mastracci, S. H., \& Wilson, K. (2006). Gender and emotional labor in public organizations: An empirical examination of the link to performance. Public Administration Review, 66, 899-909. doi: 10.1111/j.1540-6210.2006.00657.x

*Messersmith, J. G., \& Guthrie, J. P. (2010). High performance work systems in emergent organizations: Implications for firm performance. Human Resource Management, 49, 241-264. doi:10.1002/hrm.20342

*Messersmith, J. G., Guthrie, J. P., \& Ji, Y.-Y. (2010). Turnover at the top: Executive team departures and firm performance. Working paper, University of Kansas, Lawrence.

*Miah, M. K., \& Bird, A. (2007). The impact of culture on HRM styles and firm performance: Evidence from Japanese parents, Japanese subsidiaries/joint ventures and South Asian local companies. The International Journal of Human Resource Management, 18, 908-923. doi:10.1080/ 09585190701249537

*Mohr, D. C., Young, G. J., \& Burgess, J. F., Jr. (2012). Employee turnover and operational performance: The moderating effect of grouporiented organisational culture. Human Resource Management Journal, 22, 216-233. doi:10.1111/j.1748-8583.2010.00159.x

Morrow, P., \& McElroy, J. (2007). Efficiency as a mediator in turnoverorganizational performance relations. Human Relations, 60, 827-849. doi: $10.1177 / 0018726707080078$ 
*Mueller, C. W., \& Price, J. (1989). Some consequences of turnover: A work unit analysis. Human Relations, 42, 389-402. doi:10.1177/ 001872678904200502

Nickell, S. (1997). Unemployment and labor market rigidities: Europe versus North America. Journal of Economic Perspectives, 11, 55-74. doi:10.1257/jep.11.3.55

*Nixon, R. D., Hitt, M. A., Lee, H., \& Jeong, E. (2004). Market reactions to announcements of corporate downsizing actions and implementation strategies. Strategic Management Journal, 25, 1121-1129. doi:10.1002/ smj. 423

Nyberg, A., \& Ployhart, R. (2012). Context-emergent turnover theory (CETT): A theory of collective turnover. Academy of Management Review. Advance online publication. doi:10.5465/amr.2011.0201

Osterman, P. (1987). Turnover, employment security, and the performance of the firm. In M. Kleiner (Ed.), Human resources and the performance of the firm (pp. 275-317). Madison, WI: Industrial Relations Research Association.

Palmon, O., Sun, H., \& Tang, A. (1997). Layoff announcements: Stock market impact and financial performance. Financial Management, 26, 54-68. doi:10.2307/3666213

*Park, T.-Y., \& Shaw, J. D. (2011). The impact of high performer turnover on organizational performance. Working paper, University of Minnesota, Minneapolis.

*Paul, A. K., \& Anantharaman, R. N. (2003). Impact of people management practices on organizational performance: Analysis of a causal model. The International Journal of Human Resource Management, 14, 1246-1266. doi:10.1080/0958519032000145648

Perry, T., \& Shivdasani, A. (2005). Do boards affect performance? Evidence from corporate restructuring. Journal of Business, 78, 1403-1432. doi: $10.1086 / 430864$

*Peterson, S. J., \& Luthans, F. (2006). The impact of financial and nonfinancial incentives on business-unit outcomes over time. Journal of Applied Psychology, 91, 156-165. doi:10.1037/0021-9010.91.1.156

Pfeffer, J. (1998). The human equation: Building profits by putting people first. Boston, MA: Harvard Business School Press.

Plomondon, M. E., Magid, D. J., Steiner, J. F., MaWhinney, S., Gifford, B. D., Shih, S. C., . . Rumsfeld, J. S. (2007). Primary care provider turnover and quality in managed care organizations. American Journal of Managed Care, 13, 465-472.

*Ployhart, R. E., Van Iddekinge, C. H., \& MacKenzie, W. I. (2011). Acquiring and developing human capital in service contexts: The interconnectedness of human capital resources. Academy of Management Journal, 54, 353-368. doi:10.5465/AMJ.2011.60263097

*Ployhart, R. E., Weekley, J. A., \& Ramsey, J. (2009). The consequences of human resource stocks and flows: A longitudinal examination of unit service orientation and unit effectiveness. Academy of Management Journal, 52, 996-1015. doi:10.5465/AMJ.2009.44635041

Prentice, D. A., \& Miller, D. T. (1992). When small effects are impressive. Psychological Bulletin, 112, 160-164. doi:10.1037/0033-2909.112.1 .160

Price, J. L. (1977). The study of turnover. Ames: Iowa State University Press.

Puffer, S. M., \& Weintrop, J. B. (1991). Corporate performance and CEO turnover: The role of performance expectations. Administrative Science Quarterly, 36, 1-19. doi:10.2307/2393427

*Richard, O. C., \& Johnson, N. B. (2001). Strategic human resource management effectiveness and firm performance. The International Journal of Human Resource Management, 12, 299-310.

Richard, P. J., Devinney, T. M., Yip, G. S., \& Johnson, G. (2009). Measuring organizational performance: Towards methodological best practice. Journal of Management, 35, 718-804. doi:10.1177/ 0149206308330560

*Richardson, H. A., \& Vandenberg, R. J. (2005). Integrating managerial perceptions and transformational leadership into a work-unit level model of employee involvement. Journal of Organizational Behavior, 26, 561-589. doi:10.1002/job.329

*Riordan, C. M., Vandenberg, R. J., \& Richardson, H. A. (2005). Employee involvement climate and organizational effectiveness. Human Resource Management, 44, 471-488. doi:10.1002/hrm.20085

Rothstein, H. R., Sutton, A. J., \& Borenstein, M. (Eds.). (2005). Publication bias in meta-analysis: Prevention, assessment and adjustments. doi:10. 1002/0470870168

*Ryan, A., Schmit, M. J., \& Johnson, R. (1996). Attitudes and effectiveness: Examining relations at an organizational level. Personnel Psychology, 49, 853-882. doi:10.1111/j.1744-6570.1996.tb02452.x

*Sacco, J. M., \& Schmitt, N. (2005). A dynamic multilevel model of demographic diversity and misfit effects. Journal of Applied Psychology, 90, 203-231. doi:10.1037/0021-9010.90.2.203

Schmidt, F. L., \& Hunter, J. E. (1996). Measurement error in psychological research: Lessons from 26 research scenarios. Psychological Methods, 1, 199-223. doi:10.1037/1082-989X.1.2.199

Schneider, B., Goldstein, H. W., \& Smith, D. B. (1995). The ASA framework: An update. Personnel Psychology, 48, 747-773. doi:10.1111/j .1744-6570.1995.tb01780.x

*Sels, L., De Winne, S., Maes, J., Delmotte, J., Faems, D., \& Forrier, A. (2006). Unraveling the HRM-performance link: Value-creating and costincreasing effects of small business HRM. Journal of Management Studies, 43, 319-342. doi:10.1111/j.1467-6486.2006.00592.x

Shadish, W. R., Cook, T. D., \& Campbell, D. T. (2001). Experimental and quasi-experimental designs for generalized causal inference. Belmont, CA: Wadsworth.

Shaw, J. D. (2011). Turnover rates and organizational performance: Review, critique, and research agenda. Organizational Psychology Review, 1, 187-213. doi:10.1177/2041386610382152

Shaw, J. D., Delery, J. E., Jenkins, G. D., \& Gupta, N. (1998). An organization-level analysis of voluntary and involuntary turnover. Academy of Management Journal, 41, 511-525. doi:10.2307/256939

Shaw, J. D., Dineen, B. R., Fang, R., \& Vellella, R. F. (2009). Employeeorganization exchange relationships, HRM practices, and quit rates of good and poor performers. Academy of Management Journal, 52, 10161033. doi:10.5465/AMJ.2009.44635525

*Shaw, J. D., Duffy, M. K., Johnson, J. L., \& Lockhart, D. E. (2005). Turnover, social capital losses, and performance. Academy of Management Journal, 48, 594-606. doi:10.5465/AMJ.2005.17843940

*Shaw, J. D., Gupta, N., \& Delery, J. E. (2005). Alternative conceptualizations of the relationship between voluntary turnover and organizational performance. Academy of Management Journal, 48, 50-68. doi: 10.5465/AMJ.2005.15993112

*Shaw, J. D., Park, T.-Y., \& Kim, E. (2012). A resource-based perspective on human capital losses, HRM investments, and organizational performance. Strategic Management Journal. Advance online publication. doi:10.1002/smj.2025

*Sheaffer, Z., Carmeli, A., Revivo, M., \& Zionit, S. (2009). How downsizing strategies affect organizational performance: A longitudinal study. Management Decision, 47, 950-974. doi:10.1108/00251740910966677

*Shen, W., \& Cannella, A. A., Jr. (2002). Revisiting the performance consequences of CEO succession: The impacts of successor types, postsuccession senior executive turnover, and departing CEO tenure Academy of Management Journal, 45, 717-733. doi:10.2307/3069306

Sheridan, J. E. (1985). A catastrophe model of employee withdrawal leading to low job performance, high absenteeism, and job turnover during the first year of employment. Academy of Management Journal, 28, 88-109. doi: $10.2307 / 256063$

*Shevchuk, I., Leana, C., \& Mittal, V. (2007). Employee retention and organizational performance: The mediating role of organization- and task-specific forms of human and social capital. Working paper, University of Pittsburgh, PA 
*Shortell, S. M., Zimmerman, J. E., Rousseau, D. M., Gillies, R. R., Wagner, D. P., Draper, E. A., . . Duffy, J. (1994). The performance of intensive care units: Does good management make a difference? Medical Care, 32, 508-525. doi:10.1097/00005650-199405000-00009

*Siebert, W. S., \& Zubanov, N. (2009). Searching for the optimal level of employee turnover: A study of a large U.K. retail organization. Academy of Management Journal, 52, 294-313. doi:10.5465/AMJ.2009 .37308149

*Siebert, W. S., \& Zubanov, N. (2010). Management economics in a large retail company. Management Science, 56, 1398-1414. doi:10.1287/ mnsc. 1100.1188

*Simon, C., De Sivatte, I., \& Olmos, R. (2012). The effects of collective quits and dismissals on performance in retail units: A panel data analysis. Working paper, IE Business School, Madrid, Spain.

*Sowinski, D. R., Fortmann, K. A., \& Lezotte, D. V. (2008). Climate for service and the moderating effects of climate strength on customer satisfaction, voluntary turnover, and profitability. European Journal of Work and Organizational Psychology, 17, 73-88. doi:10.1080/ 13594320701473065

*Stavrou, E. T. (2005). Flexible work bundles and organizational competitiveness: A cross-national study of the European work context. Journal of Organizational Behavior, 26, 923-947. doi:10.1002/job.356

Staw, B. M. (1980). The consequences of turnover. Journal of Occupational Behaviour, 1, 253-273.

Strober, M. H. (1990). Human capital theory: Implications for HR managers. Industrial Relations, 29, 214-239. doi:10.1111/j.1468-232X.1990 tb00752.x

*Subramony, M., \& Holtom, B. (2011a). Customer satisfaction as a mediator of the turnover-performance relationship. Working paper, Northern Illinois University, DeKalb.

* Subramony, M., \& Holtom, B. (2011b). The long-term influence of service employee attrition on customer outcomes and profits in a relationship-based business. Working paper, Northern Illinois University, DeKalb.

*Sun, L. Y., Aryee, S., \& Law, K. S. (2007). High-performance human resource practices, citizenship behaviour, and organizational performance: A relational perspective. Academy of Management Journal, 50, 558-577. doi:10.5465/AMJ.2007.25525821

*Takeuchi, R., Lepak, D. P., Wang, H., Shaw, J. D., \& Takeuchi, K. (2009). Ties that bind: Examining the impact of human and social capital on employee turnover and performance. Working paper, Hong Kong University of Science and Technology, Kowloon.

*Temkin-Greener, H., Zheng, N., Katz, P., Zhao, H., \& Mukamel, D. B. (2009). Measuring work environment and performance in nursing homes. Medical Care, 47, 482-491. doi:10.1097/MLR $.0 \mathrm{~b} 013 \mathrm{e} 318190 \mathrm{cfd} 3$

*Ton, Z., \& Huckman, R. S. (2008). Managing the impact of employee turnover on performance: The role of process conformance. Organization Science, 19, 56-68. doi:10.1287/orsc.1070.0294

*Tremblay, M., \& Chenevert, D. (2008). Influence of compensation strategies in Canadian technology-intensive firms on organizational and human resources performance. Group \& Organization Management, 33, 269-302. doi:10.1177/1059601107313310

Trevino, L. K. (1992). The social effects of punishment: A justice perspective. The Academy of Management Review, 17, 647-676.

Trevor, C. O. (2001). Interactions among actual ease-of-movement determinants and job satisfaction in the prediction of voluntary turnover. Academy of Management Journal, 44, 621-638. doi:10.2307/3069407

*Trevor, C. O., \& Nyberg, A. J. (2008). Keeping your headcount when all about you are losing theirs: Downsizing, voluntary turnover rates, and the moderating role of HR practices. Academy of Management Journal, 51, 259-276. doi:10.5465/AMJ.2008.31767250

Tsui, A. S., Pearce, J. L., Porter, L. W., \& Tripoli, A. M. (1997). Alternative approaches to the employee organization relationship: Does in- vestment in employees pay off? Academy of Management Journal, 40, 1089-1121. doi: $10.2307 / 256928$

*Vandenberg, R. J., Richardson, H. A., \& Eastman, L. J. (1999). The impact of high involvement work processes on organizational effectiveness: A second-order latent variable approach. Group \& Organization Management, 24, 300-339. doi:10.1177/1059601199243004

*Van der Vegt, G. S., Bunderson, S., \& Kuipers, B. (2010). Why turnover matters in self-managing work teams: Learning, social integration, and task flexibility. Journal of Management, 36, 1168-1191. doi:10.1177/ 0149206309344117

*Van Iddekinge, C. H., Ferris, G. R., Perrewé, P. L., Perryman, A. A., Blass, F. R., \& Heetderks, T. D. (2009). Effects of selection and training on unit-level performance over time: A latent growth modeling approach. Journal of Applied Psychology, 94, 829-843. doi:10.1037/ a0014453

*Van Jaarsveld, D. D., \& Yanadori, Y. (2011). Compensation management in outsourced service organizations and its implications for quit rates, absenteeism and workforce performance: Evidence from Canadian call centres. British Journal of Industrial Relations, 49, s1-s26. doi:10.1111/ j.1467-8543.2010.00816.x

*Verburg, R. M., Den Hartog, D. N., \& Koopman, P. L. (2007). Configurations of human resource management practices: A model and test of internal fit. The International Journal of Human Resource Management, 18, 184-208. doi:10.1080/09585190601102349

Virany, B., Tushman, M. L., \& Romanelli, E. (1992). Executive succession and organization outcomes in turbulent environments: An organization learning approach. Organization Science, 3, 72-91. doi:10.1287/orsc.3 .1 .72

Wagner, W. G., Pfeffer, J., \& O'Reilly, C. A., III. (1984). Organizational demography and turnover in top-management groups. Administrative Science Quarterly, 29, 74-92. doi:10.2307/2393081

*Watrous, K. M., Huffman, A. H., \& Pritchard, R. D. (2006). When coworkers and managers quit: The effects of turnover and shared values on performance. Journal of Business and Psychology, 21, 103-126. doi:10.1007/s10869-005-9021-2

*Way, S. A. (2002). High performance work systems and intermediate indicators of firm performance within the US small business sector. Journal of Management, 28, 765-785.

Wayhan, V. B., \& Werner, S. (2000). The impact of workforce reductions on financial performance: A longitudinal perspective. Journal of Management, 26, 341-363. doi:10.1177/014920630002600208

*Wiersema, M. F., \& Bantel, K. A. (1993). Top management team turnover as an adaptation mechanism: The role of the environment. Strategic Management Journal, 14, 485-504. doi:10.1002/smj.4250140702

*Wiersema, M. F., \& Bird, A. (1993). Organizational demography in Japanese firms: Group heterogeneity, individual dissimilarity, and top management team turnover. Academy of Management Journal, 36, $996-$ 1025. doi: $10.2307 / 256643$

Worrell, D. L., Davidson, W. N., \& Sharma, V. M. (1991). Layoff announcements and stockholder wealth. Academy of Management Journal, 34, 662-678. doi:10.2307/256410

*Yanadori, Y., \& Kato, T. (2007). Average employee tenure, voluntary turnover ratio, and labour productivity: Evidence from Japanese firms. The International Journal of Human Resource Management, 18, 18411857. doi:10.1080/09585190701570981

*Yanadori, Y., \& Kato, T. (2009). Work and family practices in Japanese firms: Their scope, nature and impact on employee turnover. The International Journal of Human Resource Management, 20, 439-456. doi: 10.1080/09585190802673494

Yu, G.-C., \& Park, J.-S. (2006). The effect of downsizing on the financial performance and employee productivity of Korean firms. International Journal of Manpower, 27, 230-250. doi:10.1108/01437720610672158 
*Zatzick, C. D., \& Iverson, R. D. (2006). High-involvement management and workforce reduction: Competitive advantage of disadvantage? Academy of Management Journal, 49, 999-1015. doi:10.5465/AMJ.2006.22798180

*Zheng, C. (2009). Keeping talents for advancing service firms in Asia. Journal of Service Management, 20, 482-502. doi:10.1108/09564230910995107
Zimmerman, S., Sloane, P. D., Eckert, J. K., Gruber-Baldini, A. L., Morgan, L. A., Hebel, J. R., . . . Chen, C. K. (2005). How good is assisted living? Findings and implications from an outcomes study. The Journals of Gerontology: Series B: Psychological Sciences and Social Sciences, 60, S195-S204. doi:10.1093/geronb/60.4.S195

\section{Appendix A}

\section{Summary of Studies and Samples Included in the Meta-Analysis}

\begin{tabular}{|c|c|c|c|c|c|c|c|c|}
\hline Article $^{a}$ & Sample & $\begin{array}{l}\text { Sample } \\
\text { size }\end{array}$ & Correlation & $\begin{array}{l}\text { Turnover } \\
\text { rates }\end{array}$ & $\begin{array}{l}\text { Turnover } \\
\text { type }^{b}\end{array}$ & $\begin{array}{l}\text { Performance } \\
\text { dimensions }\end{array}$ & $\begin{array}{l}\text { Employment } \\
\text { system }\end{array}$ & Industry \\
\hline $\begin{array}{l}\text { Allen et al. } \\
\text { (2010) }\end{array}$ & $\begin{array}{l}\text { Publicly traded HR } \\
\text { outsourcing firms }\end{array}$ & 67 & -.25 & .14 & Total & $\begin{array}{l}\text { Sales growth } \\
\text { (WP) }\end{array}$ & All & Service \\
\hline \multirow[t]{2}{*}{$\begin{array}{l}\text { Angle \& Perry } \\
\text { (1981) }\end{array}$} & $\begin{array}{l}\text { Bus service firms } \\
\text { in western } \\
\text { United States }\end{array}$ & 22 & .15 & & Voluntary & $\begin{array}{l}\text { Operating } \\
\text { expense per } \\
\text { revenue } \\
\text { vehicle } \\
\text { hour (FP) }\end{array}$ & All & Trucking \\
\hline & & 20 & .05 & & Voluntary & $\begin{array}{l}\text { Operating } \\
\text { expense per } \\
\text { employee } \\
\text { (FP) }\end{array}$ & All & Trucking \\
\hline $\begin{array}{l}\text { Armstrong et al. } \\
\text { (2010) }\end{array}$ & $\begin{array}{l}\text { Irish Times } 1,000 \\
\text { companies }\end{array}$ & 179 & -.37 & & Voluntary & $\begin{array}{l}\text { Revenue per } \\
\text { employees } \\
\text { (WP) }\end{array}$ & All & Multiple \\
\hline \multirow[t]{2}{*}{ Arthur (1994) } & U.S. steel minimills & 25 & -.16 & .05 & Total & Scrap rate $(\mathrm{Q})$ & Primary & Manufacturing \\
\hline & & 28 & -.08 & .05 & Total & $\begin{array}{l}\text { Labor hours } \\
\text { (WP) }\end{array}$ & Primary & Manufacturing \\
\hline $\begin{array}{l}\text { Baron et al. } \\
\quad(2001)\end{array}$ & $\begin{array}{l}\text { Young, high-tech } \\
\text { firms in } \\
\text { California }\end{array}$ & 58 & .03 & .14 & Total & $\begin{array}{l}\text { Annual } \\
\text { revenue } \\
\text { growth } \\
\text { (WP) }\end{array}$ & All & IT \\
\hline Batt (2002) & Call center & 326 & -.10 & .14 & Voluntary & Sales (WP) & Secondary & Service \\
\hline \multirow[t]{4}{*}{$\begin{array}{l}\text { Batt \& Colvin } \\
\quad \text { (2011) }\end{array}$} & U.S. call centers & 339 & -.14 & .15 & Voluntary & $\begin{array}{l}\text { Customer } \\
\text { satisfaction } \\
\text { (CS) }\end{array}$ & Secondary & Service \\
\hline & & 339 & -.12 & .10 & Involuntary & $\begin{array}{l}\text { Customer } \\
\text { satisfaction } \\
\text { (CS) }\end{array}$ & Secondary & Service \\
\hline & & 339 & -.16 & .25 & Total & $\begin{array}{l}\text { Customer } \\
\text { satisfaction } \\
\text { (CS) }\end{array}$ & Secondary & Service \\
\hline & & 339 & .21 & .41 & Executive & $\begin{array}{l}\text { Customer } \\
\text { satisfaction } \\
\text { (CS) }\end{array}$ & Secondary & Service \\
\hline \multirow{2}{*}{$\begin{array}{l}\text { Bingley \& } \\
\text { Westergaard- } \\
\text { Nielsen } \\
(2004)\end{array}$} & $\begin{array}{l}\text { Denmark IDA } \\
\quad \text { (labor market }\end{array}$ & 28,265 & .00 & .37 & Total & $\begin{array}{l}\text { Profit per } \\
\quad \text { worker (FP) }\end{array}$ & All & Multiple \\
\hline & & 28,265 & .00 & .37 & Total & $\begin{array}{l}\text { Value added } \\
\text { per worker } \\
\text { (FP) }\end{array}$ & All & Multiple \\
\hline
\end{tabular}


Appendix A (continued)

\begin{tabular}{|c|c|c|c|c|c|c|c|c|}
\hline Article $^{a}$ & Sample & $\begin{array}{l}\text { Sample } \\
\text { size }\end{array}$ & Correlation & $\begin{array}{l}\text { Turnover } \\
\text { rates }\end{array}$ & $\begin{array}{c}\text { Turnover } \\
\text { type }^{b}\end{array}$ & $\begin{array}{l}\text { Performance } \\
\text { dimensions }\end{array}$ & $\begin{array}{l}\text { Employment } \\
\text { system }\end{array}$ & Industry \\
\hline \multirow[t]{10}{*}{$\begin{array}{l}\text { Bird \& Beechler } \\
\quad \text { (1995) }\end{array}$} & \multirow[t]{10}{*}{$\begin{array}{l}\text { Japanese } \\
\text { subsidiaries in } \\
\text { the United States }\end{array}$} & 64 & -.31 & .06 & Total & $\begin{array}{l}\text { Performance } \\
\text { on parent } \\
\text { objectives } \\
\text { (OP) }\end{array}$ & Executives & Multiple \\
\hline & & 64 & -.23 & .06 & Total & $\begin{array}{l}\text { Subsidiary } \\
\text { profit (FP) }\end{array}$ & Executives & Multiple \\
\hline & & 64 & -.08 & .06 & Total & $\begin{array}{l}\text { Subsidiary } \\
\text { sales (WP) }\end{array}$ & Executives & Multiple \\
\hline & & 64 & -.24 & .06 & Total & $\begin{array}{l}\text { Overall } \\
\text { subsidiary } \\
\text { performance } \\
\text { (OP) }\end{array}$ & Executives & Multiple \\
\hline & & 64 & -.25 & .06 & Total & $\begin{array}{l}\text { Performance } \\
\text { vs. } \\
\text { competitors } \\
\text { (OP) }\end{array}$ & Executives & Multiple \\
\hline & & 64 & .05 & .11 & Total & $\begin{array}{l}\text { Performance } \\
\text { on parent } \\
\text { objectives } \\
\text { (OP) }\end{array}$ & Primary & Multiple \\
\hline & & 64 & -.17 & .11 & Total & $\begin{array}{l}\text { Subsidiary } \\
\text { profit (FP) }\end{array}$ & Primary & Multiple \\
\hline & & 64 & .03 & .11 & Total & $\begin{array}{l}\text { Subsidiary } \\
\text { sales (WP) }\end{array}$ & Primary & Multiple \\
\hline & & 64 & -.31 & .11 & Total & $\begin{array}{l}\text { Overall } \\
\text { subsidiary } \\
\text { performance } \\
\text { (OP) }\end{array}$ & Primary & Multiple \\
\hline & & 64 & -.11 & .11 & Total & $\begin{array}{l}\text { Performance } \\
\text { vs. } \\
\text { competitors } \\
\text { (OP) }\end{array}$ & Primary & Multiple \\
\hline \multirow[t]{2}{*}{$\begin{array}{l}\text { Boselie et al. } \\
\text { (2003) }\end{array}$} & \multirow[t]{2}{*}{$\begin{array}{l}\text { Companies in the } \\
\text { Netherlands }\end{array}$} & 132 & -.02 & .12 & Total & $\begin{array}{l}\% \text { absence } \\
\text { due to } \\
\text { illness } \\
\text { (EWA) }\end{array}$ & All & Multiple \\
\hline & & 132 & .16 & .12 & Total & $\begin{array}{l}\text { Average } \\
\text { number of } \\
\text { days of } \\
\text { absence } \\
\text { (EWA) }\end{array}$ & All & Multiple \\
\hline \multirow[t]{4}{*}{$\begin{array}{l}\text { Boyne et al. } \\
\text { (2011) }\end{array}$} & \multirow[t]{4}{*}{$\begin{array}{l}\text { English local } \\
\text { governments }\end{array}$} & 587 & -.17 & .19 & Total (t-1) & $\begin{array}{l}\text { Core service } \\
\text { performance } \\
\text { score }(\mathrm{OP})\end{array}$ & Executives & Government \\
\hline & & 587 & -.18 & .19 & Total (t-1) & $\begin{array}{l}\text { Core service } \\
\text { performance } \\
\text { score }(\mathrm{OP})\end{array}$ & Executives & Government \\
\hline & & 587 & -.14 & .18 & Total (t-2) & $\begin{array}{l}\text { Core service } \\
\text { performance } \\
\text { score }(\mathrm{OP})\end{array}$ & Executives & Government \\
\hline & & 587 & -.21 & .18 & Total (t-2) & $\begin{array}{l}\text { Core service } \\
\text { performance } \\
\text { score }(\mathrm{OP})\end{array}$ & Executives & Government \\
\hline $\begin{array}{l}\text { Brown et al. } \\
\text { (2009) }\end{array}$ & $\begin{array}{l}\text { Establishments in } \\
\text { the United } \\
\text { Kingdom }\end{array}$ & 1,900 & -.05 & .13 & Voluntary & $\begin{array}{l}\text { Financial } \\
\text { Performance } \\
\text { (FP) }\end{array}$ & All & Multiple \\
\hline
\end{tabular}

(Appendices continue) 
Appendix A (continued)

\begin{tabular}{|c|c|c|c|c|c|c|c|c|}
\hline Article $^{a}$ & Sample & $\begin{array}{c}\text { Sample } \\
\text { size }\end{array}$ & Correlation & $\begin{array}{l}\text { Turnover } \\
\text { rates }\end{array}$ & $\begin{array}{l}\text { Turnover } \\
\text { type }^{b}\end{array}$ & $\begin{array}{l}\text { Performance } \\
\text { dimensions }\end{array}$ & $\begin{array}{l}\text { Employment } \\
\text { system }\end{array}$ & Industry \\
\hline \multirow{9}{*}{$\begin{array}{l}\text { Cannella \& } \\
\text { Hambrick } \\
\text { (1993) }\end{array}$} & \multirow{9}{*}{$\begin{array}{l}\text { Post-acquisition } \\
\text { firms in the } \\
\text { United States }\end{array}$} & 96 & -.25 & .49 & Total & $\begin{array}{l}\text { Profitability } \\
\text { (t) (FP) }\end{array}$ & Executives & Multiple \\
\hline & & 96 & -.25 & .49 & Total & $\begin{array}{l}\text { Profitability } \\
\quad(t+4) \\
\text { (FP) }\end{array}$ & Executives & Multiple \\
\hline & & 96 & -.03 & .49 & Total & $\begin{array}{l}\text { Profitability } \\
\text { change (FP) }\end{array}$ & Executives & Multiple \\
\hline & & 96 & -.14 & .51 & Total & $\begin{array}{l}\text { Profitability } \\
\text { (t) (FP) }\end{array}$ & $\begin{array}{c}\text { Executives } \\
\text { (more- } \\
\text { senior) }\end{array}$ & Multiple \\
\hline & & 96 & -.25 & .51 & Total & $\begin{array}{l}\text { Profitability } \\
\quad(\mathrm{t}+4) \\
(\mathrm{FP})\end{array}$ & $\begin{array}{l}\text { Executives } \\
\text { (more- } \\
\text { senior) }\end{array}$ & Multiple \\
\hline & & 96 & -.12 & .51 & Total & $\begin{array}{l}\text { Profitability } \\
\text { change (FP) }\end{array}$ & $\begin{array}{l}\text { Executives } \\
\text { (more- } \\
\text { senior) }\end{array}$ & Multiple \\
\hline & & 96 & -.29 & .44 & Total & $\begin{array}{l}\text { Profitability } \\
\text { (t) (FP) }\end{array}$ & $\begin{array}{l}\text { Executives } \\
\text { (less- } \\
\text { senior) }\end{array}$ & Multiple \\
\hline & & 96 & -.08 & .44 & Total & $\begin{array}{l}\text { Profitability } \\
\quad(t+4) \\
(\mathrm{FP})\end{array}$ & $\begin{array}{l}\text { Executives } \\
\quad \text { (less- } \\
\text { senior) }\end{array}$ & Multiple \\
\hline & & 96 & .13 & .44 & Total & $\begin{array}{l}\text { Profitability } \\
\text { change (FP) }\end{array}$ & $\begin{array}{l}\text { Executives } \\
\text { (less- } \\
\text { senior) }\end{array}$ & Multiple \\
\hline \multirow[t]{2}{*}{$\begin{array}{l}\text { Chadwick et al. } \\
\text { (2004) }\end{array}$} & \multirow[t]{2}{*}{$\begin{array}{l}\text { Hospitals in the } \\
\text { United States }\end{array}$} & 58 & -.07 & .05 & RIF & $\begin{array}{l}\text { Cash margins } \\
\text { (t) (FP) }\end{array}$ & Primary & Hospital \\
\hline & & 58 & -.07 & .05 & RIF & $\begin{array}{l}\text { Cash margins } \\
(\mathrm{t}+1) \\
(\mathrm{FP})\end{array}$ & Primary & Hospital \\
\hline \multirow[t]{2}{*}{$\begin{array}{l}\text { Chi \& Wang } \\
\text { (2009) }\end{array}$} & \multirow[t]{2}{*}{ Chinese firms } & 8,291 & .01 & .02 & Involuntary & $\begin{array}{l}\text { Workforce } \\
\text { performance } \\
\text { (WP) }\end{array}$ & Executives & Multiple \\
\hline & & 8,291 & -.05 & .02 & Involuntary & $\begin{array}{l}\text { Financial } \\
\text { performance } \\
\text { (FP) }\end{array}$ & Executives & Multiple \\
\hline \multirow[t]{3}{*}{$\begin{array}{c}\text { Chow et al. } \\
\text { (2008) }\end{array}$} & \multirow[t]{3}{*}{ Chinese firms } & 241 & -.17 & .12 & Total & $\begin{array}{l}\text { Innovation } \\
(\mathrm{OP})\end{array}$ & All & Multiple \\
\hline & & 241 & -.06 & .12 & Total & $\begin{array}{l}\text { Sales growth } \\
\text { (WP) }\end{array}$ & All & Multiple \\
\hline & & 241 & -.01 & .12 & Total & $\begin{array}{l}\text { Profit growth } \\
\text { (FP) }\end{array}$ & All & Multiple \\
\hline $\begin{array}{l}\text { Chow \& Liu } \\
\text { (2009) }\end{array}$ & Chinese companies & 451 & -.18 & .15 & Total & $\begin{array}{l}\text { Overall } \\
\text { performance } \\
\text { (OP) }\end{array}$ & All & Multiple \\
\hline \multirow[t]{2}{*}{$\begin{array}{l}\text { Cooil et al. } \\
\text { (2009) }\end{array}$} & \multirow[t]{2}{*}{$\begin{array}{l}\text { Retail grocery } \\
\text { superstore in } \\
\text { Europe }\end{array}$} & 107 & -.21 & .11 & Total & $\begin{array}{l}\text { Customer } \\
\text { satisfaction } \\
\text { (CS) }\end{array}$ & All & Retail \\
\hline & & 107 & .10 & .11 & Total & $\begin{array}{l}\text { Revenue } \\
\text { (WP) }\end{array}$ & All & Retail \\
\hline \multirow[t]{4}{*}{$\begin{array}{l}\text { Detert et al. } \\
\text { (2007) }\end{array}$} & \multirow[t]{4}{*}{$\begin{array}{l}\text { U.S. Food-Co } \\
\text { restaurants }\end{array}$} & 265 & -.03 & .14 & Total & $\begin{array}{l}\text { Food loss } \\
\text { (WP) }\end{array}$ & Secondary & Restaurant \\
\hline & & 265 & -.10 & .14 & Total & $\begin{array}{l}\text { Operating } \\
\text { profit (FP) }\end{array}$ & Secondary & Restaurant \\
\hline & & 265 & -.19 & .14 & Total & $\begin{array}{l}\text { Customer } \\
\text { satisfaction } \\
\text { (CS) }\end{array}$ & Secondary & Restaurant \\
\hline & & 265 & -.07 & .02 & Total & $\begin{array}{l}\text { Food loss } \\
\text { (WP) }\end{array}$ & Primary & Restaurant \\
\hline
\end{tabular}


Appendix A (continued)

\begin{tabular}{|c|c|c|c|c|c|c|c|c|}
\hline Article $^{\mathrm{a}}$ & Sample & $\begin{array}{l}\text { Sample } \\
\text { size }\end{array}$ & Correlation & $\begin{array}{l}\text { Turnover } \\
\text { rates }\end{array}$ & $\begin{array}{l}\text { Turnover } \\
\text { type }^{\mathrm{b}}\end{array}$ & $\begin{array}{l}\text { Performance } \\
\text { dimensions }\end{array}$ & $\begin{array}{l}\text { Employment } \\
\text { system }\end{array}$ & Industry \\
\hline & & 265 & .02 & .02 & Total & $\begin{array}{l}\text { Operating } \\
\text { profit (FP) }\end{array}$ & Primary & Restaurant \\
\hline & & 265 & -.04 & .02 & Total & $\begin{array}{l}\text { Customer } \\
\text { satisfaction } \\
\text { (CS) }\end{array}$ & Primary & Restaurant \\
\hline \multirow[t]{3}{*}{$\begin{array}{l}\text { Donoghue } \\
\text { (2010) }\end{array}$} & $\begin{array}{l}\text { Nursing homes in } \\
\text { the United States }\end{array}$ & 1,051 & -.14 & .14 & Total & $\begin{array}{l}\text { Average } \\
\text { occupancy } \\
\text { (WP) }\end{array}$ & All & Hospital \\
\hline & & 1,039 & -.06 & .13 & Total & $\begin{array}{l}\text { Average } \\
\text { occupancy } \\
\text { (WP) }\end{array}$ & Secondary & Hospital \\
\hline & & 1,028 & -.11 & .19 & Total & $\begin{array}{l}\text { Average } \\
\text { occupancy } \\
\text { (WP) }\end{array}$ & Secondary & Hospital \\
\hline Eriksen (2011a) & Danish firms & 2,926 & -.10 & .17 & Total & $\begin{array}{l}\text { Value added } \\
\text { (FP) }\end{array}$ & All & Manufacturing \\
\hline \multirow[t]{2}{*}{ Eriksen (2011b) } & Danish firms & 2,921 & -.04 & .17 & Total & $\begin{array}{l}\text { Labor } \\
\text { productivity } \\
\text { (WP) }\end{array}$ & All & Manufacturing \\
\hline & & 2,921 & -.01 & .17 & Total & $\mathrm{ROA}(\mathrm{FP})$ & All & Manufacturing \\
\hline Ericksen (2011) & $\begin{array}{l}\text { Units of a large } \\
\text { home } \\
\text { improvement } \\
\text { retailer }\end{array}$ & 808 & -.17 & .28 & Total & $\begin{array}{l}\text { Productivity } \\
\text { (WP) }\end{array}$ & All & Retail \\
\hline \multirow[t]{5}{*}{$\begin{array}{l}\text { Faems et al. } \\
\qquad(2005)\end{array}$} & $\begin{array}{l}\text { Belgian small and } \\
\text { medium } \\
\text { enterprises }\end{array}$ & 416 & -.08 & .12 & Voluntary & $\begin{array}{l}\text { Value added } \\
\text { (FP) }\end{array}$ & All & Multiple \\
\hline & & 416 & -.03 & .12 & Voluntary & $\begin{array}{l}\text { Personnel } \\
\text { costs over } \\
\text { value added } \\
\text { (FP) }\end{array}$ & All & Multiple \\
\hline & & 416 & -.05 & .12 & Voluntary & $\begin{array}{l}\text { Acid ratio test } \\
\text { (FP) }\end{array}$ & All & Multiple \\
\hline & & 416 & -.07 & .12 & Voluntary & $\begin{array}{l}\text { Degree of } \\
\text { auto- } \\
\text { financing } \\
\text { (WP) }\end{array}$ & All & Multiple \\
\hline & & 416 & .02 & .12 & Voluntary & $\begin{array}{l}\text { Net } \\
\text { profitability } \\
\text { (FP) }\end{array}$ & All & Multiple \\
\hline $\begin{array}{l}\text { Flood et al. } \\
\text { (2010) }\end{array}$ & Irish organizations & 132 & -.17 & .01 & Voluntary & $\begin{array}{l}\text { Sales revenue } \\
\text { (WP) }\end{array}$ & All & Multiple \\
\hline Galang (2004) & $\begin{array}{l}\text { Companies in the } \\
\text { Philippines }\end{array}$ & 103 & -.22 & .08 & Voluntary & $\begin{array}{l}\text { Overall } \\
\text { performance } \\
\text { (OP) }\end{array}$ & All & Multiple \\
\hline \multirow[t]{3}{*}{$\begin{array}{l}\text { Gelade \& Ivery } \\
\quad \text { (2003) }\end{array}$} & $\begin{array}{l}\text { Branch Director } \\
\text { Group members } \\
\text { in bank branches }\end{array}$ & 136 & -.32 & .08 & Total & Sales (WP) & Primary & Banking \\
\hline & & 137 & -.57 & .08 & Total & $\begin{array}{l}\text { Customer } \\
\text { satisfaction } \\
\text { (CS) }\end{array}$ & Primary & Banking \\
\hline & & 137 & -.78 & .08 & Total & $\begin{array}{l}\text { Overall } \\
\text { performance } \\
\text { (OP) }\end{array}$ & Primary & Banking \\
\hline $\begin{array}{l}\text { George \& } \\
\text { Bettenhausen } \\
\text { (1990) }\end{array}$ & Retail stores & 33 & -.25 & .32 & Voluntary & Sales (WP) & Primary & Retail \\
\hline $\begin{array}{l}\text { Ghebregiorgis } \\
\text { \& Karsten } \\
\text { (2007) }\end{array}$ & Eritrea firms & 82 & -.03 & .05 & Voluntary & $\begin{array}{l}\text { Absenteeism } \\
\text { (EWA) }\end{array}$ & All & Manufacturing \\
\hline
\end{tabular}

(Appendices continue) 
Appendix A (continued)

\begin{tabular}{|c|c|c|c|c|c|c|c|c|}
\hline Article $^{a}$ & Sample & $\begin{array}{l}\text { Sample } \\
\text { size }\end{array}$ & Correlation & $\begin{array}{l}\text { Turnover } \\
\text { rates }\end{array}$ & $\begin{array}{l}\text { Turnover } \\
\text { type }^{\mathrm{b}}\end{array}$ & $\begin{array}{l}\text { Performance } \\
\text { dimensions }\end{array}$ & $\begin{array}{c}\text { Employment } \\
\text { system }\end{array}$ & Industry \\
\hline & & 82 & -.09 & .05 & Voluntary & $\begin{array}{l}\text { Grievance } \\
\text { filing } \\
\text { (EWA) }\end{array}$ & All & Manufacturing \\
\hline & & 82 & .01 & .05 & Voluntary & $\begin{array}{l}\text { Productivity } \\
\text { (WP) }\end{array}$ & All & Manufacturing \\
\hline \multirow[t]{8}{*}{$\begin{array}{l}\text { Glebbeek \& } \\
\quad \text { Bax (2004) }\end{array}$} & $\begin{array}{l}\text { Temporary job } \\
\text { agency }\end{array}$ & 110 & -.23 & .16 & $\begin{array}{l}\text { Total } \\
\quad(95-98)\end{array}$ & $\begin{array}{l}\text { Profitability } \\
\text { 95-98 (FP) }\end{array}$ & Primary & Service \\
\hline & & 110 & -.21 & .14 & $\begin{array}{l}\text { Total } \\
\quad(95-96)\end{array}$ & $\begin{array}{l}\text { Profitability } \\
\text { 95-98 (FP) }\end{array}$ & Primary & Service \\
\hline & & 110 & -.19 & .16 & $\begin{array}{l}\text { Total } \\
\quad(95-98)\end{array}$ & $\begin{array}{c}\text { Profitability } \\
95 \text { (FP) }\end{array}$ & Primary & Service \\
\hline & & 110 & -.12 & .14 & $\begin{array}{l}\text { Total } \\
\quad(95-96)\end{array}$ & $\begin{array}{l}\text { Profitability } \\
95 \text { (FP) }\end{array}$ & Primary & Service \\
\hline & & 110 & -.21 & .16 & $\begin{array}{l}\text { Total } \\
\quad(95-98)\end{array}$ & $\begin{array}{l}\text { Profitability } \\
\text { 96-98 (FP) }\end{array}$ & Primary & Service \\
\hline & & 110 & -.22 & .14 & $\begin{array}{l}\text { Total } \\
\quad(95-96)\end{array}$ & $\begin{array}{l}\text { Profitability } \\
\text { 96-98 (FP) } \\
\text { averaged } \\
\text { with 97-98 }\end{array}$ & Primary & Service \\
\hline & & 110 & -.18 & .16 & $\begin{array}{l}\text { Total } \\
\quad(95-98)\end{array}$ & $\begin{array}{l}\text { Profitability } \\
\text { 97-98 (FP) }\end{array}$ & Primary & Service \\
\hline & & 110 & -.15 & .14 & $\begin{array}{l}\text { Total } \\
\quad(95-96)\end{array}$ & $\begin{array}{l}\text { Profitability } \\
\text { 97-98 (FP) }\end{array}$ & Primary & Service \\
\hline \multirow[t]{2}{*}{$\begin{array}{l}\text { Goins \& Gruca } \\
\quad(2008)\end{array}$} & $\begin{array}{l}\text { U.S. petroleum } \\
\text { industry firms }\end{array}$ & 57 & .01 & .07 & RIF & $\begin{array}{l}\text { 1-day stock } \\
\text { price }(\mathrm{FP})\end{array}$ & All & Petroleum \\
\hline & & 57 & -.20 & .07 & RIF & $\begin{array}{l}10 \text {-day stock } \\
\text { price }(\mathrm{FP})\end{array}$ & All & Petroleum \\
\hline \multirow[t]{2}{*}{ Griffith (2006) } & Elementary schools & 117 & -.07 & .24 & Voluntary & $\begin{array}{l}\text { Aggregated } \\
\text { job } \\
\text { satisfaction } \\
\text { (EWA) }\end{array}$ & Primary & Education \\
\hline & & 117 & -.27 & .24 & Voluntary & $\begin{array}{l}\text { Achievement } \\
\text { test score } \\
\text { (WP) }\end{array}$ & Primary & Education \\
\hline $\begin{array}{l}\text { Guest et al. } \\
\text { (2004) }\end{array}$ & U.K. companies & 1,308 & -.26 & .03 & Total & $\begin{array}{l}\text { Workforce } \\
\text { performance } \\
\text { (WP) }\end{array}$ & All & Multiple \\
\hline \multirow[t]{4}{*}{$\begin{array}{l}\text { Guest et al. } \\
\quad(2003)\end{array}$} & U.K. companies & 366 & -.08 & & Total & $\begin{array}{l}\text { Productivity } \\
00-01 \\
\text { (WP) }\end{array}$ & All & Multiple \\
\hline & & 366 & -.09 & & Total & $\begin{array}{l}\text { Productivity } \\
\text { 97-99 } \\
\text { (WP) }\end{array}$ & All & Multiple \\
\hline & & 366 & -.05 & & Total & $\begin{array}{l}\text { Profit } 00-01 \\
\text { (FP) }\end{array}$ & All & Multiple \\
\hline & & 366 & -.12 & & Total & $\begin{array}{l}\text { Profit 97-99 } \\
\text { (FP) }\end{array}$ & All & Multiple \\
\hline Guthrie (2001) & $\begin{array}{l}\text { Companies in New } \\
\text { Zealand }\end{array}$ & 164 & -.05 & .13 & Total & $\begin{array}{l}\text { Productivity } \\
\text { (WP) }\end{array}$ & All & Multiple \\
\hline $\begin{array}{l}\text { Guthrie \& Datta } \\
\text { (2008) }\end{array}$ & $\begin{array}{l}\text { U.S. publicly traded } \\
\text { firms } \\
\text { (Compustat) }\end{array}$ & 122 & -.29 & .26 & Executive & ROA (FP) & All & Manufacturing \\
\hline \multirow[t]{4}{*}{$\begin{array}{l}\text { Guthrie et al. } \\
\text { (2010) }\end{array}$} & U.S. firms & 124 & .10 & .12 & Voluntary & $\begin{array}{l}\text { Sales growth } \\
\text { (WP) }\end{array}$ & All & Manufacturing \\
\hline & & 124 & -.07 & .12 & Voluntary & ROA (FP) & All & Manufacturing \\
\hline & & 124 & .07 & .06 & Involuntary & $\begin{array}{l}\text { Sales growth } \\
\text { (WP) }\end{array}$ & All & Manufacturing \\
\hline & & 124 & -.10 & .06 & Involuntary & ROA (FP) & All & Manufacturing \\
\hline $\begin{array}{l}\text { Guthrie et al. } \\
\text { (2009) }\end{array}$ & $\begin{array}{l}\text { Companies from } \\
\text { Irish Top } 1,000 \\
\text { companies }\end{array}$ & 149 & .05 & .14 & Total & $\begin{array}{l}\text { Productivity } \\
\text { (WP) }\end{array}$ & All & Multiple \\
\hline
\end{tabular}


Appendix A (continued)

\begin{tabular}{|c|c|c|c|c|c|c|c|c|}
\hline Article $^{a}$ & Sample & $\begin{array}{c}\text { Sample } \\
\text { size }\end{array}$ & Correlation & $\begin{array}{l}\text { Turnover } \\
\text { rates }\end{array}$ & $\begin{array}{l}\text { Turnover } \\
\text { type }^{b}\end{array}$ & $\begin{array}{l}\text { Performance } \\
\text { dimensions }\end{array}$ & $\begin{array}{l}\text { Employment } \\
\text { system }\end{array}$ & Industry \\
\hline \multirow[t]{2}{*}{ Hansson (2007) } & \multirow[t]{2}{*}{$\begin{array}{l}\text { European } \\
\text { companies }\end{array}$} & 4,078 & -.01 & .10 & Total & $\begin{array}{l}\text { Prior profit } \\
\text { (FP) }\end{array}$ & All & Multiple \\
\hline & & 4,313 & .00 & .10 & Total & $\begin{array}{l}\text { Top } 10 \% \\
\text { profitability } \\
\text { (FP) }\end{array}$ & All & Multiple \\
\hline $\begin{array}{l}\text { Hatch \& Dyer } \\
\text { (2004) }\end{array}$ & $\begin{array}{l}\text { Semi-conductor } \\
\text { facilities }\end{array}$ & 702 & -.05 & .21 & Total & $\begin{array}{l}\text { Defect density } \\
\text { (Q) }\end{array}$ & Primary & Manufacturing \\
\hline $\begin{array}{l}\text { Hausknecht } \\
\text { et al. (2009) }\end{array}$ & $\begin{array}{l}\text { A large leisure and } \\
\text { hospitality } \\
\text { organization }\end{array}$ & 75 & -.31 & .26 & Voluntary & $\begin{array}{l}\text { Customer } \\
\text { perception } \\
\text { of service } \\
\text { quality } \\
\text { (CS) }\end{array}$ & Secondary & Service \\
\hline \multirow[t]{3}{*}{$\begin{array}{l}\text { Holman et al. } \\
\text { (2009) }\end{array}$} & \multirow[t]{3}{*}{$\begin{array}{l}\text { Call centers in } 17 \\
\text { countries }\end{array}$} & 2,359 & -.01 & .64 & Total & $\begin{array}{l}\text { Labor costs } \\
\text { (FP) }\end{array}$ & All & Service \\
\hline & & 2,359 & .10 & .23 & Total & $\begin{array}{l}\text { Sales change } \\
\text { (WP) }\end{array}$ & All & Service \\
\hline & & 2,359 & -.04 & .05 & Total & $\begin{array}{l}\text { Call } \\
\text { abandonment } \\
\text { (WP) }\end{array}$ & All & Service \\
\hline \multirow[t]{3}{*}{ Huselid (1995) } & \multirow[t]{3}{*}{$\begin{array}{l}\text { Publicly held U.S. } \\
\text { firms }\end{array}$} & 816 & -.24 & .18 & Total & $\begin{array}{l}\text { Productivity } \\
\text { (WP) }\end{array}$ & All & Multiple \\
\hline & & 816 & -.10 & .18 & Total & $\begin{array}{l}\text { Tobin's q } \\
\text { (FP) }\end{array}$ & All & Multiple \\
\hline & & 816 & -.03 & .18 & Total & GRATE (FP) & All & Multiple \\
\hline \multirow[t]{3}{*}{ Keck (1997) } & Cement stable & 438 & .03 & .07 & Total & $\begin{array}{l}\text { 2-year ROA } \\
\text { growth (FP) }\end{array}$ & Executives & Manufacturing \\
\hline & Cement turbulent & 280 & -.04 & .11 & Total & $\begin{array}{l}\text { 2-year ROA } \\
\text { growth (FP) }\end{array}$ & Executives & Manufacturing \\
\hline & Minicomputer & 18 & -.50 & .27 & Total & $\begin{array}{l}\text { 2-year ROA } \\
\text { growth (FP) }\end{array}$ & Executives & Manufacturing \\
\hline $\begin{array}{l}\text { Kim \& Park } \\
\quad(2011)\end{array}$ & $\begin{array}{l}\text { Korean start-up } \\
\text { firms }\end{array}$ & 515 & .15 & .50 & Total & $\begin{array}{l}\text { Change in } \\
\text { ROA (FP) }\end{array}$ & All & Multiple \\
\hline \multirow[t]{2}{*}{$\begin{array}{l}\text { Koslowsky \& } \\
\text { Locke (1989) }\end{array}$} & $\begin{array}{l}\text { Large retail outlets } \\
\text { in a national } \\
\text { chain }\end{array}$ & 290 & -.02 & .80 & Total & Profit (FP) & Secondary & Service \\
\hline & & 290 & .04 & .80 & Total & $\begin{array}{l}\text { Sales per } \\
\text { square foot } \\
\text { (WP) }\end{array}$ & Secondary & Service \\
\hline \multirow[t]{9}{*}{ Koys (2001) } & \multirow[t]{9}{*}{$\begin{array}{l}\text { Regional } \\
\text { restaurants }\end{array}$} & 28 & .00 & 1.05 & Total & $\begin{array}{l}\text { Profit/sales } \\
\text { (FP) }\end{array}$ & All & Restaurant \\
\hline & & 28 & -.20 & 1.05 & Total & $\begin{array}{l}\text { Profit/sales } \\
\mathrm{t}+1(\mathrm{FP})\end{array}$ & All & Restaurant \\
\hline & & 28 & -.28 & .86 & Total $(\mathrm{t}+1)$ & $\begin{array}{l}\text { Profit/Sales } \\
\mathrm{t}+1(\mathrm{FP})\end{array}$ & All & Restaurant \\
\hline & & 28 & .10 & 1.05 & Total & Profit (FP) & All & Restaurant \\
\hline & & 28 & -.22 & 1.05 & Total & $\begin{array}{l}\text { Profit } t+1 \\
\quad(F P)\end{array}$ & All & Restaurant \\
\hline & & 28 & -.24 & .86 & Total $(\mathrm{t}+1)$ & $\begin{array}{l}\text { Profit } t+1 \\
\quad(F P)\end{array}$ & All & Restaurant \\
\hline & & 24 & -.10 & 1.05 & Total & $\mathrm{CS}$ & All & Restaurant \\
\hline & & 24 & -.32 & 1.05 & Total & $\begin{array}{l}\mathrm{CS} \mathrm{t}+1 \\
(\mathrm{CS})\end{array}$ & All & Restaurant \\
\hline & & 24 & .08 & 86 & Total $(\mathrm{t}+1)$ & $\begin{array}{l}\mathrm{CSt}+1 \\
(\mathrm{CS})\end{array}$ & All & Restaurant \\
\hline $\begin{array}{l}\text { Krishnan et al. } \\
\text { (2007) }\end{array}$ & U.S. firms & 174 & -.41 & .04 & Total & $\begin{array}{l}\text { Return on } \\
\text { sales (FP) }\end{array}$ & All & Multiple \\
\hline $\begin{array}{l}\text { Leveck \& Jones } \\
\quad \text { (1996) }\end{array}$ & $\begin{array}{l}\text { Inpatient nursing } \\
\text { units in hospitals }\end{array}$ & 63 & -.24 & .33 & Total & $\begin{array}{r}\text { Quality of } \\
\text { care }(\mathrm{Q})\end{array}$ & Primary & Hospital \\
\hline
\end{tabular}


Appendix A (continued)

\begin{tabular}{|c|c|c|c|c|c|c|c|c|}
\hline Article $^{a}$ & Sample & $\begin{array}{c}\text { Sample } \\
\text { size }\end{array}$ & Correlation & $\begin{array}{l}\text { Turnover } \\
\text { rates }\end{array}$ & $\begin{array}{l}\text { Turnover } \\
\text { type }^{b}\end{array}$ & $\begin{array}{l}\text { Performance } \\
\text { dimensions }\end{array}$ & $\begin{array}{l}\text { Employment } \\
\text { system }\end{array}$ & Industry \\
\hline \multirow[t]{9}{*}{ Lynn (2002) } & $\begin{array}{l}\text { Casual-dining } \\
\text { restaurants in the } \\
\text { United States }\end{array}$ & 59 & -.30 & 1.12 & Total & $\begin{array}{l}\text { Annual sales } \\
\text { (WP) }\end{array}$ & All & Restaurant \\
\hline & & 59 & -.34 & 1.12 & Total & $\begin{array}{l}\text { Service } \\
\quad \text { quality } \\
\text { (CS) }\end{array}$ & All & Restaurant \\
\hline & & 59 & -.14 & 1.12 & Total & $\begin{array}{l}\text { Charge tip } \\
\text { percent } \\
\text { (WP) }\end{array}$ & All & Restaurant \\
\hline & $\begin{array}{l}\text { Casual-dining } \\
\text { restaurants in the } \\
\text { United States } \\
\text { (low-volume) }\end{array}$ & 29 & -.01 & & Total & $\begin{array}{l}\text { Annual sales } \\
\text { (WP) }\end{array}$ & All & Restaurant \\
\hline & & 29 & -.04 & & Total & $\begin{array}{l}\text { Service } \\
\quad \text { quality } \\
\text { (CS) }\end{array}$ & All & Restaurant \\
\hline & & 29 & -.36 & & Total & $\begin{array}{l}\text { Charge tip } \\
\text { percent } \\
\text { (WP) }\end{array}$ & All & Restaurant \\
\hline & $\begin{array}{l}\text { Casual-dining } \\
\text { restaurants in the } \\
\text { United States } \\
\text { (high-volume) }\end{array}$ & 30 & -.40 & & Total & $\begin{array}{l}\text { Annual sales } \\
\text { (WP) }\end{array}$ & All & Restaurant \\
\hline & & 30 & -.44 & & Total & $\begin{array}{l}\text { Service } \\
\text { quality } \\
\text { (CS) }\end{array}$ & All & Restaurant \\
\hline & & 30 & .11 & & Total & $\begin{array}{l}\text { Charge tip } \\
\text { percent } \\
\text { (WP) }\end{array}$ & All & Restaurant \\
\hline \multirow[t]{3}{*}{$\begin{array}{l}\text { MacKenzie } \\
\text { et al. (2011) }\end{array}$} & $\begin{array}{l}\text { Limited-menu } \\
\text { restaurants in the } \\
\text { United States }\end{array}$ & 150 & -.35 & 1.99 & Total & $\begin{array}{l}\text { Work group } \\
\text { task } \\
\text { performance } \\
\text { (EWA) }\end{array}$ & All & Restaurant \\
\hline & & 150 & -.23 & 1.99 & Total & Sales (WP) & All & Restaurant \\
\hline & & 150 & -.20 & 1.99 & Total & Profit (FP) & All & Restaurant \\
\hline \multirow[t]{10}{*}{$\begin{array}{l}\text { McElroy et al. } \\
\text { (2001) }\end{array}$} & $\begin{array}{l}\text { National financial } \\
\text { service company } \\
\text { units }\end{array}$ & 31 & -.47 & .34 & Voluntary & $\begin{array}{l}\text { Profitability } \\
\text { (FP) }\end{array}$ & All & Banking \\
\hline & & 31 & -.43 & .34 & Voluntary & $\begin{array}{l}\text { Productivity } \\
\text { (WP) }\end{array}$ & All & Banking \\
\hline & & 31 & -.46 & .34 & Voluntary & $\begin{array}{l}\text { Customer } \\
\text { satisfaction } \\
\text { (CS) }\end{array}$ & All & Banking \\
\hline & & 31 & -.49 & .34 & Voluntary & $\begin{array}{l}\text { Profitability } \\
t+1 \text { (FP) }\end{array}$ & All & Banking \\
\hline & & 31 & -.56 & .34 & Voluntary & $\begin{array}{l}\text { Productivity } \\
\mathrm{t}+1 \text { (WP) }\end{array}$ & All & Banking \\
\hline & & 31 & -.58 & .34 & Voluntary & $\begin{array}{c}\text { Cost per loan } \\
t+1(\mathrm{FP})\end{array}$ & All & Banking \\
\hline & & 31 & -.47 & .05 & Involuntary & $\begin{array}{l}\text { Profitability } \\
\text { (FP) }\end{array}$ & All & Banking \\
\hline & & 31 & -.35 & .05 & Involuntary & $\begin{array}{l}\text { Productivity } \\
\text { (WP) }\end{array}$ & All & Banking \\
\hline & & 31 & -.65 & .05 & Involuntary & $\begin{array}{l}\text { Customer } \\
\text { satisfaction } \\
\text { (CS) }\end{array}$ & All & Banking \\
\hline & & 31 & -.36 & .05 & Involuntary & $\begin{array}{l}\text { Profitability } \\
\text { t }+1 \text { (FP) }\end{array}$ & All & Banking \\
\hline
\end{tabular}

(Appendices continue) 
Appendix A (continued)

\begin{tabular}{|c|c|c|c|c|c|c|c|c|}
\hline Article $^{a}$ & Sample & $\begin{array}{l}\text { Sample } \\
\text { size }\end{array}$ & Correlation & $\begin{array}{l}\text { Turnover } \\
\text { rates }\end{array}$ & $\begin{array}{c}\text { Turnover } \\
\text { type }^{\mathrm{b}}\end{array}$ & $\begin{array}{l}\text { Performance } \\
\text { dimensions }\end{array}$ & $\begin{array}{l}\text { Employment } \\
\text { system }\end{array}$ & Industry \\
\hline & & 31 & -.42 & .05 & Involuntary & $\begin{array}{l}\text { Productivity t } \\
\quad+1 \text { (WP) }\end{array}$ & All & Banking \\
\hline & & 31 & -.52 & .05 & Involuntary & $\begin{array}{c}\text { Cost per loan } \\
\mathrm{t}+1(\mathrm{FP})\end{array}$ & All & Banking \\
\hline & & 31 & -.73 & .07 & Executive & $\begin{array}{l}\text { Profitability } \\
\text { (FP) }\end{array}$ & All & Banking \\
\hline & & 31 & -.31 & .07 & Executive & $\begin{array}{l}\text { Productivity } \\
\text { (WP) }\end{array}$ & All & Banking \\
\hline & & 31 & -.75 & .07 & Executive & $\begin{array}{l}\text { Customer } \\
\text { satisfaction } \\
\text { (CS) }\end{array}$ & All & Banking \\
\hline & & 31 & -.80 & .07 & Executive & $\begin{array}{l}\text { Profitability } \\
\text { t }+1 \text { (FP) }\end{array}$ & All & Banking \\
\hline & & 31 & -.45 & .07 & Executive & $\begin{array}{l}\text { Productivity } \\
t+1 \text { (WP) }\end{array}$ & All & Banking \\
\hline & & 31 & -.71 & .07 & Executive & $\begin{array}{c}\text { Cost per loan } \\
t+1(\mathrm{FP})\end{array}$ & All & Banking \\
\hline \multirow{8}{*}{$\begin{array}{l}\text { Meier \& } \\
\text { Hicklin } \\
\text { (2007) }\end{array}$} & Schools in Texas & 4,315 & -.04 & .14 & Total & TAAS (WP) & Primary & Education \\
\hline & & 4,315 & -.07 & .14 & Total & $\begin{array}{l}\text { SAT/ACT } \\
\text { (WP) }\end{array}$ & Primary & Education \\
\hline & & 3,844 & -.09 & .14 & Total (t-1) & TAAS (WP) & Primary & Education \\
\hline & & 3,844 & -.11 & .14 & Total (t-1) & $\begin{array}{l}\text { SAT/ACT } \\
\text { (WP) }\end{array}$ & Primary & Education \\
\hline & & 3,369 & -.16 & .14 & Total $(\mathrm{t}-2)$ & TAAS (WP) & Primary & Education \\
\hline & & 3,369 & -.16 & .14 & Total (t-2) & $\begin{array}{l}\text { SAT/ACT } \\
\text { (WP) }\end{array}$ & Primary & Education \\
\hline & & 2,892 & -.24 & .58 & Total (4yr) & TAAS (WP) & Primary & Education \\
\hline & & 2,892 & -.19 & .58 & Total (4yr) & $\begin{array}{l}\text { SAT/ACT } \\
\text { (WP) }\end{array}$ & Primary & Education \\
\hline \multirow{3}{*}{$\begin{array}{l}\text { Meier et al. } \\
\quad(2006)\end{array}$} & Schools in Texas & 3,117 & -.12 & .17 & Total & TAAS (WP) & Primary & Education \\
\hline & & 2,610 & -.13 & .17 & Total & $\begin{array}{l}\text { SAT/ACT } \\
\text { (WP) }\end{array}$ & Primary & Education \\
\hline & & 2,897 & -.03 & .17 & Total & $\begin{array}{l}\text { SAT dropouts } \\
\text { (Q) }\end{array}$ & Primary & Education \\
\hline \multirow{5}{*}{$\begin{array}{l}\text { Messersmith \& } \\
\text { Guthrie } \\
\text { (2010) }\end{array}$} & $\begin{array}{l}\text { U.S. companies } \\
\text { from NETS }\end{array}$ & 215 & -.08 & .09 & Voluntary & $\begin{array}{l}\text { Sales growth } \\
\text { (WP) }\end{array}$ & All & Multiple \\
\hline & & 215 & -.21 & .09 & Voluntary & $\begin{array}{l}\text { Innovation } \\
\text { (WP) }\end{array}$ & All & Multiple \\
\hline & & 215 & -.17 & .09 & Voluntary & $\begin{array}{l}\text { Product } \\
\text { innovation } \\
\text { (WP) }\end{array}$ & All & Multiple \\
\hline & & 215 & -.13 & .09 & Voluntary & $\begin{array}{l}\text { Process } \\
\text { innovation } \\
\text { (WP) }\end{array}$ & All & Multiple \\
\hline & & 215 & -.18 & .09 & Voluntary & $\begin{array}{l}\text { Organizational } \\
\text { innovation } \\
\text { (WP) }\end{array}$ & All & Multiple \\
\hline $\begin{array}{l}\text { Messersmith } \\
\text { et al. (2010) }\end{array}$ & $\begin{array}{l}\text { Single industry } \\
\text { firms in the } \\
\text { United States }\end{array}$ & 554 & -.22 & .11 & Total & ROA (FP) & Executives & Multiple \\
\hline \multirow[t]{2}{*}{$\begin{array}{l}\text { Miah \& Bird } \\
\quad \text { (2007) }\end{array}$} & $\begin{array}{l}\text { South Asian local } \\
\text { companies }\end{array}$ & 182 & -.03 & & Total & $\begin{array}{l}\text { Firm } \\
\text { performance } \\
\text { (OP) }\end{array}$ & All & Multiple \\
\hline & $\begin{array}{l}\text { Japanese companies } \\
\text { in Japan }\end{array}$ & 139 & -.01 & & Total & $\begin{array}{l}\text { Firm } \\
\text { performance } \\
\text { (OP) }\end{array}$ & All & Multiple \\
\hline
\end{tabular}

(Appendices continue) 
Appendix A (continued)

\begin{tabular}{|c|c|c|c|c|c|c|c|c|}
\hline Article $^{a}$ & Sample & $\begin{array}{c}\text { Sample } \\
\text { size }\end{array}$ & Correlation & $\begin{array}{l}\text { Turnover } \\
\text { rates }\end{array}$ & $\begin{array}{l}\text { Turnover } \\
\text { type }^{\mathrm{b}}\end{array}$ & $\begin{array}{l}\text { Performance } \\
\text { dimensions }\end{array}$ & $\begin{array}{l}\text { Employment } \\
\text { system }\end{array}$ & Industry \\
\hline & $\begin{array}{l}\text { Japanese companies } \\
\text { in South Asia }\end{array}$ & 176 & -.05 & & Total & $\begin{array}{l}\text { Firm } \\
\text { performance } \\
\text { (OP) }\end{array}$ & All & Multiple \\
\hline \multirow[t]{2}{*}{$\begin{array}{l}\text { Mohr et al. } \\
\quad(2012)\end{array}$} & $\begin{array}{r}\text { Outpatient care at } \\
\text { medical centers }\end{array}$ & 114 & -.21 & .11 & Total & $\begin{array}{c}\text { Customer } \\
\text { service } \\
\text { (CS) }\end{array}$ & Primary & Hospital \\
\hline & & 114 & -.20 & .11 & Total & $\begin{array}{l}\text { Waiting times } \\
\text { (WP) }\end{array}$ & Primary & Hospital \\
\hline \multirow[t]{2}{*}{$\begin{array}{l}\text { Mueller \& Price } \\
\text { (1989) }\end{array}$} & $\begin{array}{l}\text { Work units in } \\
\text { hospitals }\end{array}$ & 115 & -.13 & .42 & Total & $\begin{array}{l}\text { Unit-level job } \\
\text { satisfaction } \\
\text { (EWA) }\end{array}$ & Primary & Hospital \\
\hline & & 115 & -.33 & .42 & Total & $\begin{array}{l}\text { Unit-level } \\
\text { behavioral } \\
\text { commitment } \\
\text { (EWA) }\end{array}$ & Primary & Hospital \\
\hline $\begin{array}{l}\text { Nixon et al. } \\
\text { (2004) }\end{array}$ & $\begin{array}{l}\text { U.S. firms from } \\
\text { Compustat and } \\
\text { CRSP }\end{array}$ & 364 & -.10 & & RIF & $\begin{array}{l}\text { Cumulative } \\
\text { abnormal } \\
\text { daily stock } \\
\text { returns (FP) }\end{array}$ & All & Multiple \\
\hline \multirow[t]{3}{*}{$\begin{array}{l}\text { Park \& Shaw } \\
\quad(2011)\end{array}$} & $\begin{array}{l}\text { Business units in a } \\
\text { large Korean } \\
\text { company }\end{array}$ & 75 & -.05 & .08 & Total & $\begin{array}{l}\text { Productivity } \\
\text { (WP) }\end{array}$ & All & Multiple \\
\hline & & 48 & -.13 & .08 & Total & ROA (FP) & All & Multiple \\
\hline & & 48 & -.29 & .08 & Total & ROE (FP) & All & Multiple \\
\hline \multirow{5}{*}{$\begin{array}{l}\text { Paul \& } \\
\text { Anantharaman } \\
\text { (2003) }\end{array}$} & $\begin{array}{l}\text { Indian software } \\
\text { companies }\end{array}$ & 34 & -.51 & .02 & Total & $\begin{array}{l}\text { Productivity } \\
\text { (WP) }\end{array}$ & Primary & IT \\
\hline & & 34 & -.46 & .02 & Total & Quality (Q) & Primary & IT \\
\hline & & 34 & -.38 & .02 & Total & $\begin{array}{l}\text { Speed of } \\
\text { delivery } \\
\text { (WP) }\end{array}$ & Primary & IT \\
\hline & & 34 & -.23 & .02 & Total & $\begin{array}{l}\text { Operating cost } \\
\text { (FP) }\end{array}$ & Primary & IT \\
\hline & & 34 & -.40 & .02 & Total & $\begin{array}{l}\text { Growth in } \\
\text { sales/net } \\
\text { profit/ROI } \\
\text { (FP) }\end{array}$ & Primary & IT \\
\hline \multirow[t]{2}{*}{$\begin{array}{l}\text { Peterson \& } \\
\text { Luthans } \\
(2006)\end{array}$} & $\begin{array}{l}\text { Fast-food franchises } \\
\text { in the United } \\
\text { States }\end{array}$ & 21 & -.47 & 2.12 & Total & $\begin{array}{l}\text { Gross profits } \\
\text { (FP) }\end{array}$ & All & Restaurant \\
\hline & & 21 & -.49 & 2.12 & Total & $\begin{array}{r}\text { Drive-through } \\
\text { times (WP) }\end{array}$ & All & Restaurant \\
\hline \multirow[t]{3}{*}{$\begin{array}{l}\text { Ployhart et al. } \\
\text { (2011) }\end{array}$} & $\begin{array}{l}\text { Quick service } \\
\text { franchises }\end{array}$ & 238 & -.07 & 1.43 & Total & $\begin{array}{l}\text { Sales per } \\
\text { labor hour } \\
\text { (WP) }\end{array}$ & All & Service \\
\hline & & 238 & -.50 & 1.43 & Total & $\begin{array}{l}\text { Receipts vs. } \\
\text { flow- } \\
\text { through } \\
\text { (FP) }\end{array}$ & All & Service \\
\hline & & 238 & -.45 & 1.43 & Total & $\begin{array}{l}\text { Unit service } \\
\text { performance } \\
\text { (CS) }\end{array}$ & All & Service \\
\hline \multirow[t]{4}{*}{$\begin{array}{l}\text { Ployhart et al. } \\
\text { (2009) }\end{array}$} & $\begin{array}{l}\text { Retail service } \\
\text { associates }\end{array}$ & 1,036 & .11 & .63 & Total & $\begin{array}{l}\text { Productivity } \\
\text { (WP) }\end{array}$ & All & Service \\
\hline & & 1,036 & .08 & .63 & Total & $\begin{array}{l}\text { Productivity } \\
t+1 \text { (WP) }\end{array}$ & All & Service \\
\hline & & 1,036 & .15 & .63 & Total & $\begin{array}{l}\text { Productivity } \\
t+2 \text { (WP) }\end{array}$ & All & Service \\
\hline & & 1,036 & .01 & .63 & Total & Profit (FP) & All & Service \\
\hline
\end{tabular}


Appendix A (continued)

\begin{tabular}{|c|c|c|c|c|c|c|c|c|}
\hline Article $^{a}$ & Sample & $\begin{array}{l}\text { Sample } \\
\text { size }\end{array}$ & Correlation & $\begin{array}{l}\text { Turnover } \\
\text { rates }\end{array}$ & $\begin{array}{l}\text { Turnover } \\
\text { type }^{b}\end{array}$ & $\begin{array}{l}\text { Performance } \\
\text { dimensions }\end{array}$ & $\begin{array}{l}\text { Employment } \\
\text { system }\end{array}$ & Industry \\
\hline & & 1,036 & .00 & .63 & Total & $\begin{array}{l}\text { Profit } t+1 \\
\quad(F P)\end{array}$ & All & Service \\
\hline & & 1,036 & .03 & .63 & Total & $\begin{array}{l}\text { Profit } t+2 \\
\quad(F P)\end{array}$ & All & Service \\
\hline & & 1,036 & -.05 & .63 & Total & Sales (WP) & All & Service \\
\hline & & 1,036 & -.06 & .63 & Total & $\begin{array}{l}\text { Sales } \mathrm{t}+1 \\
\quad(\mathrm{WP})\end{array}$ & All & Service \\
\hline & & 1,036 & -.06 & .63 & Total & $\begin{array}{l}\text { Sales } t+2 \\
\quad \text { (WP) }\end{array}$ & All & Service \\
\hline \multirow{2}{*}{$\begin{array}{l}\text { O. C. Richard } \\
\text { \& Johnson } \\
(2001)\end{array}$} & $\begin{array}{l}\text { Banks in California } \\
\text { and Kentucky }\end{array}$ & 73 & -.19 & .16 & Total & $\begin{array}{l}\text { Net income } \\
\text { (FP) }\end{array}$ & All & Banking \\
\hline & & 73 & .01 & .16 & Total & ROE (FP) & All & Banking \\
\hline $\begin{array}{l}\text { Richardson \& } \\
\text { Vandenberg } \\
\text { (2005) }\end{array}$ & $\begin{array}{l}\text { Work units in U.S. } \\
\text { organizations }\end{array}$ & 167 & -.23 & .14 & Voluntary & $\begin{array}{l}\text { Absenteeism } \\
\text { (WP) }\end{array}$ & All & Multiple \\
\hline \multirow[t]{6}{*}{$\begin{array}{l}\text { Riordan et al. } \\
\text { (2005) }\end{array}$} & $\begin{array}{l}\text { Insurance } \\
\text { companies }\end{array}$ & 92 & -.23 & .17 & Total & ROA (FP) & All & Banking \\
\hline & & 92 & .09 & .17 & Total & $\begin{array}{l}\text { Gain from net } \\
\text { premiums } \\
\text { (FP) }\end{array}$ & All & Banking \\
\hline & & 92 & .08 & .17 & Total & $\begin{array}{l}\text { Return on } \\
\text { surplus } \\
\text { (FP) }\end{array}$ & All & Banking \\
\hline & & 92 & -.03 & .17 & Total & $\begin{array}{l}\log \mathrm{ROA} \\
\text { (FP) }\end{array}$ & All & Banking \\
\hline & & 92 & .09 & .17 & Total & $\begin{array}{l}\text { Log gain from } \\
\text { net } \\
\text { premiums } \\
\text { (FP) }\end{array}$ & All & Banking \\
\hline & & 92 & -.09 & .17 & Total & $\begin{array}{l}\text { Log return on } \\
\text { surplus } \\
\text { (FP) }\end{array}$ & All & Banking \\
\hline \multirow[t]{10}{*}{$\begin{array}{l}\text { Ryan et al. } \\
\text { (1996) }\end{array}$} & $\begin{array}{l}\text { Branches of a large } \\
\text { financial service }\end{array}$ & 131 & -.13 & .08 & Total (92) & $\begin{array}{l}\text { Customer } \\
\text { satisfaction } \\
\text { (CS) }\end{array}$ & All & Banking \\
\hline & & 131 & .15 & .08 & Total (92) & Profit (FP) & All & Banking \\
\hline & & 131 & -.03 & .08 & Total (92) & $\begin{array}{l}\text { Market share } \\
\text { (OP) }\end{array}$ & All & Banking \\
\hline & & 131 & .12 & .08 & Total (92) & Volume (WP) & All & Banking \\
\hline & & 131 & -.13 & .08 & Total (92) & $\begin{array}{l}\text { Operating } \\
\text { costs (FP) }\end{array}$ & All & Banking \\
\hline & & 131 & .01 & .08 & Total (92) & $\begin{array}{l}\text { Probability of } \\
\text { payment } \\
\text { under } 85 \% \\
\text { (FP) }\end{array}$ & All & Banking \\
\hline & & 131 & -.12 & .08 & Total (92) & $\begin{array}{l}\text { Credit losses } \\
\text { (FP) }\end{array}$ & All & Banking \\
\hline & & 131 & -.18 & .08 & Total (92) & $\begin{array}{l}\text { Repossession } \\
\text { ratio (FP) }\end{array}$ & All & Banking \\
\hline & & 131 & -.18 & .08 & Total (92) & $\begin{array}{l}30 \text { day } \\
\text { delinquency } \\
\text { (FP) }\end{array}$ & All & Banking \\
\hline & & 131 & -.20 & .08 & Total (92) & $\begin{array}{l}60 \text { day } \\
\text { delinquency } \\
\text { (FP) }\end{array}$ & All & Banking \\
\hline
\end{tabular}

(Appendices continue) 
Appendix A (continued)

\begin{tabular}{|c|c|c|c|c|c|c|c|c|}
\hline Article $^{a}$ & Sample & $\underset{\text { size }}{\text { Sample }}$ & Correlation & $\begin{array}{l}\text { Turnover } \\
\text { rates }\end{array}$ & $\begin{array}{c}\text { Turnover } \\
\text { type }^{\mathrm{b}}\end{array}$ & $\begin{array}{l}\text { Performance } \\
\text { dimensions }\end{array}$ & $\begin{array}{l}\text { Employment } \\
\text { system }\end{array}$ & Industry \\
\hline & & 131 & -.45 & .06 & Total (93) & $\begin{array}{l}\text { Customer } \\
\text { satisfaction } \\
\text { (CS) }\end{array}$ & All & Banking \\
\hline & & 131 & .10 & .06 & Total (93) & Profit (FP) & All & Banking \\
\hline & & 131 & -.25 & .06 & Total (93) & $\begin{array}{l}\text { Market share } \\
\text { (OP) }\end{array}$ & All & Banking \\
\hline & & 131 & .02 & .06 & Total (93) & Volume (WP) & All & Banking \\
\hline & & 131 & -.06 & .06 & Total (93) & $\begin{array}{l}\text { Operating } \\
\text { costs (FP) }\end{array}$ & All & Banking \\
\hline & & 131 & -.14 & .06 & Total (93) & $\begin{array}{l}\text { Probability of } \\
\text { payment } \\
\text { under } 85 \% \\
\text { (FP) }\end{array}$ & All & Banking \\
\hline & & 131 & -.11 & .06 & Total (93) & $\begin{array}{l}\text { Credit losses } \\
\text { (FP) }\end{array}$ & All & Banking \\
\hline & & 131 & -.15 & .06 & Total (93) & $\begin{array}{l}\text { Repossession } \\
\text { ratio (FP) }\end{array}$ & All & Banking \\
\hline & & 131 & -.27 & .06 & Total (93) & $\begin{array}{l}\text { 30-day } \\
\text { delinquency } \\
\text { (FP) }\end{array}$ & All & Banking \\
\hline & & 131 & -.23 & .06 & Total (93) & $\begin{array}{l}\text { 60-day } \\
\text { delinquency } \\
\text { (FP) }\end{array}$ & All & Banking \\
\hline $\begin{array}{l}\text { Sacco \& } \\
\text { Schmitt } \\
(2005)\end{array}$ & $\begin{array}{l}\text { U.S. quick-service } \\
\text { restaurants }\end{array}$ & 2,373 & .00 & & Total & $\begin{array}{l}\text { Profitability } \\
\text { (FP) }\end{array}$ & Secondary & Restaurant \\
\hline \multirow[t]{5}{*}{$\begin{array}{l}\text { Sels et al. } \\
\text { (2006) }\end{array}$} & Belgian companies & 416 & -.19 & .10 & Voluntary & $\begin{array}{l}\text { Labor } \\
\text { productivity } \\
\text { (WP) }\end{array}$ & All & Multiple \\
\hline & & 416 & .04 & .10 & Voluntary & $\begin{array}{l}\text { Personnel } \\
\text { costs over } \\
\text { value added } \\
\text { (FP) }\end{array}$ & All & Multiple \\
\hline & & 416 & .06 & .10 & Voluntary & $\begin{array}{l}\text { Acid ratio test } \\
(\mathrm{FP})\end{array}$ & All & Multiple \\
\hline & & 416 & .06 & .10 & Voluntary & $\begin{array}{l}\text { Degree of } \\
\text { auto- } \\
\text { financing } \\
\text { (WP) }\end{array}$ & All & Multiple \\
\hline & & 416 & .08 & .10 & Voluntary & $\begin{array}{l}\text { Profitability } \\
\text { (FP) }\end{array}$ & All & Multiple \\
\hline \multirow[t]{4}{*}{$\begin{array}{l}\text { Shaw, Duffy, } \\
\text { et al. (2005) }\end{array}$} & $\begin{array}{l}\text { Stores of a } \\
\quad \text { restaurant chain }\end{array}$ & 38 & -.32 & .46 & Total & $\begin{array}{l}\text { Productivity } \\
\text { (WP) }\end{array}$ & All & Retail \\
\hline & & 38 & -.09 & .46 & Total & $\begin{array}{l}\text { In-role } \\
\text { performance } \\
\text { (EWA) }\end{array}$ & All & Retail \\
\hline & & 38 & -.25 & .46 & Total & $\begin{array}{l}\text { Change in } \\
\text { productivity } \\
\text { (WP) }\end{array}$ & All & Retail \\
\hline & & 38 & -.20 & .46 & Total & $\begin{array}{l}\text { Change in } \\
\text { sales (WP) }\end{array}$ & All & Retail \\
\hline \multirow[t]{2}{*}{$\begin{array}{r}\text { Shaw, Gupta, \& } \\
\text { Delery (2005) }\end{array}$} & $\begin{array}{l}\text { Concrete pipe } \\
\text { plants in the } \\
\text { United States }\end{array}$ & 120 & -.05 & .17 & Voluntary & $\begin{array}{l}\text { Labor hours } \\
\text { per ton } \\
\text { (WP) }\end{array}$ & Primary & Manufacturing \\
\hline & & 120 & -.02 & .17 & Voluntary & $\begin{array}{l}\text { Accident rate } \\
\quad(\mathrm{SR})\end{array}$ & Primary & Manufacturing \\
\hline
\end{tabular}

(Appendices continue) 
Appendix A (continued)

\begin{tabular}{|c|c|c|c|c|c|c|c|c|}
\hline Article $^{\mathrm{a}}$ & Sample & $\begin{array}{l}\text { Sample } \\
\text { size }\end{array}$ & Correlation & $\begin{array}{l}\text { Turnover } \\
\text { rates }\end{array}$ & $\begin{array}{l}\text { Turnover } \\
\text { type }^{\mathrm{b}}\end{array}$ & $\begin{array}{l}\text { Performance } \\
\text { dimensions }\end{array}$ & $\begin{array}{l}\text { Employment } \\
\text { system }\end{array}$ & Industry \\
\hline & $\begin{array}{l}\text { Trucking } \\
\text { companies }\end{array}$ & 325 & .06 & .41 & Voluntary & $\begin{array}{l}\text { Revenue per } \\
\text { driver (WP) }\end{array}$ & Primary & Trucking \\
\hline & & 347 & -.09 & .41 & Voluntary & $\begin{array}{l}\text { Accident } \\
\text { frequency } \\
\text { ratio }(\mathrm{SR})\end{array}$ & Primary & Trucking \\
\hline & & 356 & -.30 & .41 & Voluntary & $\begin{array}{l}\text { Out-of-service } \\
\text { percentage } \\
\text { (WP) }\end{array}$ & Primary & Trucking \\
\hline & & 325 & -.08 & .41 & Voluntary & $\begin{array}{l}\text { Operating } \\
\text { ratio (FP) }\end{array}$ & Primary & Trucking \\
\hline & & 325 & .12 & .41 & Voluntary & ROE (FP) & Primary & Trucking \\
\hline \multirow[t]{3}{*}{$\begin{array}{l}\text { Shaw et al. } \\
\text { (2012) }\end{array}$} & $\begin{array}{l}\text { Supermarkets in the } \\
\text { United States }\end{array}$ & 259 & -.03 & .18 & Voluntary & $\begin{array}{l}\text { Productivity } \\
\text { (WP) }\end{array}$ & Primary & Restaurant \\
\hline & & 259 & -.18 & .18 & Voluntary & $\begin{array}{l}\text { Accident rate } \\
\quad(\mathrm{SR})\end{array}$ & Primary & Restaurant \\
\hline & Korean companies & 365 & -.17 & .14 & Voluntary & $\begin{array}{l}\text { Productivity } \\
\text { (WP) }\end{array}$ & All & Multiple \\
\hline \multirow[t]{3}{*}{$\begin{array}{l}\text { Sheaffer et al. } \\
\text { (2009) }\end{array}$} & $\begin{array}{l}\text { Tel Aviv stock } \\
\text { exchange traded } \\
\text { firms }\end{array}$ & 196 & .05 & .49 & RIF & $\begin{array}{l}\text { Current ratio } \\
\text { (FP) }\end{array}$ & All & Multiple \\
\hline & & 196 & .15 & .49 & RIF & $\begin{array}{l}\text { Market cap } \\
\quad(\mathrm{FP})\end{array}$ & All & Multiple \\
\hline & & 196 & .12 & .49 & RIF & ROS (FP) & All & Multiple \\
\hline $\begin{array}{l}\text { Shen \& } \\
\text { Cannella } \\
\text { (2002) }\end{array}$ & $\begin{array}{l}\text { Large, publicly } \\
\text { traded U.S. } \\
\text { corporations }\end{array}$ & 228 & -.18 & .17 & Total & ROA (FP) & Executives & Multiple \\
\hline \multirow[t]{2}{*}{$\begin{array}{l}\text { Shevchuk et al. } \\
\text { (2007) }\end{array}$} & $\begin{array}{l}\text { Elementary schools } \\
\text { in a large U.S. } \\
\text { district }\end{array}$ & 593 & -.25 & .32 & Total & $\begin{array}{l}\text { Achievement } \\
\text { sores (WP) }\end{array}$ & Primary & Education \\
\hline & & 182 & -.36 & .23 & Total & $\begin{array}{l}\text { Achievement } \\
\text { sores 04-05 } \\
\text { (WP) }\end{array}$ & Primary & Education \\
\hline \multirow[t]{4}{*}{$\begin{array}{l}\text { Shortell et al. } \\
\text { (1994) }\end{array}$} & $\begin{array}{l}42 \text { ICUs at U.S. } \\
\text { nonfederal } \\
\text { hospitals }\end{array}$ & 42 & -.02 & .19 & Total & $\begin{array}{l}\text { Risk-adjusted } \\
\text { mortality } \\
\text { (WP) }\end{array}$ & Primary & Hospital \\
\hline & & 42 & -.20 & .19 & Total & $\begin{array}{l}\text { Risk-adjusted } \\
\text { length of } \\
\text { stay (WP) }\end{array}$ & Primary & Hospital \\
\hline & & 42 & -.32 & .19 & Total & $\begin{array}{c}\text { Quality of } \\
\text { care (Q) }\end{array}$ & Primary & Hospital \\
\hline & & 42 & -.41 & .19 & Total & $\begin{array}{l}\text { Ability to } \\
\text { meet family } \\
\text { needs (Q) }\end{array}$ & Primary & Hospital \\
\hline \multirow{2}{*}{$\begin{array}{l}\text { Siebert \& } \\
\text { Zubanov } \\
\text { (2009) }\end{array}$} & $\begin{array}{l}\text { U.K. clothing } \\
\text { retailers }\end{array}$ & 325 & -.24 & .05 & Total & $\begin{array}{l}\text { Productivity } \\
\text { (WP) }\end{array}$ & Primary & Retail \\
\hline & & 325 & -.02 & .08 & Total & $\begin{array}{l}\text { Productivity } \\
\text { (WP) }\end{array}$ & Secondary & Retail \\
\hline $\begin{array}{l}\text { Siebert \& } \\
\quad \text { Zubanov } \\
(2010)\end{array}$ & U.K. retailers & 245 & .17 & .15 & Total & $\begin{array}{l}\text { Productivity } \\
\text { (WP) }\end{array}$ & Primary & Retail \\
\hline \multirow[t]{3}{*}{$\begin{array}{l}\text { Simon et al. } \\
\text { (2012) }\end{array}$} & $\begin{array}{l}\text { Spanish fashion } \\
\text { retail group } \\
\text { establishments }\end{array}$ & 232 & .38 & .68 & Voluntary & $\begin{array}{l}\text { Sales per } \\
\quad \text { square } \\
\text { meter }(\mathrm{FP})\end{array}$ & All & Retail \\
\hline & & 232 & .19 & .68 & Voluntary & $\begin{array}{l}\text { Sales per hour } \\
\text { worked } \\
\text { (WF) }\end{array}$ & All & Retail \\
\hline & & 232 & .34 & 2.64 & Involuntary & $\begin{array}{l}\text { Sales per } \\
\quad \text { square } \\
\text { meter (FP) }\end{array}$ & All & Retail \\
\hline
\end{tabular}

(Appendices continue) 
Appendix A (continued)

\begin{tabular}{|c|c|c|c|c|c|c|c|c|}
\hline Article $^{\mathrm{a}}$ & Sample & $\begin{array}{c}\text { Sample } \\
\text { size }\end{array}$ & Correlation & $\begin{array}{l}\text { Turnover } \\
\text { rates }\end{array}$ & $\begin{array}{l}\text { Turnover } \\
\text { type }^{\mathrm{b}}\end{array}$ & $\begin{array}{l}\text { Performance } \\
\text { dimensions }\end{array}$ & $\begin{array}{l}\text { Employment } \\
\text { system }\end{array}$ & Industry \\
\hline & & 232 & .40 & 2.64 & Involuntary & $\begin{array}{l}\text { Sales per hour } \\
\text { worked } \\
\text { (WF) }\end{array}$ & All & Retail \\
\hline & & 232 & .40 & 3.32 & Total & $\begin{array}{l}\text { Sales per } \\
\text { square } \\
\text { meter (FP) }\end{array}$ & All & Retail \\
\hline & & 232 & .37 & 3.32 & Total & $\begin{array}{l}\text { Sales per hour } \\
\text { worked } \\
\text { (WF) }\end{array}$ & All & Retail \\
\hline \multirow[t]{2}{*}{$\begin{array}{l}\text { Sowinski et al. } \\
\text { (2008) }\end{array}$} & $\begin{array}{l}\text { Automotive service } \\
\text { stores }\end{array}$ & 129 & -.36 & .44 & Voluntary & $\begin{array}{l}\text { Customer } \\
\text { satisfaction } \\
\text { (CS) }\end{array}$ & All & Service \\
\hline & & 129 & -.14 & .44 & Voluntary & $\begin{array}{l}\text { Profitability } \\
\text { (FP) }\end{array}$ & All & Service \\
\hline \multirow[t]{2}{*}{ Stavrou (2005) } & $\begin{array}{l}\text { Organizations in } \\
\text { EU }\end{array}$ & 2,811 & .01 & .09 & Total & $\begin{array}{l}\text { Organizational } \\
\text { performance } \\
\text { (OP) }\end{array}$ & All & Multiple \\
\hline & & 2,811 & .01 & .09 & Total & $\begin{array}{l}\text { Absenteeism } \\
\text { (EWA) }\end{array}$ & All & Multiple \\
\hline \multirow[t]{8}{*}{$\begin{array}{l}\text { Subramony \& } \\
\text { Holtom } \\
\text { (2011a) }\end{array}$} & $\begin{array}{l}\text { Regional offices of } \\
\text { a temporary help } \\
\text { services firm }\end{array}$ & 46 & -.41 & .17 & Voluntary & $\begin{array}{l}\text { Customer } \\
\text { communication } \\
\text { (CS) }\end{array}$ & Primary & Service \\
\hline & & 46 & -.42 & .17 & Voluntary & $\begin{array}{l}\text { Customer } \\
\text { innovation } \\
\text { (CS) }\end{array}$ & Primary & Service \\
\hline & & 46 & -.43 & .17 & Voluntary & $\begin{array}{l}\text { Customer } \\
\text { satisfaction } \\
\text { (CS) }\end{array}$ & Primary & Service \\
\hline & & 46 & .05 & .17 & Voluntary & $\begin{array}{l}\text { Profit per } \\
\text { employee } \\
\text { (FP) }\end{array}$ & Primary & Service \\
\hline & & 46 & -.47 & .07 & Involuntary & $\begin{array}{l}\text { Customer } \\
\text { communication } \\
\text { (CS) }\end{array}$ & Primary & Service \\
\hline & & 46 & -.46 & .07 & Involuntary & $\begin{array}{l}\text { Customer } \\
\text { innovation } \\
\text { (CS) }\end{array}$ & Primary & Service \\
\hline & & 46 & -.43 & .07 & Involuntary & $\begin{array}{l}\text { Customer } \\
\text { satisfaction } \\
\text { (CS) }\end{array}$ & Primary & Service \\
\hline & & 46 & -.24 & .07 & Involuntary & $\begin{array}{l}\text { Profit per } \\
\text { employee } \\
\text { (FP) }\end{array}$ & Primary & Service \\
\hline \multirow[t]{5}{*}{$\begin{array}{l}\text { Subramony \& } \\
\text { Holtom } \\
(2011 b)\end{array}$} & $\begin{array}{l}\text { Regional offices of } \\
\text { a temporary help } \\
\text { services firm }\end{array}$ & 64 & -.23 & .31 & Voluntary & $\begin{array}{l}\text { Customer } \\
\text { orientation } \\
\text { (WP) }\end{array}$ & Primary & Service \\
\hline & & 64 & -.52 & .14 & RIF & $\begin{array}{l}\text { Customer } \\
\text { Orientation } \\
\text { (WP) }\end{array}$ & Primary & Service \\
\hline & & 64 & -.14 & .14 & RIF & $\begin{array}{l}\text { Customer } \\
\text { service } \\
\text { evaluations } \\
\text { (CS) }\end{array}$ & Primary & Service \\
\hline & & 64 & -.01 & .14 & RIF & $\begin{array}{l}\text { Service brand } \\
\text { attributes } \\
\text { (CS) }\end{array}$ & Primary & Service \\
\hline & & 64 & .48 & .14 & RIF & $\begin{array}{l}\text { Unit } \\
\text { profitability } \\
\text { (FP) }\end{array}$ & Primary & Service \\
\hline
\end{tabular}


Appendix A (continued)

\begin{tabular}{|c|c|c|c|c|c|c|c|c|}
\hline Article $^{a}$ & Sample & $\begin{array}{l}\text { Sample } \\
\text { size }\end{array}$ & Correlation & $\begin{array}{l}\text { Turnover } \\
\text { rates }\end{array}$ & $\begin{array}{l}\text { Turnover } \\
\text { type }^{\mathrm{b}}\end{array}$ & $\begin{array}{l}\text { Performance } \\
\text { dimensions }\end{array}$ & $\begin{array}{l}\text { Employment } \\
\text { system }\end{array}$ & Industry \\
\hline $\begin{array}{l}\text { Sun et al. } \\
\text { (2007) }\end{array}$ & Hotels in China & 81 & -.09 & .16 & Voluntary & $\begin{array}{l}\text { Productivity } \\
\text { (WP) }\end{array}$ & All & Service \\
\hline $\begin{array}{l}\text { Takeuchi et al. } \\
\text { (2009) }\end{array}$ & $\begin{array}{l}\text { Business units from } \\
\text { Japanese firms }\end{array}$ & 76 & -.126 & .04 & Voluntary & $\begin{array}{l}\text { Employee } \\
\text { performance } \\
\text { for the unit } \\
\text { (WP) }\end{array}$ & All & Multiple \\
\hline $\begin{array}{l}\text { Temkin-Greener } \\
\text { et al. (2009) }\end{array}$ & $\begin{array}{l}\text { Nursing homes in } \\
\text { New York }\end{array}$ & 160 & -.24 & .84 & Total & $\begin{array}{l}\text { Work } \\
\text { effectiveness } \\
\text { (OP) }\end{array}$ & Primary & Hospital \\
\hline \multirow[t]{8}{*}{$\begin{array}{l}\text { Ton \& } \\
\text { Huckman } \\
\text { (2008) }\end{array}$} & Borders stores & 11,325 & .00 & .04 & Total & $\begin{array}{c}\text { Customer } \\
\text { service } \\
\text { (CS) }\end{array}$ & $\begin{array}{l}\text { Primary } \\
\quad \text { (full-time) }\end{array}$ & Retail \\
\hline & & 12,717 & -.05 & .04 & Total & $\begin{array}{l}\text { Profit margin } \\
\text { (FP) }\end{array}$ & $\begin{array}{l}\text { Primary } \\
\quad \text { (full-time) }\end{array}$ & Retail \\
\hline & & 11,325 & -.01 & .07 & Total & $\begin{array}{c}\text { Customer } \\
\text { service } \\
\text { (CS) }\end{array}$ & $\begin{array}{l}\text { Secondary } \\
\text { (part- } \\
\text { time) }\end{array}$ & Retail \\
\hline & & 12,709 & -.07 & .07 & Total & $\begin{array}{l}\text { Profit margin } \\
\text { (FP) }\end{array}$ & $\begin{array}{l}\text { Secondary } \\
\text { (part- } \\
\text { time) }\end{array}$ & Retail \\
\hline & & 11,325 & .01 & .05 & Total & $\begin{array}{c}\text { Customer } \\
\text { service } \\
\text { (CS) }\end{array}$ & All & Retail \\
\hline & & 12,717 & -.06 & .05 & Total & $\begin{array}{l}\text { Profit margin } \\
\text { (FP) }\end{array}$ & All & Retail \\
\hline & & 11,325 & -.03 & .02 & Total & $\begin{array}{c}\text { Customer } \\
\text { service } \\
\text { (CS) }\end{array}$ & $\begin{array}{l}\text { Primary } \\
\quad \text { (manager) }\end{array}$ & Retail \\
\hline & & 12,717 & -.00 & .02 & Total & $\begin{array}{l}\text { Profit margin } \\
\text { (FP) }\end{array}$ & $\begin{array}{l}\text { Primary } \\
\quad \text { (manager) }\end{array}$ & Retail \\
\hline \multirow{2}{*}{$\begin{array}{l}\text { Tremblay \& } \\
\text { Chenevert } \\
\text { (2008) }\end{array}$} & $\begin{array}{l}\text { Canadian private } \\
\text { companies }\end{array}$ & 252 & -.04 & .09 & Voluntary & $\begin{array}{l}\text { Productivity } \\
\text { (WP) }\end{array}$ & All & Multiple \\
\hline & & 252 & -.16 & .09 & Voluntary & $\begin{array}{l}\text { Market } \\
\text { performance } \\
\text { (OP) }\end{array}$ & All & Multiple \\
\hline \multirow[t]{2}{*}{$\begin{array}{l}\text { Trevor \& } \\
\text { Nyberg } \\
(2008)\end{array}$} & $\begin{array}{l}\text { Companies applied } \\
\text { to employee- } \\
\text { friendly } \\
\text { companies in } \\
\text { Fortune }\end{array}$ & 267 & -.21 & & Voluntary & $\begin{array}{l}\text { Commitment } \\
\text { (EWA) }\end{array}$ & $\begin{array}{l}\text { Primary } \\
\quad \text { (full-time) }\end{array}$ & Multiple \\
\hline & & 267 & -.27 & & RIF & $\begin{array}{l}\text { Commitment } \\
\text { (EWA) }\end{array}$ & $\begin{array}{l}\text { Primary } \\
\quad \text { (full-time) }\end{array}$ & Multiple \\
\hline $\begin{array}{l}\text { Van der Vegt } \\
\text { et al. (2010) }\end{array}$ & $\begin{array}{l}\text { Production teams in } \\
\text { a Volvo plant }\end{array}$ & 47 & -.55 & .40 & Voluntary & Quality (Q) & Primary & Manufacturing \\
\hline \multirow[t]{4}{*}{$\begin{array}{l}\text { Van Iddekinge } \\
\text { et al. (2009) }\end{array}$} & $\begin{array}{l}\text { A large fast-food } \\
\text { organization }\end{array}$ & 861 & -.12 & .13 & Total & $\begin{array}{c}\text { Customer } \\
\text { service } \\
\text { (CS) }\end{array}$ & Primary & Restaurant \\
\hline & & 861 & -.12 & .13 & Total & $\begin{array}{l}\text { Customer } \\
\text { service } \\
\mathrm{t}+1(\mathrm{CS})\end{array}$ & Primary & Restaurant \\
\hline & & 861 & -.05 & .13 & Total & $\begin{array}{l}\text { Customer } \\
\text { service } \\
\mathrm{t}+2(\mathrm{CS})\end{array}$ & Primary & Restaurant \\
\hline & & 861 & -.11 & .13 & Total & $\begin{array}{l}\text { Customer } \\
\text { service } \\
\mathrm{t}+3(\mathrm{CS})\end{array}$ & Primary & Restaurant \\
\hline
\end{tabular}


Appendix A (continued)

\begin{tabular}{|c|c|c|c|c|c|c|c|c|}
\hline Article $^{\mathrm{a}}$ & Sample & $\begin{array}{l}\text { Sample } \\
\text { size }\end{array}$ & Correlation & $\begin{array}{l}\text { Turnover } \\
\text { rates }\end{array}$ & $\begin{array}{l}\text { Turnover } \\
\text { type }^{b}\end{array}$ & $\begin{array}{l}\text { Performance } \\
\text { dimensions }\end{array}$ & $\begin{array}{l}\text { Employment } \\
\text { system }\end{array}$ & Industry \\
\hline & & 861 & -.01 & .13 & Total & $\begin{array}{l}\text { Customer } \\
\text { service } \\
\mathrm{t}+4(\mathrm{CS})\end{array}$ & Primary & Restaurant \\
\hline & & 861 & -.09 & .13 & Total & $\begin{array}{l}\text { Customer } \\
\text { service } \\
\mathrm{t}+5(\mathrm{CS})\end{array}$ & Primary & Restaurant \\
\hline & & 861 & -.10 & .13 & Total & Profit & Primary & Restaurant \\
\hline & & 861 & -.06 & .13 & Total & $\begin{array}{l}\text { Profit } t+1 \\
\text { (FP) }\end{array}$ & Primary & Restaurant \\
\hline & & 861 & -.10 & .13 & Total & $\begin{array}{l}\text { Profit } t+2 \\
\text { (FP) }\end{array}$ & Primary & Restaurant \\
\hline & & 861 & -.09 & .13 & Total & $\begin{array}{l}\text { Profit } t+3 \\
\text { (FP) }\end{array}$ & Primary & Restaurant \\
\hline & & 861 & -.11 & .13 & Total & $\begin{array}{l}\text { Profit } t+4 \\
\text { (FP) }\end{array}$ & Primary & Restaurant \\
\hline & & 861 & -.13 & .13 & Total & $\begin{array}{l}\text { Profit } t+5 \\
\text { (FP) }\end{array}$ & Primary & Restaurant \\
\hline & & 861 & -.13 & .12 & Total $(\mathrm{t}+1)$ & $\begin{array}{l}\text { Customer } \\
\text { service } \\
\mathrm{t}+1(\mathrm{CS})\end{array}$ & Primary & Restaurant \\
\hline & & 861 & -.13 & .12 & Total $(\mathrm{t}+1)$ & $\begin{array}{l}\text { Customer } \\
\text { service } \\
\mathrm{t}+2(\mathrm{CS})\end{array}$ & Primary & Restaurant \\
\hline & & 861 & -.21 & .12 & Total $(\mathrm{t}+1)$ & $\begin{array}{l}\text { Customer } \\
\text { service } \\
\mathrm{t}+3(\mathrm{CS})\end{array}$ & Primary & Restaurant \\
\hline & & 861 & -.09 & .12 & Total $(\mathrm{t}+1)$ & $\begin{array}{l}\text { Customer } \\
\text { service } \\
\mathrm{t}+4(\mathrm{CS})\end{array}$ & Primary & Restaurant \\
\hline & & 861 & -.13 & .12 & Total $(\mathrm{t}+1)$ & $\begin{array}{l}\text { Customer } \\
\text { service } \\
\mathrm{t}+5(\mathrm{CS})\end{array}$ & Primary & Restaurant \\
\hline & & 861 & -.08 & .12 & Total $(\mathrm{t}+1)$ & $\begin{array}{l}\text { Profit } t+1 \\
\quad(F P)\end{array}$ & Primary & Restaurant \\
\hline & & 861 & -.16 & .12 & Total $(\mathrm{t}+1)$ & $\begin{array}{l}\text { Profit } t+2 \\
\text { (FP) }\end{array}$ & Primary & Restaurant \\
\hline & & 861 & -.14 & .12 & Total $(\mathrm{t}+1)$ & $\begin{array}{l}\text { Profit } t+3 \\
\text { (FP) }\end{array}$ & Primary & Restaurant \\
\hline & & 861 & -.10 & .12 & Total $(\mathrm{t}+1)$ & $\begin{array}{l}\text { Profit } t+4 \\
\text { (FP) }\end{array}$ & Primary & Restaurant \\
\hline & & 861 & -.20 & .12 & Total $(\mathrm{t}+1)$ & $\begin{array}{l}\text { Profit } t+5 \\
\text { (FP) }\end{array}$ & Primary & Restaurant \\
\hline & & 861 & -.19 & .12 & Total $(\mathrm{t}+2)$ & $\begin{array}{l}\text { Customer } \\
\text { service } \\
t+2(\mathrm{CS})\end{array}$ & Primary & Restaurant \\
\hline & & 861 & -.20 & .12 & Total $(\mathrm{t}+2)$ & $\begin{array}{l}\text { Customer } \\
\text { service } \\
\mathrm{t}+3(\mathrm{CS})\end{array}$ & Primary & Restaurant \\
\hline & & 861 & -.11 & .12 & Total $(\mathrm{t}+2)$ & $\begin{array}{l}\text { Customer } \\
\text { service } \\
\mathrm{t}+4(\mathrm{CS})\end{array}$ & Primary & Restaurant \\
\hline & & 861 & -.13 & .12 & Total $(\mathrm{t}+2)$ & $\begin{array}{l}\text { Customer } \\
\text { service } \\
\mathrm{t}+5(\mathrm{CS})\end{array}$ & Primary & Restaurant \\
\hline & & 861 & -.17 & .12 & Total $(\mathrm{t}+2)$ & $\begin{array}{l}\text { Profit } t+2 \\
\quad(F P)\end{array}$ & Primary & Restaurant \\
\hline & & 861 & -.14 & .12 & Total $(\mathrm{t}+2)$ & $\begin{array}{l}\text { Profit } t+3 \\
\text { (FP) }\end{array}$ & Primary & Restaurant \\
\hline
\end{tabular}

(Appendices continue) 
Appendix A (continued)

\begin{tabular}{|c|c|c|c|c|c|c|c|c|}
\hline Article $^{a}$ & Sample & $\begin{array}{l}\text { Sample } \\
\text { size }\end{array}$ & Correlation & $\begin{array}{l}\text { Turnover } \\
\text { rates }\end{array}$ & $\begin{array}{c}\text { Turnover } \\
\text { type }^{\mathrm{b}}\end{array}$ & $\begin{array}{l}\text { Performance } \\
\text { dimensions }\end{array}$ & $\begin{array}{l}\text { Employment } \\
\text { system }\end{array}$ & Industry \\
\hline & & 861 & -.11 & .12 & Total $(\mathrm{t}+2)$ & $\begin{array}{l}\text { Profit } t+4 \\
\text { (FP) }\end{array}$ & Primary & Restaurant \\
\hline & & 861 & -.19 & .12 & Total $(\mathrm{t}+2)$ & $\begin{array}{l}\text { Profit } t+5 \\
\quad(F P)\end{array}$ & Primary & Restaurant \\
\hline & & 861 & -.23 & .14 & Total $(\mathrm{t}+3)$ & $\begin{array}{l}\text { Customer } \\
\text { service } \\
\mathrm{t}+3(\mathrm{CS})\end{array}$ & Primary & Restaurant \\
\hline & & 861 & -.12 & .14 & Total $(\mathrm{t}+3)$ & $\begin{array}{l}\text { Customer } \\
\text { service } \\
\mathrm{t}+4(\mathrm{CS})\end{array}$ & Primary & Restaurant \\
\hline & & 861 & -.13 & .14 & Total $(\mathrm{t}+3)$ & $\begin{array}{l}\text { Customer } \\
\text { service } \\
\mathrm{t}+5(\mathrm{CS})\end{array}$ & Primary & Restaurant \\
\hline & & 861 & -.12 & .14 & Total $(\mathrm{t}+3)$ & $\begin{array}{l}\text { Profit } t+3 \\
\quad(\text { FP) }\end{array}$ & Primary & Restaurant \\
\hline & & 861 & -.07 & .14 & Total $(\mathrm{t}+3)$ & $\begin{array}{l}\text { Profit } t+4 \\
\text { (FP) }\end{array}$ & Primary & Restaurant \\
\hline & & 861 & -.16 & .14 & Total $(\mathrm{t}+3)$ & $\begin{array}{l}\text { Profit } t+5 \\
\quad(\mathrm{FP})\end{array}$ & Primary & Restaurant \\
\hline & & 861 & -.15 & .15 & Total $(\mathrm{t}+4)$ & $\begin{array}{l}\text { Customer } \\
\text { service } \\
\mathrm{t}+4(\mathrm{CS})\end{array}$ & Primary & Restaurant \\
\hline & & 861 & -.14 & .15 & Total $(t+4)$ & $\begin{array}{l}\text { Customer } \\
\text { service } \\
\mathrm{t}+5(\mathrm{CS})\end{array}$ & Primary & Restaurant \\
\hline & & 861 & -.02 & .15 & Total $(t+4)$ & $\begin{array}{l}\text { Profit } t+4 \\
\quad(F P)\end{array}$ & Primary & Restaurant \\
\hline & & 861 & -.15 & .15 & Total $(\mathrm{t}+4)$ & $\begin{array}{l}\text { Profit } t+5 \\
\quad(F P)\end{array}$ & Primary & Restaurant \\
\hline & & 861 & -.15 & .14 & Total $(\mathrm{t}+5)$ & $\begin{array}{l}\text { Customer } \\
\text { service } \\
\mathrm{t}+5(\mathrm{CS})\end{array}$ & Primary & Restaurant \\
\hline & & 861 & -.18 & .14 & Total $(\mathrm{t}+5)$ & $\begin{array}{l}\text { Profit } t+5 \\
\quad \text { (FP) }\end{array}$ & Primary & Restaurant \\
\hline $\begin{array}{l}\text { Vandenberg } \\
\text { et al. (1999) }\end{array}$ & $\begin{array}{l}\text { Insurance } \\
\text { companies in the } \\
\text { United States/ } \\
\text { Canada }\end{array}$ & 49 & -.16 & .26 & Total & ROE (FP) & All & Banking \\
\hline \multirow[t]{4}{*}{$\begin{array}{l}\text { Van Jaarsveld } \\
\text { \& Yanadori } \\
(2011)\end{array}$} & $\begin{array}{l}\text { Call centers in } \\
\text { Canada }\end{array}$ & 179 & -.34 & .09 & Voluntary & $\begin{array}{l}\text { CSR } \\
\text { absenteeism } \\
\text { (EWA) }\end{array}$ & Secondary & Service \\
\hline & & 179 & .08 & .09 & Voluntary & $\begin{array}{l}\text { Call } \\
\quad \text { abandonment } \\
\text { rate }(\mathrm{CS})\end{array}$ & Secondary & Service \\
\hline & & 179 & -.07 & .09 & Voluntary & $\begin{array}{l}\text { Meeting target } \\
\text { time (Q) }\end{array}$ & Secondary & Service \\
\hline & & 179 & -.12 & .09 & Voluntary & $\begin{array}{l}\text { Average call } \\
\text { handle time } \\
\text { (Q) }\end{array}$ & Secondary & Service \\
\hline $\begin{array}{l}\text { Verburg et al. } \\
\text { (2007) }\end{array}$ & $\begin{array}{l}\text { Companies in the } \\
\text { Netherland }\end{array}$ & 140 & -.04 & .07 & Total & $\begin{array}{l}\text { CEO-rated } \\
\text { performance } \\
\text { (OP) }\end{array}$ & All & Multiple \\
\hline \multirow[t]{2}{*}{$\begin{array}{l}\text { Watrous et al. } \\
\text { (2006) }\end{array}$} & $\begin{array}{l}\text { Work units adopted } \\
\text { ProMES } \\
\text { intervention }\end{array}$ & 53 & -.19 & .49 & Total & $\begin{array}{l}\text { Performance } \\
\text { improvement } \\
\text { (OP) }\end{array}$ & All & Multiple \\
\hline & & 53 & -.37 & .23 & Total & $\begin{array}{l}\text { Performance } \\
\text { improvement } \\
\text { (OP) }\end{array}$ & Primary & Multiple \\
\hline
\end{tabular}

(Appendices continue) 
Appendix A (continued)

\begin{tabular}{|c|c|c|c|c|c|c|c|c|}
\hline Article $^{a}$ & Sample & $\begin{array}{l}\text { Sample } \\
\text { size }\end{array}$ & Correlation & $\begin{array}{l}\text { Turnover } \\
\text { rates }\end{array}$ & $\begin{array}{l}\text { Turnover } \\
\text { type }^{b}\end{array}$ & $\begin{array}{l}\text { Performance } \\
\text { dimensions }\end{array}$ & $\begin{array}{l}\text { Employment } \\
\text { system }\end{array}$ & Industry \\
\hline \multirow[t]{4}{*}{ Way (2002) } & $\begin{array}{l}\text { Establishments in } \\
\text { the United States }\end{array}$ & 386 & -.09 & & Total & $\begin{array}{l}\text { Labor } \\
\text { productivity } \\
\text { (WP) }\end{array}$ & All & Multiple \\
\hline & & 386 & -.09 & & Voluntary & $\begin{array}{l}\text { Labor } \\
\text { productivity } \\
\text { (WP) }\end{array}$ & All & Multiple \\
\hline & & 386 & -.09 & & Total & $\begin{array}{l}\text { Capital } \\
\text { intensity } \\
\text { (FP) }\end{array}$ & All & Multiple \\
\hline & & 386 & -.13 & & Voluntary & $\begin{array}{l}\text { Capital } \\
\text { intensity } \\
\text { (FP) }\end{array}$ & All & Multiple \\
\hline \multirow[t]{3}{*}{$\begin{array}{l}\text { Wiersema \& } \\
\text { Bantel (1993) }\end{array}$} & $\begin{array}{l}\text { Large } \\
\text { manufacturing } \\
\text { companies in the } \\
\text { United States }\end{array}$ & 85 & -.25 & .09 & Total & ROA (FP) & $\begin{array}{l}\text { Executives } \\
\text { (second- } \\
\text { tier) }\end{array}$ & Manufacturing \\
\hline & & 85 & -.11 & .24 & Total & ROA (FP) & $\begin{array}{l}\text { Executives } \\
\text { (top-tier) }\end{array}$ & Manufacturing \\
\hline & & 85 & -.22 & .20 & Total & ROA (FP) & Executives & Manufacturing \\
\hline $\begin{array}{l}\text { Wiersema \& } \\
\text { Bird (1993) }\end{array}$ & Japanese companies & 40 & -.02 & .64 & Total & $\begin{array}{l}\text { Relative ROE } \\
\text { (FP) }\end{array}$ & Executives & Multiple \\
\hline \multirow[t]{2}{*}{$\begin{array}{l}\text { Yanadori \& } \\
\text { Kato (2007) }\end{array}$} & $\begin{array}{l}\text { Japanese publicly } \\
\text { traded, private } \\
\text { firms }\end{array}$ & 330 & -.10 & .06 & Voluntary & $\begin{array}{l}\text { Productivity } \\
2002 \text { (WP) }\end{array}$ & All & Multiple \\
\hline & & 301 & -.04 & .05 & Voluntary & $\begin{array}{l}\text { Productivity } \\
2003 \text { (WP) }\end{array}$ & All & Multiple \\
\hline $\begin{array}{l}\text { Yanadori \& } \\
\text { Kato (2009) }\end{array}$ & $\begin{array}{l}\text { Publicly traded } \\
\text { Japanese } \\
\text { companies }\end{array}$ & 266 & -.06 & .06 & Voluntary & $\mathrm{ROA}(\mathrm{FP})$ & All & Multiple \\
\hline \multirow[t]{2}{*}{$\begin{array}{l}\text { Zatzick \& } \\
\text { Iverson } \\
\text { (2006) }\end{array}$} & $\begin{array}{l}\text { Workplace and } \\
\text { employee survey }\end{array}$ & 3,044 & -.14 & .08 & Executive & $\begin{array}{l}\text { Revenue } \\
\text { minus } \\
\text { expense } \\
2001(\mathrm{FP})\end{array}$ & All & Multiple \\
\hline & & 2,942 & -.13 & .08 & Executive & $\begin{array}{l}\text { Revenue } \\
\text { minus } \\
\text { expense } \\
2002(\mathrm{FP}) \\
\text { Combined } \\
\text { with } 2001\end{array}$ & All & Multiple \\
\hline \multirow[t]{3}{*}{ Zheng (2009) } & Asia Pacific MNCs & 281 & .13 & .02 & Voluntary & $\begin{array}{l}\text { Firm growth } \\
\text { (OP) }\end{array}$ & All & Multiple \\
\hline & & 281 & -.01 & .02 & Voluntary & $\begin{array}{l}\text { Productivity } \\
\text { (OP) }\end{array}$ & All & Multiple \\
\hline & & 281 & .12 & .02 & Voluntary & $\begin{array}{l}\text { Service } \\
\text { capacity } \\
\text { (OP) }\end{array}$ & All & Multiple \\
\hline
\end{tabular}

Note. $\mathrm{HR}=$ human resources; IDA $=$ Integrated Database for Labor Market Research; NETS $=$ National Establishment Time-Series; $\mathrm{CRSP}=\mathrm{Center}$ for Research in Security Price; ICU = intensive-care unit; EU = European Union; ProMES = Productivity Measurement and Enhancement System; MNC = MultiNational Company; WP = workforce productivity; FP = financial performance; $\mathrm{Q}=$ quality; IT = information technology; CS = customer satisfaction; $\mathrm{OP}=$ overall performance; EWA $=$ employee work attitudes; ROA $=$ return on assets; GRATE $=$ Gross Rate of Return on Capital; TAAS $=$ Texas Assessment of Academic Skills; ROE = Return on Equity; ROI = return on investment; RIF = reduction-in-force; SR = safety-related; CSR = Customer Service Representative; $\mathrm{CEO}=$ chief executive officer.

${ }^{a}$ Complete references can be found in the reference section. ${ }^{\mathrm{b}}$ Numbers in parentheses indicate the timing that the variable is measured; $\mathrm{t}=$ time. 


\section{Appendix B}

\section{References of the Studies Considered but Excluded}

\section{No Empirical Data (25)}

Abelson, M. A., \& Baysinger, B. D. (1984). Optimal and dysfunctional turnover: Toward an organizational level model. Academy of Management Review, 9, 331-341.

Bhattacharya, M., \& Wright, P. M. (2005). Managing human assets in an uncertain world: Applying real options theory to HRM. International Journal of Human Resource Management, 16, 929-948.

Bruton, G. D., Kells, J. K., \& Shook, C. L. (1996). Downsizing the firm: Answering the strategic questions. Academy of Management Executive, $10,38-45$

Budros, A. (1999). A conceptual framework for analyzing why organizations downsize. Organization Science, 10, 69-82.

Cameron, K. S. (1994). Strategies for successful organizational downsizing. Human Resource Management, 33, 189-211.

Cascio, W. F. (1993). Downsizing: What do we know? What have we learned? Academy of Management Executive, 7, 95-104.

Cascio, W. F. (2006). The economic impact of employee behaviors on organizational performance. California Management Review, 48, 41-59.

Daily, C. M. (1994). Bankruptcy in strategic studies: Past and promise. Journal of Management, 20, 263-295.

Dalton, D. R., \& Todor, W. D. (1979). Turnover turned over: An expanded and positive perspective. Academy of Management Review, 4, 225-235.

Datta, D. K., Guthrie, J. P., Basuil, D., \& Pandey, A. (2010). Causes and effects of employee downsizing: A review and synthesis. Journal of Management, 36, 281-248.

Dess, G. G., \& Shaw, J. D. (2001). Voluntary turnover, social capital, and organizational performance. Academy of Management Review, 26, 446-456.

De Winne, S., Stynen, D., \& Sels, C. G. (2008). Is meer personeel in beweging beter? Gedrag \& Organisatie, 21, 344-364.

Freeman, S. J., \& Cameron, K. S. (1993). Organizational downsizing: A convergence and reorientation framework. Organization Science, 4, 10-29.

Hayes, L. J., O’Brien-Pallas, L., Duffield, C., Shamian, J., Buchan, J., Hughes, F., . . . Stone, P. W. (2006). Nurse turnover: A literature review. International Journal of Nursing Studies, 43, 237-263.

Ichniowski, C., Kochan, T. A., Levine, D., Olson, C., \& Strauss, G. (1996). What works at work: Overview and assessment. Industrial Relations, 35, 299-333.

Jones, C. B. (2004). The costs of nurse turnover: Part 1: An economic perspective. Journal of Nursing Administration, 34, 562-570.

Kesner, I. F., \& Sebora, T. C. (1994). Executive succession: Past, present \& future. Journal of Management, 20, 327-372.

Kim, T., \& Rhee, M. (2009). Exploration and exploitation: Internal variety and environmental dynamism. Strategic Organization, 7, 11-41.

Kinnie, N., Hutchinson, S., \& Purcell, J. (2000). "Fun and surveillance": The paradox of high commitment management in call centres. International Journal of Human Resource Management, 11, 967-985.

March, J. G. (1991). Exploration and exploitation in organizational learning. Organization Science, 2, 71-87.

McKinley, W., Zhao, J., \& Rust, K. G. (2000). A sociocognitive interpretation of organizational downsizing. Academy of Management Review, $25,227-243$

Osterman, P. (1987). Turnover, employment security, and the performance of the firm. In M. Kleiner (Ed.), Human resources and the performance of the firm (pp. 275-317). Madison, WI: Industrial Relations Research Association.

Price, J. L. (1989). The impact of turnover on the organization. Work and Occupations, 16, 461-473.
Price, J. L. (2001). Reflections on the determinants of voluntary turnover International Journal of Manpower, 22, 600-624.

Staw, B. M. (1980). The consequences of turnover. Journal of Occupational Behaviour, 1, 253-273.

\section{Turnover Is Not Measured as Rates (46)}

Ahmadjian, C. L., \& Robinson, P. (2001). Safety in numbers: Downsizing and the deinstitutionalization of permanent employment in Japan. Administrative Science Quarterly, 46, 622-654.

Amabile, T. M., \& Conti, R. (1999). Changes in the work environment for creativity during downsizing. Academy of Management Journal, 42, 630-640.

Aragón-Sánchez, A., Barba-Aragón, I., \& Sanz-Valle, R. (2003). Effects of training on business results. International Journal of Human Resource Management, 14, 956-980.

Argote, L., Insko, C. A., Yovetich, N., \& Romero, A. (1995). Group learning curves: The effects of turnover and task complexity on group performance. Journal of Applied Social Psychology, 25, 512-529.

Boeker, W. (1992). Power and managerial dismissal: Scapegoating at the top. Administrative Science Quarterly, 37, 400-421.

Boone, C., Van Olffen, W., Van Witteloostuijn, A., \& De Brabander, B. (2004). The genesis of top management team diversity: Selective turnover among top management teams in Dutch newspaper publishing, 1970-94. Academy of Management Journal, 47, 633-656.

Boswell, W. R., Boudreau, J. W., \& Tichy, J. (2005). The relationship between employee job change and job satisfaction: The honeymoonhangover effect. Journal of Applied Psychology, 90, 882-890.

Boudreau, J. W., \& Berger, C. J. (1985). Decision-theoretic utility analysis applied to employee separations and acquisitions. Journal of Applied Psychology, 70, 581-612.

Brookman, J. T., Chang, S., \& Rennie, C. G. (2007). CEO cash and stock-based compensation changes, layoff decisions, and shareholder value. Financial Review, 42, 99-119.

Budros, A. (2002). The mean and lean firm and downsizing: Causes of involuntary and voluntary downsizing strategies. Sociological Forum, 17, 307-342.

Cameron, K. S., Whetten, D. A., \& Kim, M. U. (1987). Organizational dysfunctions of decline. Academy of Management Journal, 30, 126-138.

Cannella, A. A., \& Lubatkin, M. (1993). Succession as a sociopolitical process: Internal impediments to outsider selection. Academy of Management Journal, 36, 763-793.

Cascio, W. F., Young, C. E, \& Morris, J. R. (1997). Financial consequences of employment-change decisions in major U.S. corporations. Academy of Management Journal, 40, 1175-1189.

Chalos, P., \& Chen, C. J. P. (2002). Employee downsizing strategies: Market reaction and post announcement financial performance. Journal of Business Finance \& Accounting, 29, 847-870.

Charness, G., \& Levine, D. I. (2000). When are layoffs acceptable? Evidence from a quasi-experiment. Industrial Relations and Labor Relations Review, 53, 381-400

Chatrath, A., Ramchander, S., \& Song, F. (1995). Are market perceptions of corporate layoffs changing? Economics Letters, 47, 335-342.

Dougherty, D., \& Bowman, E. H. (1995). The effects of organizational downsizing on product innovation. California Management Review, 37, $24-28$

Drazin, R., \& Rao, H. (1999). Managerial power and succession: SBU managers of mutual funds. Organization Studies, 20, 167-196. 
Farrell, M. A., \& Mavondo, F. (2005). The effect of downsizing-redesign strategies on business performance: Evidence from Australia. Asia Pacific Journal of Human Resources, 43, 98-116.

Flanagan, D. J., \& O'Shaughnessy, K. C. (2005). The effect of layoffs on firm reputation. Journal of Management, 31, 445-463.

Franz, D. R., Crawford, D., \& Dwyer, D. J. (1998). Downsizing, corporate performance, and shareholder wealth. Mid-American Journal of Business, 13, 11-19.

Hallock, K. F. (1998). Layoffs, top executive pay, and firm performance. American Economic Review, 88, 711-723.

Hill, G. C. (2009). The effect of frequent managerial turnover on organizational performance: A study of professional baseball managers. Social Science Journal, 46, 557-570.

Hollenbeck, J. R., \& Williams, C. R. (1986). Turnover functionality versus turnover frequency: A note on work attitudes and organizational effectiveness. Journal of Applied Psychology, 71, 606-611.

Hsieh, A.-T., \& Liu, L.-L. (2006). The re-examination of the relationship between employee stock ownership and voluntary employer change intention in Taiwan. International Journal of Human Resource Management, 17, 174-189.

Iverson, R. D., \& Zatzick, C. D. (2007). High-commitment work practices and downsizing harshness in Australian workplace. Industrial Relations, $46,456-480$.

Kang, J.-K., \& Shivdasani, A. (1997). Corporate restructuring during performance declines in Japan. Journal of Financial Economics, 46, 29-65.

Khilji, S. E., \& Wag, X. (2007). New evidence in an old debate: Investigating the relationship between HR satisfaction and turnover. International Business Review, 16, 377-395.

Krackhardt, D., \& Porter, L. W. (1980). The snowball effect: Turnover embedded in communication networks. Journal of Applied Psychology, 71, 50-55.

Leviatan, U. (1978). Organizational effects of managerial turnover in Kibbutz production branches. Human Relations, 31, 1001-1018.

Littler, C. R., \& Innes, P. (2004). The paradox of managerial downsizing. Organization Studies, 25, 1159-1184.

Love, E. G., \& Nohria, N. (2005). Reducing slack: The performance consequences of downsizing by large industrial firms, 1977-93. Strategic Management Journal, 26, 1087-1108.

Madill, J. J., Haines, G. H., \& Riding, A. L. (2007). Managing customer relationships: Account manager turnover and effective account management. Industrial Marketing Management, 36, 241-248.

Mittal, V., Rosen, J., \& Leana, C. (2009). A dual-driver model of retention and turnover in the direct care workforce. The Gerontologist, 49, 623-634.

Osterman, P. (2000). Work reorganization in an era of restructuring: Trends in diffusion and effects on employee welfare. Industrial and Labor Relations Review, 53, 179-196.

Perry, T., \& Shivdasani, A. (2005). Do boards affect performance? Evidence from corporate restructuring. Journal of Business, 78, 1403-1432.

Redman, T., \& Keithley, D. (1998). Downsizing goes East? Employment re-structuring in post-socialist Poland. International Journal of Human Resource Management, 9, 274-295.

Saïd, T., Le Louarn, J.-Y., \& Tremblay, M. (2007). The performance effects of major workforce reductions: Longitudinal evidence from North America. International Journal of Human Resource Management, 18, 2075-2094.

Somaya, D., Williamson, I. O., \& Lorinkova, N. (2008). Gone but not lost: The different performance impacts of employee mobility between cooperators versus competitors. Academy of Management Journal, 51, $936-953$.

Tai, T. W. C., \& Robinson, C. D. (1998). Reducing staff turnover: A case study of dialysis facilities. Health Care Management Review, 23, 21-42.

Tsai, C.-F., Wu, S.-L., Wang, H.-K., \& Huang, I.-C. (2006). An empirical research on the institutional theory of downsizing: Evidence from
MNC's subsidiary companies in Taiwan. Total Quality Management, 17, 633-654.

Wagar, T. H. (1998). Exploring the consequences of workforce reduction. Canadian Journal of Administrative Sciences, 15, 300-309.

Wayhan, V. B., \& Werner, S. (2000). The impact of workforce reductions on financial performance: A longitudinal perspective. Journal of Management, 26, 341-363.

Worrell, D. L., Davidson, W. N., \& Sharma, V. M. (1991). Layoff announcements and stockholder wealth. Academy of Management Journal, 34, 662-678.

Yu, G.-C., \& Park, J.-S. (2006). The effect of downsizing on the financial performance and employee productivity of Korean firms. International Journal of Manpower, 27, 230-250.

Zheng, C., Morrison, M., \& O'Neill, G. (2006). An empirical study of high performance HRM practices in Chinese SMEs. International Journal of Human Resource Management, 17, 1772-1803.

\section{No Organizational Performance Information (18)}

Alexander, J. A. (1988). The effects of patient care unit organization on nursing turnover. Health Care Management Review, 13, 61-72.

Bloom, J. R., Alexander, J. A., \& Nuchols, B. A. (1992). The effect of the social organization of work and the voluntary turnover rate of hospita nurses in the United States. Social Science \& Medicine, 34, 1413-1424.

Castle, N. G. (2005). Turnover begets turnover. The Gerontologist, 45, 186-195.

Castle, N. G. (2006). Measuring staff turnover in nursing homes. The Gerontologist, 46, 210-219.

Castle, N. G., Engberg, J., \& Anderson, R. A. (2007). Job satisfaction of nursing home administrators and turnover. Medical Care Research and Review, 64, 191-211.

Dewitt, R.-L. (1998). Firm, industry, and strategy influences on choice of downsizing approach. Strategic Management Journal, 19, 59-79.

Jones, C. B. (1990). Staff nurse turnover costs: Part II: Measurements and results. Journal of Nursing Administration, 20, 27-32.

Jones, C. B. (2005). The costs of nurse turnover: Part 2: Application of the nursing turnover cost calculation methodology. Journal of Nursing Ad ministration, 35, 41-49.

Jones, C. B. (2008). Revisiting nurse turnover costs: Adjusting for inflation. Journal of Nursing Administration, 38, 11-18.

Lant, T. K., Milliken, F. J., \& Batra, B. (1992). The role of managerial learning and interpretation in strategic persistence and reorientation: An empirical exploration. Strategic Management Journal, 13, 585-608.

Lee, C.-H., Hsu, M.-L., \& Lien, N.-H. (2006). The impacts of benefit plans on employee turnover: A firm-level analysis approach on Taiwanese manufacturing industry. International Journal of Human Resource Management, 17, 1951-1975.

Lewis, G. (1991). Turnover and the quiet crisis in the federal civil service. Public Administration Review, 51, 145-155.

Moen, P., Kelly, E. L., \& Hill, R. (2011). Does enhancing work-time control and flexibility reduce turnover? A naturally occurring experiment. Social Problems, 58, 69-98

O’Brien-Pallas, L., Griffin, P., Shamian, J., Buchan, J., Duffield, C., Hughes, F., . . . Stone, P. W. (2006). The impact of nurse turnover on patient, nurse, and system outcomes: A pilot study and focus for a multicenter international study. Policy, Politics, \& Nursing Practice, 7, 169-179.

Pencavel, J. H. (1972). Wages, specific training, and labor turnover in U.S manufacturing industries. International Economic Review, 13, 53-64.

Quoidbach, J., \& Hansenne, M. (2009). The impact of trait emotional intelligence on nursing team performance and cohesiveness. Journal of Professional Nursing, 25, 23-29.

Shaw, J. D., Delery, J. E., Jenkins, G. D., \& Gupta, N. (1998). An organization-level analysis of voluntary and involuntary turnover. Academy of Management Journal, 41, 511-525. 
Shaw, J. D., Dineen, B. R., Fang, R., \& Vellella, R. F. (2009). Employeeorganization exchange relationships, HRM practices, and quit rates of good and poor performers. Academy of Management Journal, 52, 10161033.

\section{No Correlation Information (46)}

Alexander, J. A., Bloom, J. R., \& Nuchols, B. A. (1994). Nursing turnover and hospital efficiency: An organization-level analysis. Industrial Relations, 33, 505-520.

Beedles, N. A., Lowery, C. M., Petty, M. M., \& Ezell, H. (2000). An examination of the relationships between turnover functionality, turnover frequency, and organizational performance. Journal of Business and Psychology, 15, 331-337.

Black, S. E., \& Lynch, L. M. (2001). How to compete: The impact of workplace practices and information technology on productivity. Review of Economics and Statistics, 83, 434-445.

Brown, C., \& Medoff, J. (1978). Trade unions in the production process. Journal of Political Economy, 86, 355-378.

Castle, N. G., \& Engberg, J. (2005). Staff turnover and quality of care in nursing homes. Medical Care, 43, 616-626.

Castle, N. G., Engberg, J., \& Men, A. (2007). Nursing home staff turnover: Impact on nursing home compare quality measures. The Gerontologist, 47, 650-661.

Chalykoff, J., Sharma, B., \& Williams, M. (1995). Managing quality for organizational effectiveness: Empirical evidence from four sawmills in Atlantic Canada. Total Quality Management, 6, 51-59.

Chen, P., Mehrotra, V., Sivakumar, R., \& Yu, W. W. (2001). Layoffs, shareholders' wealth, and corporate performance. Journal of Empirical Finance, 8, 171-199.

Cho, S., Woods, R. H., Jang, S., \& Erdem, M. (2006). Measuring the impact of human resource management practices on hospitality firms' performances. Hospitality Management, 25, 262-277.

Cho, T. S. (2006). The effects of executive turnover on top management team's environmental scanning behavior after an environmental change. Journal of Business Research, 59, 1142-1150.

Coughlan, A. T., \& Schmidt, R. M. (1985). Executive compensation, management turnover, and firm performance. Journal of Accounting and Economics, 7, 43-66.

Daily, C. M., \& Dalton, D. R. (1995). CEO and director turnover in failing firms: A illusion of change? Strategic Management Journal, 16, 393400

D'Arcimoles, C.-H. (1997). Human resource policies and company performance: A quantitative approach using longitudinal data. Organization Studies, 18, 857-874.

D’Art, D., \& Turner, T. (2004). Profit sharing, firm performance and union influence in selected European countries. Personnel Review, 33, 335350.

Davis, J. H., Schoorman, D., Mayer, R. C., \& Tan, H. H. (2000). The trusted general manager and business unit performance: Empirical evidence of a competitive advantage. Strategic Management Journal, 21, 563-576.

Dollegast, V. (2008). Collective bargaining and high-involvement management in comparative perspective: Evidence from U.S. and German call centers. Industrial Relations, 47, 284-319.

Dolton, P., \& Newson, D. (2003). The relationship between teacher turnover and school performance. London Review of Education, 1, 131140.

Donoghue, C., \& Castle, N. G. (2006). Voluntary and involuntary nursing home staff turnover. Research on Aging, 28, 454-472.

Donoghue, C., \& Castle, N. G. (2007). Organizational and environmental effects on voluntary and involuntary turnover. Health Care Management Review, 32, 360-369.

Elayan, F. A., Swales, G. S., Maris, B. A., \& Scott. J. R. (1998). Market reactions, characteristics, and the effectiveness of corporate layoffs. Journal of Business Finance \& Accounting, 25, 329-351.

Felps, W., Mitchell, T. R., Hekman, D. R., Lee, T. W., Holtom, B. C., \& Harman, W. S. (2009). Turnover contagion: How coworkers' job embeddedness and job search behaviors influence quitting. Academy of Management Journal, 52, 545-561.

Fey, C. F., Björkman, I., \& Pavlovskaya, A. (2000). The effect of human resource management practices on firm performance in Russia. International Journal of Human Resource Management, 11, 1-18.

Gilson, C., Hurd, F., \& Wagar, T. (2004). Creating a concession climate: The case of the serial downsizers. International Journal of Human Resource Management, 15, 1056-1068.

Gooderham, P., Parry, E., \& Ringdal, K. (2008). The impact of bundles of strategic human resource management practices on the performance of European firms. International Journal of Human Resource Management, 19, 2041-2056.

Guest, D. E., \& Peccei, R. (2001). Partnership at work: Mutuality and the balance of advantage. British Journal of Industrial Relations, 39, 207236.

Harrington, C., \& Swan, J. H. (2003). Nursing home staffing, turnover, and case mix. Medical Care Research and Review, 60, 366-392.

Harris, M., Tang, K. K., \& Tseng, Y. P. (2006). Employee turnover: Less is not necessarily more? In B.H. Baltagi (Ed.) Panel data econometrics, Vol. 274: Theoretical contributions and empirical applications (pp. 327-350). Amsterdam, the Netherlands: Elsevier Science.

Harter, J. K., Schmidt, F. L., \& Hayes, T. L. (2002). Business-unit-level relationship between employee satisfaction, employee engagement, and business outcomes: A meta-analysis. Journal of Applied Psychology, 87, $268-279$.

Hiller, D., Marshall, A., McColgan, P., \& Werema, S. (2007). Employee layoffs, shareholder wealth and firm performance: Evidence from the UK. Journal of Business Finance \& Accounting, 34, 467-494.

Hurley, R. F., \& Estelami, H. (2007). An exploratory study of employee turnover indicators as predictors of customer satisfaction. Journal of Service Marketing, 21, 186-199.

Ilmakunnas, P., Maliranta, M., \& Vainiomäki, J. (2005). Worker turnover and productivity growth. Applied Economics Letters, 12, 395-398.

Kacmar, K. M., Andrews, M. C., Van Rooy, D., Steilberg, C., \& Cerrone, S. (2006). Sure everyone can be replaced ... but at what cost? Turnover as a predictor of unit-level performance. Academy of Management Journal, 49, 133-144.

Kasarda, J. D. (1973). Effects of personnel turnover, employee qualifications and professional staff ratios on administrative intensity and overhead. Sociological Quarterly, 14, 350-358.

Lee, P. M. (1997). A comparative analysis of layoff announcements and stock price reactions in the United States and Japan. Strategic Management Journal, 18, 879-894.

Palmon, O., Sun, H.-L., \& Tang, A. P. (1997). Layoff announcements: Stock market impact and financial performance. Financial Management, 26, 54-68.

Plomondon, M. E., Magid, D. J., Steiner, J. F., MaWhinney, S., Gifford, B. D., Shih, S. C., ... Rumsfeld, J. S. (2007) Primary care provider turnover and quality in managed care organizations. American Journal of Managed Care, 13, 465-472.

Powers, E. T., \& Powers, N. J. (2011). Should government subsidize caregiver wages? Some evidence on worker turnover and the cost of long-term care in group homes for persons with developmental disabilities. Journal of Disability Policy Studies, 21, 195-209. 
Ramsay, H., Scholarios, D., \& Harley, B. (2000). Employees and highperformance work systems: Testing inside the black box. British Journal of Industrial Relations, 38, 501-531.

Rodríguez, J. M., \& Ventura, J. (2003). Human resource management systems and organizational performance: An analysis of the Spanish manufacturing industry. International Journal of Human Resource Management, 14, 1206-1226.

Ronfeldt, M., Lankford, H., Loeb, S., \& Wyckoff, J. (2011). How teacher turnover harms student achievement (NBER Working Paper 17176). Retrieved from http://www.nber.org/papers/w17176

Seleim, A., Ashour, A., \& Bontis, N. (2007). Human capital and organizational performance: A study of Egyptian software companies. Management Decision, 45, 789-801.

Wagner, W. G., Pfeffer, J., \& O'Reilly, C. A., III. (1984). Organizational demography and turnover in top-management groups. Administrative Science Quarterly, 29, 74-92.

Wang, D.-S., \& Shyu, C.-L. (2008). Will the strategic fit between business and HRM strategy influence HRM effectiveness and organizational performance? International Journal of Manpower, 29, 92-110.

Wood, S., \& de Menezes, L. M. (2008). Comparing perspectives on high involvement management and organizational performance across the British economy. International Journal of Human Resource Management, 19, 639-682.

Zimmerman, S., Gruber-Baldini, A. L., Hebel, J. R., Slane, P. D., \& Magaziner, J. (2002). Nursing home facility risk factors for infection and hospitalization: Importance of registered nurse turnover, administration, and social factors. Journal of the American Geriatrics Society, 50, 1987-1995.

Zimmerman, S., Sloane, P. D., Eckert, J. K., Gruber-Baldini, A. L., Morgan, L. A., Hebel, J. R., ... Chen, C. K. (2005). How good is assisted living? Findings and implications from an outcomes study. Journal of Gerontology: Social Sciences, 60B, S195-S204.

\section{Non-Unit or Organization Level Studies (6)}

Boswell, W. R., Boudreau, J. W., \& Tichy, J. (2005). The relationship between employee job change and job satisfaction: The honeymoonhangover effect. Journal of Applied Psychology, 90, 882-890.

Dalton, D. R., Krackhardt, D. M., \& Porter, L. W. (1981). Functional turnover: An empirical assessment. Journal of Applied Psychology, 66, $716-721$.

Griffeth, R. W., Hom, P. W., \& Gaertner, S. (2000). A meta-analysis of antecedents and correlates of employee turnover: Update, moderator tests, and research implications for the next millennium. Journal of Management, 26, 463-488.
Hollenbeck, J. R., \& Williams, C. R. (1986). Turnover functionality versus turnover frequency: A note on work attitudes and organizational effectiveness. Journal of Applied Psychology, 71, 606-611.

Sheridan, J. E. (1985). A catastrophe model of employee withdrawal leading to low job performance, high absenteeism, and job turnover during the first year of employment. Academy of Management Journal, $28,88-109$.

Spreitzer, G. M., \& Mishra, A. K. (2002). To stay or to go: Voluntary survivor turnover following an organizational downsizing. Journal of Organizational Behavior, 23, 707-729.

\section{Individual Chief Executive Officer (CEO) Departure (6)}

Abe, Y. (1997). Chief executive turnover and firm performance in Japan. Journal of the Japanese and International Economies, 11, 2-26.

Cao, Q., Maruping, L. M., \& Takeuchi, R. (2006). Disentangling the effects of CEO turnover and succession on organizational capabilities: A social network perspective. Organization Science, 17, 563-576.

Potter, S. J., \& Dowd, T. J. (2003). Executive turnover and the legal environment: The case of California hospitals, 1960-1995. Sociological Forum, 18, 441-464.

Puffer, S. M., \& Weintrop, J. B. (1991). Corporate performance and CEO turnover: The role of performance expectations. Administrative Science Quarterly, 36, 1-19.

Samuelson, B. A., Galbraith, C. S., \& McGuire, J. W. (1985). Organizational performance and top-management turnover. Organization Studies, 6, 275-291

Virany, B., Tushman, M. L., \& Romanelli, E. (1992). Executive succession and organization outcomes in turbulent environments: An organization learning approach. Organization Science, 3, 72-91.

\section{Same Sample Used More Than Once (2)}

Morrow, P., \& McElroy, J. (2007). Efficiency as a mediator in turnoverorganizational performance relations. Human Relations, 60, 827-849.

Sels, L., De Winne, S., Delmotte, J., Moes, J., Faems, D., \& Forrier, A. (2006). Linking HRM and small business performance: An examination of the impact of HRM intensity on the productivity and financial performance of small business. Small Business Economics, 26, 83-101.

Received June 9, 2011

Revision received September 20, 2012 Accepted September 24, 2012 